$$
\text { UNIVERSIDADE DE BRASÍLIA - UNB }
$$

FACULDADE DE ECONOMIA, ADMINISTRAÇÃO, CONTABILIDADE E CIÊNCIA DA INFORMAÇÃO E DOCUMENTAÇÃO (FACE)

ANA MARIA MALLMANN COSTI

\title{
CONTRIBUIÇÃO PARA A \\ GESTÃO FINANCEIRA DE EMPRESAS PÚBLICAS FEDERAIS SOB O ENFOQUE DO MODELO DINÂMICO
}

Brasília - DF 


\title{
CONTRIBUIÇÃO PARA A GESTÃO FINANCEIRA DE EMPRESAS PÚBLICAS FEDERAIS SOB O ENFOQUE DO MODELO DINÂMICO
}

\begin{abstract}
Monografia apresentada ao Programa de Pós-Graduação em Administração (PPGA) da Faculdade de Economia, Administração, Contabilidade e Ciência da Informação e Documentação (FACE), da Universidade de Brasília, como requisito parcial à obtenção do grau de Especialista em Orçamento e Finanças.
\end{abstract}

Orientador: Prof. - Paulo Henrique Feijó da Silva.

\section{Brasília - DF}




\section{RESUMO}

O objetivo deste trabalho é contribuir para a problemática de avaliação do desempenho financeiro das empresas públicas estatais federais controladas pelo DEST. Dentro deste escopo, buscou-se identificar o comportamento de um conjunto de empresas dos setores do comércio varejista e de transportes, e se há ligação entre os indicadores da metodologia Fleuriet e a Necessidade de Financiamento Líquido possuíam maior valor agregado do que aquelas classificadas nos tipos Insatisfatória, Ruim e Péssima. Para a formulação e obtenção dos resultados, buscou-se uma fundamentação teórica dos aspectos relativos à gestão financeira precedida de uma revisão de literatura sobre o modelo analítico utilizado por Michel Fleuriet que, através da mensuração de suas variáveis características, proporciona uma análise dinâmica da gestão e perfil financeiro das empresas, e classifica sua saúde financeira em 6 categorias. O trabalho investigativo utilizou dados de 26 empresas que compõem os setor de Demais do Setor Produtivo Estatal, controlado pelo DEST. Os resultados obtidos indicaram que a metodologia do Modelo Fleuriet é aplicável ao acompanhamento do desempenho financeiro das estatais federais.

Palavras-chave: Empresas Públicas. Gestão Financeira. Modelo Fleuriet 


\section{AGRADECIMENTO}

Ao meu orientador, Paulo Henrique Feijó da Silva, pelo apoio, presteza e solicitude.

À Prof $^{\underline{a}}$. Drạ. Maria de Fátima Bruno-Faria, por seu notável exemplo como educadora e pesquisadora.

A Prof. Dr. Eduardo Raupp pela compreensão e estímulo.

Ao representante de turma, Josimar Pereira de Souza, que nos momentos de dificuldades de conciliar as atividades profissionais com os compromissos assumidos durante o curso, atuou com um verdadeiro coaching. 
"Eu prefiro ser essa metamorfose ambulante, do que ter aquela velha opinião formada sobre tudo".

Raul Seixas. 


\section{LISTA DE QUADROS}

Quadro 1 - Elementos do Balanço Patrimonial............................................. 25

Quadro 2 - Contas Integrantes do Balanço Patrimonial................................. 26

Quadro 3 - Indicativo de Valores - positivo e negativo.................................... 34

Quadro 4 - Situações Financeiras possíveis preconizada pelo Modelo Fleuriet 73 


\section{LISTA DE GRÁFICOS}

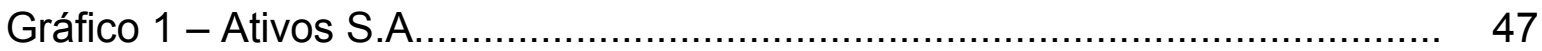

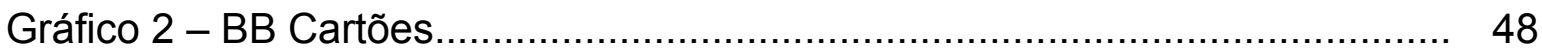

Gráfico 3 - BB Corretora............................................................... 49

Gráfico 4 - BB Turismo.................................................................. 50

Gráfico 5 - CAESMG

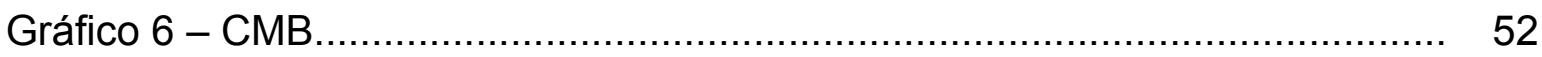

Gráfico 7 - CEAGESP...................................................................... 53

Gráfico 8 - CEASAMINAS................................................................... 54

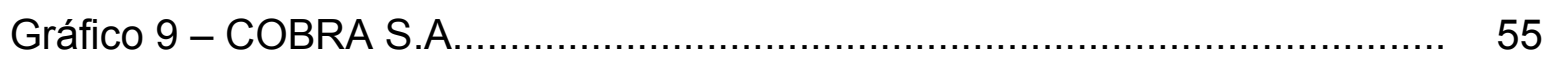

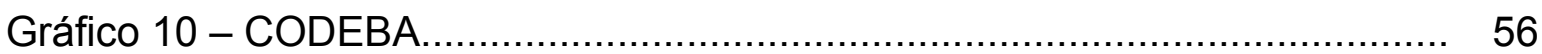

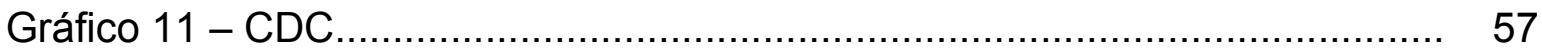

Gráfico 12 - CODESA ..................................................................... 58

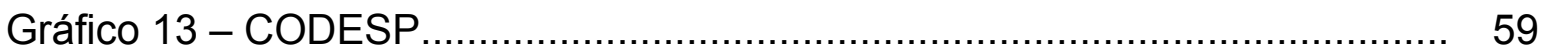

Gráfico 14 - CODOMAR ............................................................... 60

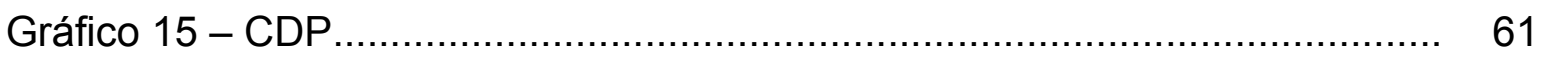

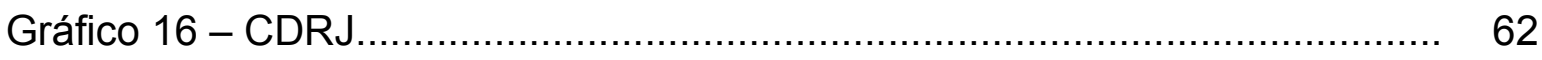

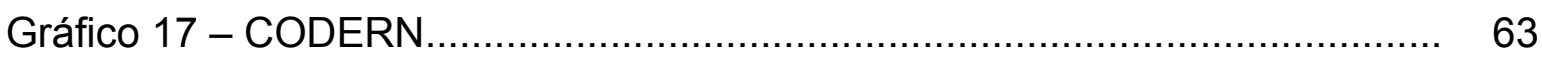

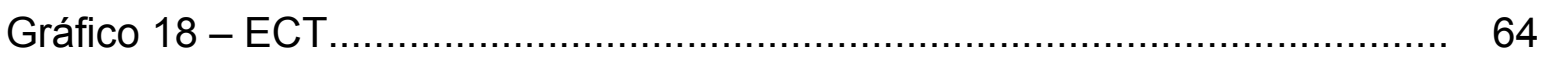

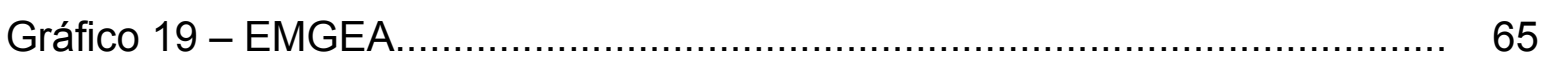

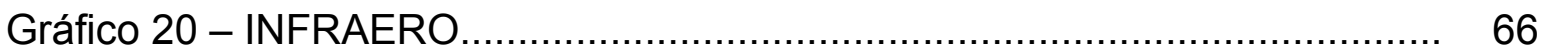

Gráfico 21 - EPE

Gráfico 22 - DATAPREV ............................................................. 68

Gráfico 23 - EMGEPRON............................................................. 69

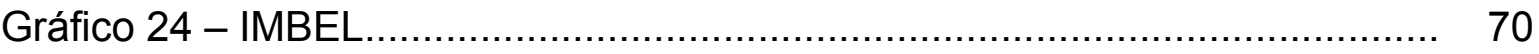

Gráfico 25 - SERPRO..................................................................... 71

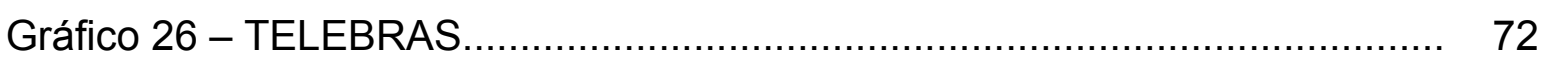




\section{SUMÁRIO}

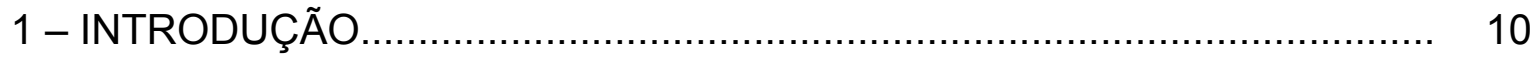

1.1 - Formulação do problema de pesquisa............................................... 13

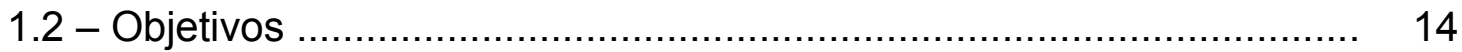

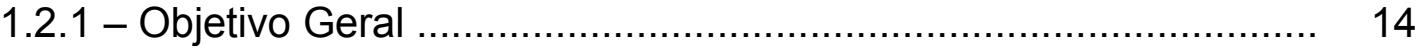

1.2.2 - Objetivos Específicos ………........................................ 15

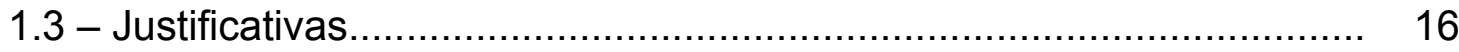

2 - REFERENCIAL TEÓRICO.................................................................. 18

2.1 - Finalidade das Empresas Públicas............................................. 18

2.2 - Sustentabilidade e eficiência das Empresas Públicas........................ 19

2.3 - Critério atual de avaliação do desempenho das Empresas Estatais... 20

2.4 - O Modelo Fleuriet........................................................................... 24

2.4.1 - Capital de Giro Líquido..................................................... 29

2.4.2 - Necessidade de Capital de Giro............................................. 31

2.4.3 - Saldo de Tesouraria.............................................................. 32

2.4.4 - As Estruturas de Balanços.................................................... 33

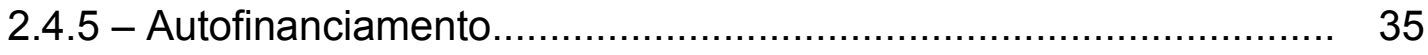

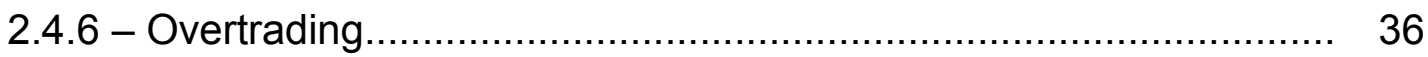

2.4.7 - O Efeito Tesoura.............................................................. 37

3 - METODOLOGIA

3.1 - Tipo de pesquisa ......................................................... 42

3.2 - Procedimentos de coleta dos dados................................................ 44

3.3 - Análise dos dados............................................................... 45

4 - APRESENTAÇÃO DOS RESULTADOS.............................................. 46

4.1 - Balanços na formatação preconizada pelo Modelo Fleuriet................ 46 
4.2 - Resultados das Empresas analisadas pelo Modelo Fleuriet

73

4.3 - Resultados primários versus Necessidade de Capital de Giro

5 - CONCLUSÃO

REFERÊNCIAS 


\section{1. - INTRODUÇÃO.}

As empresas públicas são definidas no direito administrativo moderno, como instrumentos de ação do Estado, agindo em conformidade com os princípios constitucionais ordenadores da atividade econômica e financeira.

A empresa pública é um agente econômico estando submetida ao conjunto de leis de funcionamento que definem uma economia contemporânea. Da empresa pública também se fez um agente político, na medida em que ela foi encarregada de certo número de missões dotadas de caráter social. Estas duas missões não coincidem e, muitas vezes são contraditórias para a empresa.

As empresas estatais federais são pessoas jurídicas de direito privado e estão organizadas, em sua maioria, sob a forma de sociedades de capital por ações e de empresas públicas. Encontram-se ainda, entre as subsidiárias e controladas dessas empresas, sociedades civis ou por cota de responsabilidade limitada, englobando todas as empresas em que a União, direta ou indiretamente, detenha a maioria do capital social com direito a voto. Por serem dotadas de personalidade jurídica de direito privado, estão sujeitas à Lei $\mathrm{n}^{0}$ 6.404, de 15 de dezembro 1979 (BRASIL, 1976), Lei das Sociedades Anônimas, no que se refere aos aspectos constitutivos, organizacionais, administrativos, operacionais, de relacionamento com o mercado, etc.

O Decreto-Lei $\mathrm{n}^{\circ}$ 200, de 25 de fevereiro de 1967 (BRASIL, 1967), ao tratar da organização administrativa federal, trouxe em seu bojo um conceito legal de empresas pública e sociedade de economia mista, assim definidos:

empresa pública - entidade dotada de personalidade jurídica de direito privado, com patrimônio próprio e capital exclusivo da União ou de suas entidades da Administração Indireta, criada por lei para desempenhar atividades de natureza empresarial que o governo seja levado a exercer por motivo de conveniência ou contingência administrativa, podendo tal entidade revestir-se de qualquer das formas admitidas em direito e

sociedade de economia mista - entidade dotada de personalidade de direito 
privado, criada por lei para o exercício de atividade de natureza mercantil, sob a forma de sociedade anônima, cujas ações com direito a voto pertençam, em sua maioria, à União ou à entidade de Administração indireta.

Com o tempo, as estatais, principalmente na forma de sociedades de economia mista, inicialmente vinculadas a atividades econômicas e financeiras, passaram a ser largamente utilizadas como prestadoras de serviços públicos. Passamos, assim, a ter em nosso ordenamento jurídico empresas públicas voltada para atividades econômicas (produção, circulação e consumo de bens e serviços) e outras voltadas à prestação de serviços públicos.

A Constituição da República Federativa do Brasil (CF/88), de 05 de dezembro de 1988 (BRASIL, 1988), em seu art. 165, parágrafo $5^{\circ}$, inciso II, determina que o orçamento de investimento de cada empresa em que a União, direta ou indiretamente, detenha a maioria do capital social com direito a voto, seja submetido à aprovação do Congresso Nacional. Os investimentos são os valores agregados ao ativo imobilizado e formação do ativo diferido, proveniente de imobilizações, de acordo com as determinações da Lei das Sociedades Anônimas, (BRASIL, 1976), discriminados projetos, definidos a partir das disposições e prioridades estabelecidas na Lei de Diretrizes Orçamentárias (LDO).

Para fins de controle orçamentário, as empresas estatais federais são divididas em dois grupos:

as que custeiam suas atividades com recursos próprios ou de mercado e

as que dependem de recursos do orçamento fiscal para pagar parte ou a totalidade de seus gastos correntes, especialmente com pessoal.

Para conciliar as propostas orçamentárias das empresas com os requisitos da política macroeconômica, são estabelecidos anualmente parâmetros para as unidades orçamentárias entre eles estão:

$>$ Produto Interno Bruto (PIB);

> Taxa de Crescimento Real Anual (TCRA) - estimativa;

> Taxa de Câmbio;

$>$ Índice Geral de Preços - Disponibilidade Interna (IGP-DI) e 
Política Salarial (PS).

O conjunto das setenta e duas empresas estatais federais acompanhadas pelo Ministério do Planejamento, Orçamento e Gestão (MPOG), por meio do Departamento de Coordenação e Controle das Estatais (DEST), dados constantes do relatório de execução orçamentária de 2008, fechou o ano de 2008 com desempenho 33,2 \% superior em volume de investimentos ao realizado em 2007. De um montante de R \$39,973 bilhões realizado em 2007 passou para R\$ 53,243 bilhões em 2008. Desse total, 82,2\% foram financiados com recursos das próprias estatais.

Das setenta e duas empresas abrangidas no orçamento de investimento, sendo sessenta e três do setor produtivo e nove do setor financeiro. Das empresas do setor produtivo, dezesseis pertencem ao Grupo Eletrobrás, vinte e cinco ao Grupo Petrobras e as vinte e duas restantes estão agrupadas em diversos setores da economia. Não foram computadas as entidades cujas programações constam integralmente dos orçamentos fiscal e da seguridade social nem aquelas que não programaram investimentos.

A Lei Orçamentária Anual (LOA) fixou a dotação consolidada para o orçamento de investimento de 2008, no montante de R \$ 62.122.693.446,00 (sessenta e dois bilhões, cento e vinte e dois milhões, seiscentos e noventa e três mil e quatrocentos e quarenta e seis reais), o que significou aumento de $12,8 \%$ sobre o valor da dotação final aprovada para os investimentos das empresas estatais em 2007 e de 51,1\% sobre o montante realizado naquele exercício.

Os valores de 2007 foram atualizados para preços médios de 2008 pelo IGP-DI. O montante aprovado para 2008 agregava dotações para a execução de obras ou serviços em trezentos e dezoito projetos e duzentos e setenta atividades. Com a revisão orçamentária a dotação final aprovada alcançou o montante de $\mathrm{R} \$$ 67.322.753.611,00, sendo a realização no exercício de R\$ 53.243.569.967,00. Com o objetivo de aperfeiçoar a função do Estado e potencializar os investimentos da União em benefício da sociedade, as estatais realizaram em 2008, parcela equivalente a $82,2 \%$ com recursos de geração própria. Em relação à dotação anual total, os recursos de geração própria previstos equivalem a 77,5\%. Outros recursos de longo prazo garantiram a execução de $11,2 \%$ dos investimentos efetivados, com desempenho equivalente a $81,8 \%$ da programação final.

O cenário econômico-financeiro nacional após a crise financeira mundial de 2008 ainda 
é instável. As taxas de juros brasileiras são altas e decisões de investimento de capital para o longo prazo e a administração da liquidez numa empresa requerem muito conhecimento do mercado e da própria organização como um todo. O capital, seja ele próprio ou de terceiros, não é gratuito. Ele é escasso e tem que ser remunerado. Administrar uma empresa, nesse contexto, requer uma adequação constante de ações que podem significar o sucesso ou o fracasso do empreendimento. O papel do administrador financeiro torna-se crucial. Ele tem que assegurar o capital que atenda às necessidades de financiamento do crescimento da empresa e a operação do dia-a-dia. O capital tem que estar disponível nos montantes adequados, no momento certo e ao menor custo. $\mathrm{O}$ gestor também é responsável pela criação de valor para a empresa. Embora os administradores estejam sendo pressionados cada vez mais para produzirem valor, na maioria das vezes não possuem ferramentas necessárias.

\section{1 - Formulação do problema de pesquisa.}

A empresa pública se apresenta como um agente de econômico envolvido num processo de produção, o que pressupõe financiamento, produção e comercialização. Assim, na cadeia do processo produtivo ela se relaciona com as empresas privadas estando sujeita as leis econômicas que regem os mercados. A especificidade da empresa pública decorre dos objetivos que persegue enquanto agente econômico as opções políticas definidas pelo Estado. Logo o desempenho financeiro das empresas deve então ser julgado com todos os recursos que a pesquisa e o mercado apontam como ferramentas de apoio a gestão.

Por definição, uma empresa estatal não tem a mesma eficiência que exibiria se fosse privada. Sua governança corporativa pode até aproximá-la do padrão de gestão privada, mas a lógica da empresa privada é a da maximização dos lucros, cabendo ao Estado a defesa da concorrência. Ainda que adotem estratégia semelhante, os gestores da estatal não dispõem dos mesmos incentivos. Sua lógica é a das políticas públicas, o que pode levá-la a operar sob margens de contribuição negativas, situação inaceitável em uma empresa privada.

Como a missão básica dos administradores é gerar valor para o acionista, há incentivos 
para que busquem a eficiência. A estatal brasileira incorre em custos de transação inexistentes no setor privado. Submete-se à fiscalização do Tribunal de Contas da União (TCU). Deve prestar informações adicionais às previstas na lei societária. Seus investimentos dependem de aprovação do Congresso, o que gera incertezas ausentes na empresa privada. Associado a estas responsabilidades as empresas tem autorizado de Orçamento de Investimento para 2009 R \$ 79 milhões englobando as programações de 68 empresas estatais federais, sendo 59 do setor produtivo e 9 do setor financeiro. Das empresas do setor produtivo, 15 pertencem ao Grupo Eletrobrás, 22 ao Grupo Petrobras e as 22 restantes estão agrupadas em demais empresas. Este valor é $55,3 \%$ maior que o realizado de 2008. Dos gastos realizados com investimentos em 2009, parcela equivalente a 78,7\% do total foi financiada com recursos de geração própria. Em relação à dotação anual total, os recursos de geração própria previstos equivalem a 75,2\%. Outros recursos de longo prazo garantiram a execução de $15,4 \%$ dos investimentos efetivados (equivalentes a $28,1 \%$ da programação final).

Este estudo procura aplicar o modelo Fleuriet verificando a sua relevância no contexto da análise da liquidez e solvência à luz de seus aprimoramentos incorporados, associando a perspectiva de continuidade das empresas, além de possibilitar o acompanhamento da evolução do saldo de tesouraria, visto que a saúde financeira das mesmas é de interesse de toda a sociedade.

\section{2 - Objetivos.}

\subsection{1- Objetivo Geral.}

O objetivo geral deste estudo é analisar a problemática de avaliação do desempenho financeiro das empresas públicas classificadas na categoria Demais do Setor Produtivo, de forma a contribuir para uma visão mais detalhada da gestão financeira das empresas analisadas.

Isso revela que hoje, quando estamos tratando dos resultados das estatais, são os setores 
de petróleo e energia elétrica que realmente importam e influenciam os indicadores financeiros. Não há um estudo específico para o desempenho das demais empresas, estas sempre são consideradas para análise no conjunto das sociedades anônimas. A idéia é testar se o Modelo Fleuriet possibilita uma percepção adicional segura do desempenho financeiro das empresas e se afirmativo,propor a integração às ferramentas tradicionais utilizados pelo DEST como instrumento útil para a avaliação financeira dos negócios empresarias. O problema pode ser visualizado na seguinte questão-chave: é possível trazer maior compreensão da situação financeira das empresas categorizadas como Demais SPE, além das informações contidas na Necessidade de Financiamento Líquido (NEFIL) do Programa de Dispêndios Globais (PDG) administrado pelo DEST, pela aplicação do Modelo Dinâmico.

\subsection{2 - Objetivos específicos.}

$>$ Classificar as empresas nas seis situações financeiras possíveis preconizadas pelo Modelo, a partir da comparação das varáveis Capital de Giro (CDG), Necessidade de Capital de Giro (NCG) e Saldo de Tesouraria (ST);

$>$ Demonstrar a evolução do Saldo de Tesouraria e identificar o Efeito Tesoura e

$>$ Identificar qual a contribuição do Modelo Fleuriet na gestão financeira às empresas (DSPE);

As empresas a serem estudadas atuam em diversos setores e ramos de atividades, sendo: três, no setor de armazenamento e abastecimento de produtos agrícolas; oito, no setor de administração portuária; uma, no setor de serviços postais; uma, no setor de desenvolvimento e administração da infra-estrutura de aeroportos, bem como na proteção ao vôo e segurança do tráfego aéreo; três, no setor industrial de transformação, nos segmentos de equipamentos, de insumos militares, de produção de moeda, cédulas, selos e similares, bem como de processamento de hemoderivados; e seis, no setor de serviços, como processamento de dados e gestão de ativos. 


\section{3 - Justificativas.}

As estatais surgiram como uma dinâmica de celeridade e da eficiência, as quais se tornaram instrumentos do Estado para atingir seus objetivos de forma rápida e eficaz, tal qual ocorre com uma empresa privada. Esta é a idéia que norteia as estatais em geral: equiparar o Estado às empresas privadas, possibilitando mesclar a execução de atividades econômicas com outras de interesse público por meio das empresas públicas e das sociedades de economia mista. Com o fato de serem de natureza do direito privado, não se justifica que tenham o mesmo tratamento das privadas, tampouco que suas prerrogativas se equiparem às da Administração Direta. É relevante citar que a existência das estatais só se justifica para que alcancem os objetivos colimados pelo Estado. As empresas públicas e as sociedade de economia mista, que no geral são chamadas de empresas estatais, compõem o quadro da administração indireta.

Tal como o Estado, as empresas públicas encontram-se sujeitas a todos os controles públicos necessários para a certeza e a segurança de que, ao desenvolverem suas atividades operacionais, manter-se-ão estritamente afiveladas ao cumprimento do escopo para o qual foram concebidas e atenderão aos deveres de legalidade, impessoalidade, moralidade, publicidade e eficiência, conforme disposto no Art. 37 da Constituição da República Federativa do Brasil (CF/88) (BRASIL, 1998).

Segundo, (PENNA, 1982), que tentou conceituar o termo eficiência e escreveu sabiamente que o princípio de eficiência, sustenta, concretamente, que uma configuração é eficiente quando se torna impossível melhorar as condições de vida de algumas pessoas, sem ao mesmo tempo provocar prejuízos a outros. Esta é mais uma concepção objetiva do que se entende por eficiência econômica que necessariamente empurra para o receituário de crescimento que bem administrado, chega-se ao desenvolvimento econômico que é o que a $\mathrm{CF} /$ 88, (BRASIL, 1988) preconiza.

Há que se observar também no Art. 70 da CF/88 (BRASIL, 1988) fixado que o Congresso Nacional e o controle interno de cada Poder exercerão a "fiscalização contábil, financeira, orçamentária, operacional e patrimonial da União e das entidades da administração direta e indireta, quanto à legalidade, legitimidade, economicidade", bem como sobre "aplicação das subvenções e renúncia de receitas". 
Economicidade é um aspecto da eficiência e significa a melhor satisfação do interesse público com os menores custos para a sociedade. Segundo, Moreira (2000), é um controle de meios e não de resultados. Estes últimos são examinados segundo o conceito de eficácia na ação governamental. O exame da economicidade, pois, vai além, ao avaliar se, obtidos os resultados, os meios adotados na sua consecução foram os mais econômicos.

A economicidade de determinado ato praticado é questão intimamente ligada a um outro princípio basilar do Estado de Direito: a razoabilidade. Este, segundo Barroso (2001), é um parâmetro de valoração dos atos do Poder Público para aferir se eles estão informados pelo valor superior inerente a todo ordenamento jurídico a justiça. Por outro lado, Torres (1991) explica que o conceito de economicidade, originário da linguagem dos economistas, corresponde, no discurso jurídico, ao de justiça.

O controle da economicidade, portanto, deve ser inspirado nas idéias de adequação dos meios utilizados aos fins pretendidos, da necessidade da medida adotada e, em especial, da proporcionalidade entre o custo e o benefício obtido por meio do ato examinado. Tendo a eficiência e a economicidade como mote justifica-se plenamente analisar as empresas públicas, classificadas como Outras do Setor Produtivo Estatal sejam também observadas pelos seus resultados financeiros e pelo papel dos seus investimentos para a macroeconomia. 


\section{2. - Referencial Teórico.}

Este trabalho foi construído em três etapas, com o objetivo de contribuição aos atuais métodos de avaliação de desempenho utilizados e oferecer uma análise adicional sobre as Demais Empresas do Setor Produtivo, que serão desenvolvidos nos seguintes tópicos: finalidade das empresas públicas, o critério atual de avaliação do desempenho das empresas estatais aplicado pelo DEST e uma análise descritiva da posição financeira de negócios, incorporando seus principais aprimoramentos surgidos nesses últimos anos.

\section{1 - Finalidade das Empresas Públicas.}

Segundo, André (1990) a melhor forma de sustentar a finalidade da empresa pública é demonstrá-la apresentando os seus objetivos, resultados econômicos e sociais. É recomendável que a avaliação de empresas públicas se realize observando:

$>$ a eficácia entendida como o volume e a qualidade dos bens e serviços que ela fornece à sociedade e a extensão do seu atendimento ao interesse social ;

a eficiência, entendida como a capacidade de produzir, com qualidade, fazendo uso, o mais parcimonioso possível, do conjunto, de insumos necessários a essa produção;

$>$ os resultados econômicos considerando os custos e as receita e

$>$ o desempenho financeiro e a contribuição dos cofres públicos para a sua sustentação, verificando o ônus do endividamento da empresa sobre o orçamento da União e a estratégia de captação de recursos para investimentos.

O processo de definição do Programa de Dispêndios Globais (PDG), tanto na fase de 
proposição pelas empresas quanto no momento de análise e consolidação no âmbito da DEST, é pautado em parâmetros estabelecidos pela equipe econômica e compatibilizado com as metas de superávit primário do setor público. A inclusão das estatais na apuração da Necessidade de Financiamento do Setor Público (NFSP), como lembra Biasoto Jr. (2006), é uma criação do Fundo Mundial Internacional (FMI) para os países menos desenvolvidos e derivada de uma postura política decorrente do chamado Consenso de Washington.

Segundo, Gobetti (2007), declara que é possível identificar uma segunda fonte de contribuição das estatais para o resultado primário, configurada pelos pagamentos que as estatais realizam ao Tesouro a título de dividendos e compensações financeiras, notadamente royalties e Participação Especial do Petróleo (PE). O quanto do superávit primário do setor público pode ser explicado pela contribuição das estatais. Incluindo além dos dividendos e compensações financeiras, computar também outros pagamentos de tributos e encargos parafiscais executados pelas estatais, que contribuem para o superavit primário.

A meta de superávit primário das estatais não inclui o setor financeiro e é sempre definida previamente à elaboração e aprovação do PDG, de modo que o programa seja perfeitamente adequado à Necessidade de Financiamento do Setor Público (NFSP). As despesas são periodicamente avaliadas pela DEST e, em casos de necessidade decorrente de contingências relacionadas a alterações nas premissas macroeconômicas, as empresas são chamadas para uma revisão de suas metas.

\section{2 - Sustentabilidade e Eficiência das Empresas Públicas.}

De acordo, Rees (1979), a idéia de eficiência econômica da empresa pública se dividia em dois conceitos: o de eficiência administrativa e tecnológica, pelo qual a empresa reduz seus custos internos, e a eficiência alocativa que é um conceito derivado da teoria da Economia do Bem Estar e diz respeito, no nível mais geral, à alocação global de recursos numa economia. A eficiência alocativa implica eficiência

administrativa e tecnológica, mas a recíproca não é verdadeira, como o próprio caso do monopólio privado maximizando lucros pode demonstrar, uma vez que mesmo com eficiência 
administrativa e tecnológica a tendência é seu nível de produção situar-se abaixo do que os consumidores estariam desejando. Por outro lado, uma alocação de recursos eficiente, continua Rees (1979), deve ser tal que não exista qualquer ineficiência tecnológica, não podendo, por outro lado, coexistir ineficiência alocativa com eficiência tecnológica no caso de uma empresa pública, ou seja: a estatal obtendo sua produção ao menor custo face às condições vigentes, não pode estar submetida a uma política de preços inapropriada, como por exemplo a cobrança de tarifas administradas pelo governo inferiores ao seu custo marginal.

A escolha pelo modelo Fleuriet (FLEURIET; KEHDY; BLANC, 2003), para a análise do desempenho financeiro das empresas baseia-se em vários estudos entre eles o decisivo foi abordado por Braga e Oliveira (2002).

E finalmente, o principal alicerce para a concretização deste estudo está em Lobato (2007) que afirma ser de fundamental importância para o governo melhorar a gestão das empresas estatais buscando um estudo aprofundado do desempenho das empresas estatais que abranja os benefícios sociais e ambientais possibilitando aumentar a visibilidade dos resultados obtidos e respaldar os planos de investimentos.

\section{3 - Critério atual de avaliação do desempenho das empresas estatais.}

As estatais foram incluídas no déficit ou superávit primário do setor público em 1983, por uma exigência do Fundo Monetário Internacional (FMI). Nesse período as estatais foram utilizadas pelo Governo para financiar a dívida. A importância da meta de superávit primário retomou a importância após a implantação do Plano Real e de um novo acordo com o FMI feito em novembro de 1998 que exigia do Governo brasileiro um superávit primário entre 3 a 4\% do PIB. Apesar do acordo com FMI ter vencido em março de 2005, o Governo Lula continua com a política exigindo a contribuição das empresas estatais para o atendimento das metas de superávit primário. Para 2007 a 2010 a meta de superávit primário exigida das empresas estatais será de $0,7 \%$ PIB, em torno de R $\$ 16$ bilhões de reais. Essa meta deverá levar ao país ao déficit nominal zero, ou seja, o déficit do Governo incluindo o pagamento dos juros nominais seria reduzido a zero. 
A Lei $n^{\circ}$ 10.683, de 13 de agosto de 2004 (BRASIL, 2004) diz que é competência do Ministério do Planejamento, Orçamento e Gestão a formulação de diretrizes e controle da gestão das empresas estatais. Efetivamente, o Governo controla os investimentos e a política salarial das empresas estatais. Esse controle está diretamente relacionado com a preocupação do Governo com superávit primário. Além do superávit primário e investimentos, o Governo também controla os gastos com os funcionários e as contratações das empresas estatais, por meio da Lei $n^{0} 8.666$, de 21 de junho de 1993. (BRASIL, 1993).

O Orçamento Geral da União é divido em três partes: orçamento da seguridade social, orçamento fiscal, que inclui também as empresas que recebem recursos da União (dependentes) e o orçamento de investimentos das empresas estatais com o Programa de Dispêndios Globais (PDG).Este é aprovado através de decreto pelo Presidente da República e o DEST é o responsável pela consolidação das propostas de dispêndio gerando o PDG.

O Orçamento Anual de Investimento está estruturado da mesma forma do PPA, em programas e ações (projetos de investimento). No OAI encontra-se o orçamento de todos os projetos de investimento que serão realizados pelas empresas estatais no ano seguinte. O PDG apresenta a discriminação das origens e aplicações de recursos, a demonstração do fluxo de caixa, compatibilização econômica-financeira e as necessidades de financiamento líquido, conforme padrões e formatação definidos pelo Governo Federal. No PDG todo o OAI da empresa é dado numa linha.

O PDG é composto dos seguintes demonstrativos:

Discriminação das Origens de Recursos - DICOR : registro econômico de todas as receitas e recursos, independentemente de sua natureza e origem, destinados à cobertura dos dispêndios globais em um determinado período, segundo o conceito de competência;

Discriminação das Aplicações dos Recursos (DICAR): registro de todos os dispêndios, exceto os relativos à correção monetária, depreciação e amortização de ativos, segundo o conceito de competência;

Demonstração do Fluxo de Caixa (DFLUX): registro de toda movimentação de caixa da empresa num determinado período de tempo; 
Fechamento do fluxo de caixa (FEFCx): compatibilização dos valores econômicos constantes dos demonstrativos DICOR e DICAR com os valores financeiros apresentados na DFLUX e

A Necessidade de Financiamento Líquido (NEFIL) - acima da linha - é o principal indicador macroeconômico para a aferição do desempenho da empresa, em termos financeiros, uma vez que demonstra se a geração de receitas próprias é suficiente para a cobertura da totalidade de suas despesas, em determinado período. O resultado da NEFIL, apurado pelo DEST, obedece aos seguintes conceitos:

- o Resultado Nominal - incorpora os efeitos monetários decorrentes da inflação nas receitas e despesas;

- o Resultado Operacional - exclui os efeitos da correção monetária das receitas e despesas e mantém as receitas e despesas financeiras (juros ativos e passivos) e

- o Resultado Primário - exclui os efeitos das receitas e despesas financeiras (juros).

Segundo, Noble (1997), ressalta que as principais críticas aos sistemas de medição de desempenho tradicionais são:

Deixam passar algumas medidas; já que os relatórios financeiros são usualmente fechados mensalmente, ao passo que existem decisões que são tomadas em um ou dois meses prioritários. Os resultados financeiros são, em algumas vezes, muito velhos para serem úteis;

Tentam quantificar o desempenho e outros esforços de melhoria somente em termos financeiros. Muitos destes esforços são de difícil mensuração possuindo significantes impactos no sucesso global, como redução de tempos e fidelidade ao esquema de produção e 
Possuem um formato predeterminado. Todo registro é inflexível e ignora o fato de que cada departamento ou agente tem suas únicas e próprias características, prioridades e contribuições. Outras críticas apresentadas às limitações dos sistemas tradicionais de medição de desempenho são apresentadas por Neely (1998):

- Focam em resultados de curto prazo;

- Faltam informações relacionadas a qualidade, entrega e flexibilidade, além de não apresentarem um foco estratégico;

- Encorajam otimizações locais, por exemplo, produzir estoques para manter máquinas e operadores produtivos;

- Incentiva pouco as inovações, ao invés de buscar melhorar continuamente;

- Não conseguem traduzir métricas sobre o foco no cliente e desempenho da concorrência.

De acordo com Neely et al. (1997) sugerem um conjunto de diretrizes para a definição dos indicadores de desempenho, dentre as quais destacam-se as seguintes:

serem derivadas da estratégia, refletindo seus objetivos e metas;

serem simples e de fácil entendimento;

serem relevantes e claramente definidas;

> serem capazes de fornecer informações confiáveis e retroalimentação rápida;

$>$ terem fórmula e procedimento de coleta bem definidos e explícitos;

$>$ serem consistentes e

usarem dados, quando possível, que sejam automaticamente coletados como parte do processo. 
A análise convencional do capital de giro baseia-se na observação do comportamento do Capital Circulante Líquido (CCL), dos seus componentes, inseridos no ativo e no passivo circulantes, nos índices de liquidez (corrente, seca, imediata), além dos ciclos operacional e financeiro das empresas. De um modo geral, espera-se que uma empresa com uma boa situação de liquidez tenha um CCL positivo e índices de liquidez superiores a determinados benchmarks, que podem ser estabelecidos em bases setoriais ou extraídos de empresas similares ou de mesmo porte. É recomendável, também, observar a evolução desses indicadores ao longo do tempo, de modo a se determinarem tendências.

Mais recentemente, outros indicadores vêm sendo utilizados, tais como a duration ASSAF NETO e SILVA (2002). O dimensionamento de cada um dos itens do capital de giro é realizado desagregando-se os seus diversos componentes e tratando-os separadamente. $\mathrm{Na}$ administração do disponível, por exemplo, há o modelo de Baumol (1952), o modelo de Miller e Orr (1966) e o modelo do dia da semana (GALLINGER e HEALEY 1991). Na administração financeira dos estoques há o lote econômico de compra (WILSON 1934), estoques de segurança, curva ABC e o just-in-time, dentre outros (ASSAF NETO e SILVA 2002).

\section{4 - O Modelo Fleuriet.}

O modelo Fleuriet (FLEURIET et al 1980, 2003), introduzido no Brasil nos anos 80, pretendeu trazer uma nova metodologia para a análise do capital de giro que segundo Fleuriet, Kehdy e Blanc (2003), nasceu da necessidade de se criar um estilo gerencial brasileiro e sistemas e métodos voltados para as características da estrutura empresarial do país. Também chamado de Modelo Dinâmico, este método de análise financeira de empresas foi concebido para enfrentar um ambiente de rápido crescimento e altas taxas de inflação. Mesmo com a mudança do cenário brasileiro para a estabilidade econômica, a metodologia não perdeu sua aplicabilidade.

O Modelo é uma quebra de paradigma que veio com a mudança de enfoque de análise, 
antes feita na base contábil e estática, para uma base dinâmica, e através dos dados contábeis atuais, enxergar sua capacidade de captar recursos e investir, obtendo a partir de então retornos maiores em relação aos custos captados. Antes, muitas análises somente vislumbravam o aspecto da solvência medida pelos indicadores de liquidez (corrente, seca e geral), implicando em uma visão de que não haveria continuidade dos negócios, caso todo ativo circulante fosse transformado em dinheiro para honrar compromissos.

O balanço convencional, elaborado em conformidade com as normas estabelecidas pela Lei $\mathrm{n}^{\mathrm{o}} 6.404 / 76$, relaciona as contas que compõem as fontes e destinações de recursos como mostra o quadro 1.

\begin{tabular}{||l|l||}
\hline \multicolumn{2}{|c|}{ GRUPOS INTEGRANTES DO BALANÇO PATRIMONIAL } \\
\hline Aplicações de Recursos & Origens de Recursos \\
\hline Ativo Circulante (AC) & Passivo Circulante (PC) \\
\hline Realizável a Longo Prazo (ARLP) & Exigível a Longo Prazo (PELP) \\
\hline Ativo Permanente (AP) & Resultado de Exercícios Futuros (REF) \\
\hline & Patrimônio Líquido (PL) \\
\hline
\end{tabular}

Quadro 1. Elementos do Balanço Patrimonial.

Fonte: adaptado de Braga e Marques (1995, p.45)

Em linhas gerais, os elementos do ativo circulante caracterizam-se por constituir bens ou direitos realizáveis financeiramente, em condições normais, em prazo inferior a um ano. $\mathrm{O}$ passivo circulante, por sua vez, expressa obrigações comprometidas em igual período. Os demais ativos e passivos, e o patrimônio líquido, representam itens de natureza de prazo mais longo.

Para compreender o modelo, há a necessidade de reorganizar as contas integrantes do Balanço Patrimonial para um formato direcionado à análise, conforme apresentado no Quadro 2 


\begin{tabular}{|l|l||}
\hline \multicolumn{2}{|c|}{ CLASSIFICAÇÃO CONFORME O MODELO FLEURIET } \\
\hline Aplicações de Recursos & Origens de Recursos \\
\hline Ativo Circulante Financeiro (ACF) & Passivo Circulante Oneroso (PCO) \\
\hline Ativo Circulante Cíclico (ACC) & Passivo Circulante Cíclico (PCC) \\
\hline Ativo Não Circulante (ANC) & Passivo Não Circulante (PNC) \\
\hline
\end{tabular}

Quadro 2. Contas Integrantes do Balanço Patrimonial.

Fonte: adaptado de Braga e Marques (1995, p.55)

O modelo faz a reclassificação do Balanço Patrimonial em contas erráticas, cíclicas e não cíclicas com o objetivo de tornar a contabilidade funcional e proporcionar um enfoque sistêmico. Esta reformulação é estabelecida seguindo as seguintes premissas de Fleuriet: as contas operacionais ou cíclicas são as contas relacionadas à atividade operacional da empresa, enquanto que as contas financeiras ou erráticas não estão ligadas à sua atividade operacional. É relevante ressaltar a definição de errático, segundo o autor, “errático, do latim erraticu. Errante, vadio, aleatório, andando fora do caminho. Ou seja, implica a não-ligação dessas contas ao Ciclo Operacional da empresa" FLEURIET (2003, p.7).

$\mathrm{O}$ ativo circulante se subdivide em Ativo Circulante Financeiro (ACF) ou Errático e o Ativo Circulante Operacional (ACO) ou Cíclico. O primeiro é constituído por elementos essencialmente financeiros, como caixa, bancos, aplicações financeiras e títulos de curto prazo. De acordo com Assaf Neto e Silva (2002, p.62), este grupo "não denota, por conseguinte, qualquer comportamento preestabelecido, variando mais estritamente em função da conjuntura e do risco de maior ou menor liquidez que a empresa deseja assumir".

Por outro lado, o Ativo Circulante Operacional (ACO) ou Cíclico é composto pelas contas relacionadas às atividades operacionais da empresa, como estoques, duplicatas a receber e provisão para créditos de liquidação duvidosa, sendo influenciados pelo volume de negócios ou por características das fases do ciclo operacional, como prazos de estocagem ou política de prazos de venda.

Da mesma forma, o Passivo Circulante se subdivide em Passivo Circulante Financeiro 
(PCF) ou Errático e o Passivo Circulante Operacional (PCO) ou Cíclico. O PCF é composto por empréstimos, financiamentos bancários, duplicatas descontadas, parcela de curto prazo referente a empréstimos de longo prazo e dividendos. O PCO é formado pelas obrigações de curto prazo da empresa, diretamente identificáveis com seu ciclo operacional (fornecedores, salários e encargos e impostos e taxas).

As contas do Ativo Realizável a Longo Prazo e o Permanente (Investimento Fixo) compõem um grupo denominado de Ativo Permanente ou Não-Cíclico. O Passivo Permanente ou Não Cíclico é composto pelas fontes de financiamento próprias (patrimônio líquido) e de terceiros (passivo exigível a longo prazo).

Dadas as suas proporções, os grupos circulantes abrangentes itens de natureza operacional que atendem a se renovar constantemente em função da continuidade das operações rotineiras ou não operacional que surgem de decisões negociadas e não-espontâneas, sem ligação direta com as operações da empresa. Desse modo, o ativo circulante pode ser desmembrado em ativo circulante cíclico ( $\mathrm{ACC}$ ) e o ativo circulante financeiro (ACF). No primeiro segmento, encontram-se as contas associadas à atividade operacional, como, por exemplo, duplicatas a receber provenientes das vendas, provisão para créditos de liquidação duvidosa, adiantamentos a empregados, estoques de matérias-primas, material administrativo, provisão para ajuste a valor de mercado, impostos, seguros e aluguéis antecipados. Já no ACF distribuem-se as contas fundo fixo de caixa, bancos, conta movimento, aplicações financeiras de curtíssimo prazo, títulos e valores mobiliários, dividendos.

No lado do passivo circulante, por seu turno, identificam-se o passivo circulante cíclico (PCC) e o passivo circulante oneroso (PCO). O primeiro abrange as contas decorrentes das atividades operacionais espontâneas, impostos a recolher, salários e encargos sociais a pagar, participações de empregados a pagar. No segundo grupo, ficam as contas resultantes, usualmente de negociações especificas, como financiamentos bancários de curto prazo, impostos, dividendos a pagar, dívidas de coligadas, participações estatutárias, adiantamentos de câmbio.

Os outros grupos patrimoniais do ativo e passivo foram agrupados como ativos nãocirculantes (ANC) representa a soma do Realizável a Longo Prazo (RLP) ao Ativo Permanente (AP) e passivos não circulantes (PNC), que engloba o passivo exigível a longo prazo (PELP), resultado de exercícios futuros (REF) e o patrimônio líquido (PL). No primeiro ficam os itens 
geradores de produto, enquanto no outro, as fontes normais de recursos de longo prazo disponíveis.

Todavia, podem ocorrer dificuldades no tocante à classificação de determinadas contas. Por exemplo, as contas a receber em prazo inferior a um ano oriundas da alienação de ativo imobilizado ou investimento permanente, integrantes do $\mathrm{AC}$, não se enquadram no ativo circulante cíclico (ACC) e no ACF. Os dividendos a pagar e o imposto de renda a recolher, que compõem o passivo circulante (PC), também não se identificam de maneira direta ao PCC e ao PCO. Ainda assim, por serem suas participações relativas pouco expressivas em condições normais, entendeu-se ser mais adequada a sua inclusão nos segmentos cíclicos e não-cíclicos, respectivamente.

As fontes espontâneas, por seu lado, englobam o passivo circulante cíclico e o passivo exigível a longo prazo não financeiro como adiantamentos de clientes por produção de bens ou prestação de serviços por empreitada. Participam também dessas fontes as obrigações frente a coligadas derivadas de antecipações de compras.

Da reformulação das contas contábeis e da reclassificação em rubricas conforme sua relação com as operações da empresa, o Modelo propõe a evidenciação através do enfoque dinâmico das varáveis Capital Circulante Líquido (CCL), Necessidade de Capital de Giro (NCG) e Saldo de Tesouraria (ST), estes três conceitos básicos estruturam o modelo.

$>$ Capital de Giro (CDG);

$>$ Necessidade de Capital de Giro (NCG) e

$>$ Saldo de Tesouraria (ST)

\section{- $C D G-N C G=S T$}

Os três conceitos são instrumentos poderosos na gestão financeira. Para aprofundar-se nesses conceitos, primeiramente tem-se que entender como funciona uma empresa e como ela é dependente do tempo, insumo importante num ambiente competitivo. Segundo Brasil e Brasil (2002), o Ciclo Econômico e Financeiro de uma empresa reflete a influência do tempo em suas operações. $\mathrm{O}$ ciclo econômico começa com as compras de matérias-primas e termina com a venda dos produtos ou serviços acabados ou entregues. $\mathrm{O}$ ciclo financeiro começa com o 
pagamento dos fornecedores e termina com o recebimento dos clientes. Existe entre os dois ciclos uma defasagem. Quando, no ciclo financeiro, as saídas de caixa ocorrem antes das entradas de caixa, a operação da empresa cria uma necessidade de aplicação permanente em fundos, denominada de Necessidade de Capital de Giro (NCG). O Ciclo Financeiro, de uma forma geral, é dado pela fórmula abaixo, onde PME é Prazo médio de rotação de estoques, PMR é Prazo médio de recebimento das Contas a Receber e PMP é Prazo médio de pagamento das Contas a Pagar:

$$
\text { - } C F=P M E+P M R-P M P
$$

O ciclo financeiro é medido, em termos relativos, pela expressão:

\section{- CF $=$ NCG $x$ dias do período considerado.}

A partir da reclassificação das demonstrações financeiras, realizada pelo Modelo Fleuriet, mais especificamente do balanço patrimonial, três variáveis relevantes estão relacionadas à gestão financeira da empresa, e que formulam o modelo funcional dinâmico do balanço patrimonial.

Segundo o autor do modelo, são conceitos econômico-financeiros, ao contrário do conceito do Capital Circulante Líquido (CCL), que é uma definição legal.

Segundo Assaf Neto e Silva (2002, p.63), "quando a atividade operacional da empresa criar um fluxo um fluxo de saídas de caixa mais rápido que o da entrada (os pagamentos dos fatores de produção ocorrem antes ao recebimento da venda, por exemplo), identifica-se claramente uma necessidade permanente de investimento em seu giro, que é apurada pela diferença entre os ativos e passivos cíclicos".

\subsection{1 - Capital de Giro Líquido (CGL).}

O Capital de Giro possui o mesmo valor que o Capital de Giro Líquido, definido no sentido financeiro clássico como a diferença entre o Ativo e o Passivo circulantes. Somente seu 
cálculo é realizado de maneira diferente. Constitui-se numa fonte de fundos permanente utilizada para financiar a NCG da empresa (FLEURIET, 1980, p. 17-18). O Capital de Giro Líquido ou Capital Circulante Líquido (CCL), pode ser obtido a partir dos grupos patrimoniais de curto prazo, ou de longo prazo. O CCL pode ser calculado pelas seguintes expressões matemáticas:

- CCL = ATIVO CIRCULANTE - PASSIVO CIRCULANTE

Em situações usuais o CCL significa um valor positivo, ou seja, os recursos investidos no AC que ultrapassaram o total das fontes de financiamento de curto prazo (PC) foram financiados por itens de longo prazo (PNC). Pelo lado inverso, CCL negativo significa que fontes de recursos excedentes de curto prazo estão financiando elementos de longo prazo ou, do outro ponto de vista, as origens de longo prazo são insuficientes para financiar as aplicações de recursos de longo prazo. Esta condição, se mantida por longo período, e dependendo da estrutura financeira da empresa, pode repercutir na insolvência do empreendimento.(BRAGA, MARQUES, 1995, p. 54).

Segundo BRAGA e MARQUES (1995, p. 54), no modelo Fleuriet, o comportamento do CCL pode ser melhor avaliado com base na decomposição dos grupos circulantes em seus respectivos segmentos.

Segundo Assaf Neto e Silva(2002, p.63), a NCG é diferente de CCL, em virtude da NCG ser composta somente por parte do ativo e passivo circulantes (somente as contas relacionadas com as operações), conforme a expressão:

\section{- NCG $=A C O-P C O$}

Ressaltam ainda que a NCG pode também ser negativa, o que evidencia um excesso de funcionamento, ou seja, as saídas de caixa ocorrem depois das entradas de caixa. Neste caso, esta situação denota que os passivos de funcionamento estão financiando mais do que os ativos circulantes operacionais, como outros elementos do ativo, ou seja, o passivo operacional tornase maior que o ativo operacional, representando fonte de fundos para a empresa.

Outro conceito que se apresenta é o Capital de Giro, que representa uma fonte de fundos 
permanente da empresa com a finalidade de financiar a sua Necessidade de Capital de Giro. O Capital de Giro corresponde ao mesmo valor do cálculo do CCL, mas feito de forma diferente, conforme podemos observar na expressão:

- $C D G=$ PASSIVO PERMANENTE - ATIVO PERMANENTE

O Capital de Giro possui uma característica de certa estabilidade ao longo do tempo, sofrendo alterações quando a empresa adquire novos investimentos, que podem ser realizados através de autofinanciamento (gerado em função das operações da empresa), por empréstimos a longo prazo ou por aumentos em dinheiro do capital.

\subsection{2 - Necessidade de Capital de Giro (NCG).}

Quando, no ciclo financeiro, as saídas de caixa ocorrem antes das entradas de caixa, a operação da empresa cria uma necessidade de aplicação permanente de fundos, que se evidencia no Balanço por uma diferença positiva entre o valor das contas cíclicas do Ativo e das contas cíclicas do Passivo. Esta aplicação permanente de fundos denomina-se Necessidade de Capital de Giro -NCG. FLEURIET(1980, p. 14).

Matematicamente, pode-se expressar a Necessidade de Capital de Giro através da fórmula:

- NCG = ATIVO CÍCLICO - PASSIVO CÍCLICO

Quando positiva, a NCG refere-se ao investimento líquido de curto prazo necessário, numa situação estática, à manutenção do atual nível da atividade operacional, que precisa ser financiado pelo Passivo Circulante Oneroso-PCO e ou pelo Passivo Não Circulante (PNC). (BRAGA, MARQUES, 1995, p. 54).

A NCG pode ser negativa, neste caso, no ciclo financeiro, as saídas de caixa ocorrem depois das entradas de caixa. O Passivo Cíclico torna-se maior do que o Ativo 
Cíclico,constituindo-se em fonte de fundos para a empresa. (FLEURIET, 1980, p. 16).A NCG é muito sensível às modificações que ocorrem no ambiente econômico em que a empresa opera. Assim, modificações como a redução de crédito de fornecedores, aumento de estoques, etc., alteram, a curto prazo, a NCG da empresa. Todavia, a NCG depende,basicamente, da natureza e do nível de atividade dos negócios da empresa. (FLEURIET, 1980,p. 15).

\subsection{3 - Saldo de Tesouraria (ST).}

O Saldo de Tesouraria é obtido pela diferença entre o ativo financeiro e o passivo financeiro (ou errático), isto é:

\section{- $T=$ ATIVO FINANCEIRO - PASSIVO FINANCEIRO}

$\mathrm{Ou}$ ainda pode ser representado pelo valor residual decorrente da diferença entre o Capital de Giro e a Necessidade de Capital de Giro, conforme a expressão abaixo:

$$
\text { - T }=C D G-N C G
$$

De acordo com Assaf Neto e Silva (2002, p.65), este saldo representa "uma reserva financeira da empresa para fazer frente a eventuais expansões da necessidade de investimento operacional em giro, principalmente aquelas de natureza sazonal”. A condição fundamental para que a empresa esteja em equilíbrio financeiros é que seu saldo de tesouraria seja positivo.

O Saldo de Tesouraria (T) pode ser obtido por meio da diferença entre os elementos erráticos(não-ligados de forma direta às operações usuais da empresa) do Ativo e Passivo de curto prazo. (BRAGA, MARQUES, 1995, p. 55).

Para ASSAF NETO (1989, p. 195) o Saldo da Tesouraria não mantém ligação direta com as atividades operacionais da empresa, mas representa uma medida de margem de segurança financeira para a mesma, pois procura medir a capacidade interna de uma empresa 
para o financiamento do crescimento da atividade operacional, sendo calculado pela seguinte fórmula:

\section{- Saldo de Tesouraria $T=C D G-N C G$}

O Saldo de Tesouraria pode sinalizar o grau de adequação da política financeira empregada pela administração. Quando positivo, indica disponibilidade de recursos para garantir a liquidez de curtíssimo prazo do empreendimento. Caso seja negativo, pode evidenciar dificuldades financeiras iminentes, em especial por ocasião da manutenção de saldos negativos sucessivos e crescentes. BRAGA, MARQUES(1995, p. 55) e FLEURIET (1980, p. 20) ainda destaca que o Saldo de Tesouraria representa um valor residual correspondente à diferença entre o Capital de Giro e a Necessidade de Capital de Giro.

Se o Capital de Giro for insuficiente para financiar a Necessidade de Capital de Giro,admitindo-se CCL $>0$ e NCG $>0$, o Saldo de Tesouraria será negativo. Neste caso, o Passivo errático será maior do que o Ativo errático, indicando que a empresa financia parte da Necessidade de Capital de Giro e/ou Ativo permanente com fundos de curto prazo,aumentando, portanto, seu risco de insolvência. Se o Saldo de Tesouraria for positivo, a empresa disporá de fundos de curto prazo que poderão, por exemplo, ser aplicados em títulos de liquidez imediata, aumentando assim a sua margem de segurança financeira. (FLEURIET, 1980, p. 21). De acordo com BRAGA e MARQUES (1995, p. 55), o relacionamento entre o CCL, NCG e T pode ser visualizado pela simples diferença entre as equações básicas de composição do AC e do PC, conforme demonstrado a seguir:

$$
\begin{aligned}
& -A C=A C C+A C F \\
& -\quad P C=P C C+P C O \\
& -\quad C C L=N C G+T
\end{aligned}
$$

\subsection{4 - As Estruturas de Balanços.}

A combinação dos três elementos que compõem a posição de curto prazo da organização(CCL, NCG e T) determina sua estrutura financeira em dado período, além de 
fornecerem uma tendência assumida para um horizonte de tempo mais dilatado e sua evolução no decorrer de exercícios sucessivos. (BRAGA, MARQUES, 1995, p. 56).

Segundo FLEURIET (1980, p. 22), o ciclo financeiro e a rentabilidade das empresas conferem a seus Balanços um aspecto particular que permite enquadrá-los em 6 tipos. Todavia, BRAGA e MARQUES (1995, p. 56) identificaram 6 (seis) situações possíveis pelo confronto dos elementos (CCL, NCG e T). Neste estudo, apresentam-se os tipos de Balanços segundo os estudos de (BRAGA, MARQUES, 1995, p. 56) evidenciados no Quadro 3:

\begin{tabular}{|c|c|c|c|l||}
\hline \hline \multicolumn{4}{|c|}{ Tipos de Estrutura e Situação Financeira Prevista } \\
\hline TIPO & CDG & NCG & T & \multicolumn{1}{c||}{ Situação } \\
\hline I & + & - & + & Excelente \\
\hline II & + & + & + & Sólida \\
\hline III & + & + & - & Insatisfatória \\
\hline IV & - & + & - & Péssima \\
\hline V & - & - & - & Muito Ruim \\
\hline VI & - & - & + & Alto Risco \\
\hline
\end{tabular}

Quadro 3. Indicativo de valores - positivo e negativo.

Fonte: adaptado de Marques e Braga (1995)

As companhias do Tipo 1 possuem uma situação financeira excelente em razão do alto nível de liquidez praticado.

O Tipo 2 caracteriza uma empresa com situação financeira sólida e, representa a posição mais usual encontrada no mundo real.

O Tipo 3 evidencia uma situação insatisfatória.

A situação financeira péssima proveniente da adoção da estrutura do Tipo 4 tem sido comum em certas companhias estatais, como as do ramo de geração de energia elétrica e de transporte ferroviário.

Na estrutura Tipo 5 a situação financeira caracteriza-se como muito ruim.

No Tipo 6 a situação de alto risco oriundo da utilização da estrutura permanecem negativos o CCL e o NCG, porém o valor deste é inferior ao do primeiro. 


\subsection{5 - Autofinanciamento.}

Para FLEURIET (1980, p. 25-26), O autofinanciamento pode ser considerado como o motor da empresa, que só pode desempenhar convenientemente seu papel sob uma dupla condição:

obtenção de um resultado econômico suficiente para garantir as adaptações e o crescimento necessários em um contexto concorrencial e em constante evolução e

a busca de um equilíbrio financeiro permanente.

Ainda segundo o autor, o Autofinanciamento é o resultado de duas categorias de operações econômicas, quais sejam:

$>$ das operações de produção e venda que são ligadas diretamente à atividade cíclica da empresa, e que determinam seu resultado econômico e

$>$ das operações de repartição, que compreendem a distribuição e o recebimento de rendas independentes do ciclo de produção e venda, como por exemplo, o Imposto de Renda, dividendos, despesas e receitas financeiras, etc. Segundo FLEURIET (1980, p. 26), a análise das possíveis configurações entre CCL, NCG e ST evidencia que uma situação financeira sólida implica na manutenção de CCL positivo e maior do que o NCG. Desta forma, ocorrendo NCG positivo, o CCL seria suficiente para financiá-lo e ainda gerar um saldo positivo de tesouraria $(\mathrm{CCL}>0, \mathrm{NCG}>0, \mathrm{CCL}>$ NCG e ST >0).

Neste contexto a NCG necessita ser financiada de forma adequada por suas próprias atividades, ou seja, a geração de capital de giro das operações, montante divulgado na demonstração das origens e aplicações (DOAR), quase sempre a principal origem de CCL disponível às empresas, deduzida a fatia dos dividendos propostos. (BRAGA, MARQUES, 1995, p. 60). O valor resultante corresponde ao Autofinanciamento (AUT) do empreendimento, 
expresso matematicamente pela fórmula a seguir:

\section{$\bullet A U T=L L-D E P . / A M O R T / E X-D I V I D E N D O S$}

Onde:

$\checkmark$ Lucro Líquido = lucro líquido apresentado pela empresa;

$\checkmark$ Depreciação, Amortização e Exaustão = valores contábeis que não refletem saídas de caixa (desembolsos);

$\checkmark$ Dividendos ou Juros sobre o Capital Próprio $=$ tratam-se de valores distribuídos aos acionistas que representam efetivo desembolso de caixa.

Em resumo, o Autofinanciamento representa o lucro retido pela empresa que será aplicado no sustento da Necessidade de Capital de Giro.

\subsection{6 - Overtrading.}

Em linhas gerais, overtrading significa a realização de um nível de atividade operacional e volume de vendas acima da capacidade disponível de recursos, ou seja, a administração expande os níveis de atividade e vendas do negócio sem a adequação do suporte de recursos para o financiamento do capital de giro adicional requerido. (BRAGA, MARQUES, 1995, p. 60). O crescimento das operações demanda maiores investimentos nos diversos segmentos de estoque e em duplicatas a pagar, enquanto o acréscimo ao volume de vendas pressupõe afrouxamento da política de crédito desempenhada, elevando o montante de duplicatas a receber. O aumento líquido na NCG em grau superior ao do CCL força a empresa a procurar outras origens de recursos, em especial aquelas oriundas de PCO, conduzindo-a à situação de overtrading. 


\subsection{7 - O Efeito Tesoura.}

Este efeito ocorre quando a empresa financia a maior parte da NCG através de créditos de curto prazo não renováveis. Neste caso, o Saldo de Tesouraria se apresenta negativo e crescendo, em valor absoluto, proporcionalmente mais do que a NCG. (FLEURIET, 1980, p. 46).

Ele acontece quando existe uma defasagem entre o gradiente do aumento da Necessidade de Capital de Giro e o correspondente aumento dos fatores de financiamento dessa necessidade, por efeito do crescimento e da inflação. Uma expansão no nível de vendas implica na variação da Necessidade de Capital de Giro, do Capital de Giro e do Saldo de Tesouraria. Quando há um expressivo crescimento das vendas não acompanhado de recursos de longo prazo (CDG), para cobrir a Necessidade de Capital de Giro, a empresa passa a utilizar créditos onerosos de curto prazo, gerando uma Tesouraria negativa para financiar a Necessidade de Capital de Giro. Uma particularidade do Efeito Tesoura é o verdade, que significa fazer negócios em nível superior aos recursos financeiros disponíveis. Portanto, o administrador deve ficar atento a esse efeito, pois uma forte expansão no volume de atividade de uma empresa sem o devido lastro de recursos necessários para suportar esse crescimento, fará com que seja necessário a contratação de empréstimos de curto prazo, tornando a liquidez crítica e dilapidando a criação de valor da empresa.

Para eliminar o Efeito Tesoura a empresa precisar equilibrar a variação da NCG com a variação do Autofinanciamento.

A natureza e o ambiente de negócios são complexos e abrangentes, necessitando do tomador de decisões uma observação cuidadosa dos múltiplos aspectos envolvidos. "Uma decisão é um curso de ação escolhido pela pessoa, como o meio mais efetivo à sua disposição, para alcançar os objetivos pretendidos, ou seja, para resolver o problema que o incomoda". ANDRADE (2004, p. 2).Segundo Andrade (2004, p.6), a Pesquisa Operacional, que consiste na construção de um modelo para um sistema real que sirva como instrumento de análise e compreensão do comportamento desse sistema, possui, atualmente, um enfoque gerencial qualitativo, voltado para a formulação e a modelagem, ou seja, para o diagnóstico do problema. Ela é mais desenvolvida para a solução de problemas que podem ser representados por modelos 
matemáticos. Os modelos matemáticos podem ser divididos em dois grandes tipos: modelos de simulação e modelos de otimização. Os modelos de simulação dão ao analista certo grau de liberdade e flexibilidade em relação à escolha de ação mais conveniente, pois oferecem a geração e análise de alternativas. O administrador pode criar ambientes futuros possíveis e testar alternativas, procurando a melhor alternativa para a gestão.

A primeira atenção à aplicação do modelo em relação ao crescimento máximo e o efeito tesoura. Segundo Fleuriet, Kehdy e Blanc (2003, p. 44), para se evitar que uma empresa entre no efeito tesoura com o crescimento das vendas, é necessário garantir que existam recursos próprios para financiar a NCG, não utilizando empréstimos de curto prazo para isto. Esses recursos vêm do Autofinanciamento (A), que exprime o montante dos recursos líquidos gerados pela empresa e que são retidos para financiamento interno: Lucro Retido + Depreciações e Amortizações. A taxa de autofinanciamento corrente (a) é conseguida pela relação entre A/RL. Seja (b) o ciclo financeiro medido pela relação entre a NCG e a RL e (c) a taxa de crescimento da RL.

\section{Então:}

- (a > b não há problema e a restrição não se aplica): $c<[a /(b-a)]$, para $(b-a)>0$

A segunda atenção financeira é em relação ao endividamento máximo e os efeito tesoura. Como as despesas financeiras reduzem o autofinanciamento, basta colocar um limite do endividamento financeiro. A partir da condição $a /(b-a)>c$, sendo (b-a) positivo, é possível calcular o valor mínimo da taxa de autofinanciamento corrente:a $>=[\mathrm{b} \mathrm{x} \mathrm{c} /(1+\mathrm{c})]$. A taxa de autofinanciamento (a) reduzido pelas despesas financeiras não deve ficar, portanto, abaixo da relação b x c / $(1+\mathrm{c})$.Uma outra variável exógena em relação à variável de decisão RL é a taxa de crescimento sustentável da empresa, a terceira restrição do modelo. "A necessidade de novos ativos, decorrente do crescimento projetado das vendas, sobe mais rapidamente do que os aumentos de lucros retidos mais novas dívidas. Eventualmente, gera-se um déficit, surgindo a necessidade de financiamento externo" (ROSS, WESTERFIELD, JAFFE, 2002, p. 592). 
A taxa sustentável de crescimento das vendas (Tc) é dada por:

$$
\text { - Tc }=p x(1-l) x(1+L)_{-} T a-(p \times(1-l) \times(1+L)
$$

\section{Onde:}

$\checkmark$ "p” significa a margem de lucro líquido (LL/RL);

$\checkmark$ “l” significa o índice de distribuição de lucro (Dividendos/LL);

$\checkmark$ "L" significa o quociente entre o capital de terceiros e o capital próprio e

$\checkmark$ “Ta" significa o índice de necessidade de ativos (ativos sobre RL).

Em relação aos ativos e passivos cíclicos ou operacionais (PME, PMR, PMP e PMO), será adotada, como premissa, a média dos indicadores dos últimos 03 anos, compondo um Ciclo Financeiro (CF) baseado em fatos que já aconteceram e passíveis de acontecer. O Custo dos Produtos Vendidos (CPV) é uma variável endógena ao modelo. Para atrelá-la à variação das Receitas Líquidas, será necessário achar, primeiramente, o Giro dos estoques (Ge) pela expressão:

$$
\text { - Ge}=C P V / E m
$$

O Capital de Giro (CDG) sofre influência das seguintes variáveis principais:• Autofinanciamento; Aumento de capital; Empréstimos de longo prazo; Investimentos em ativo permanente. Quando as três primeiras variáveis aumentam, o CDG aumenta. Quando os investimentos em ativo permanente diminuem, o CDG aumenta. São decisões estratégicas de longo prazo e que deverão ser tomadas pelo gestor em seu planejamento de Capital de Giro projetado para três exercícios futuros. Temos, entretanto, que:

- $\triangle C D G=$ financiamentos externos a longo prazo + autofinanciamento - investimentos em ativos permanentes 
Para o modelo em questão, o CDG é considerado uma variável endógena, pois é mantido o mesmo percentual de autofinanciamento, em relação às Receitas Líquidas (RL). Segundo Brasil e Brasil (2003, p.11), “[...] o autofinanciamento é a principal fonte de crescimento do CDG, ao ser incorporado ao patrimônio líquido da empresa". Portanto, quando RL variar, a diferença do autofinanciamento será incorporada ao CDG. A variável Caixa em excesso (Ce) é uma variável endógena e passa a ser dependente da variação da variável NCG, também uma variável endógena, e também da variação do valor do autofinanciamento, ambas dependentes da variação da variável de decisão RL. Segundo ROSS; WESTERFIELD; JAFFE (2002, p. 362) muitas empresas simplesmente baseiam suas decisões de estrutura de capital nas médias setoriais, pois as empresas existentes em qualquer setor são as sobreviventes, não se afastando das práticas usuais. Em relação ao imposto de renda e contribuição social (IRCS), o valor inicial da variável será o valor retirado dos demonstrativos contábeis. Caso o lucro bruto operacional (LBO) sofra variação após a otimização, a diferença entre o valor original do LBO, em relação ao novo valor que o modelo impuser, sofrerá taxação do IRCS e será incorporado ao novo valor do IRCS. Com estas últimas colocações, todas as variáveis relevantes foram classificadas e identificadas, a formulação da função objetivo definida e as restrições e considerações formuladas. 


\section{3. - METODOLOGIA.}

Segundo, Gaskell (2000, p.68) a finalidade da pesquisa qualitativa não é contar opiniões ou pessoas, mas ao contrário, explorar o espectro de opiniões, as diferentes representações sobre o assunto em questão, por meio de entrevistas individuais e grupo focal.

A pesquisa realiza uma análise descritiva do modelo Fleuriet de avaliação da posição financeira de negócios, incorporando seus principais aprimoramentos surgidos nesses últimos anos.

Aplica-se a metodologia desenvolvida a uma amostra de 26 empresas que compõem o grupo Demais Empresas representando diversos setores.

Estas empresas nos anos pesquisados apresentaram 68\% dos investimentos foram financiados com capital próprio.

Após a coleta de informações necessárias para desenvolver o estudo foram criados bancos de dados, em planilha eletrônica com as informações financeiras das empresas, de forma a facilitar a aplicação das ferramentas da planilha e do modelo. As informações coletadas referem-se aos anos de 2005, 2006 e 2007.

Para a realização do estudo, as demonstrações contábeis originais das empresas foram extraídas da página eletrônica do Departamento de Coordenação e Controle das Empresas Estatais (DEST). Para a composição das análises foram pesquisadas as seguintes informações:

$>$ Balanço Patrimonial;

Demonstração do Resultado do Exercício;

$>$ Notas Explicativas e

$>$ Relatórios da Administração.

A presenta-se a estratégia de pesquisa adotada para a construção deste estudo, com destaque para a Análise Dinâmica com a abordagem do modelo Fleuriet. A lógica da estratégia de pesquisa, ela pode ser percebida através de um roteiro sintético com vista a demonstrar como a estratégia de pesquisa foi construída, pelos seguintes etapas: 
o problema de pesquisa como inspiração para o estudo, fica externo ao esquema metodológico,ou seja, o problema de pesquisa é representado não como parte da metodologia, mas como"ponto gatilho" ou ponto de partida impulsionando e motivando a pesquisa;

a revisão da literatura sobre o tema de Análise das Demonstrações Contábeis, por meio de levantamento bibliográfico teórico-conceitual;

$>$ levantamento das Demonstrações Contábeis e outras informações relevantes sobre as empresas estudadas e

a aplicação das técnicas de Análise das Demonstrações Contábeis e a interpretação dos resultados obtidos, abordando as metodologia tradicional adotada pelo DEST e o modelo Fleuriet (dinâmico) e após o cumprimento de todas as fases descritas neste roteiro.

\section{1- Tipo de pesquisa.}

A lógica da estratégia de pesquisa foi construída, pelos seguintes etapas:

o problema de pesquisa como inspiração para o estudo, fica externo ao esquema metodológico,ou seja, o problema de pesquisa é representado não como parte da metodologia, mas como"ponto gatilho" ou ponto de partida impulsionando e motivando a pesquisa;

$>$ a revisão da literatura sobre o tema de Análise das Demonstrações Contábeis, com aquisição do conhecimento, por meio de levantamento bibliográfico teórico-conceitual;

> levantamento das Demonstrações Contábeis e outras informações relevantes sobre as empresas estudadas e

$>$ aplicação das técnicas de Análise das Demonstrações Contábeis e a interpretação dos resultados obtidos, abordando as metodologias 
tradicionais.

A pesquisa foi quantitativa e qualitativa. Quantitativa, pois prevê o cálculo de variáveis preestabelecidas no modelo Fleuriet (FLEURIET; KEHDY; BLANC, 2003), como:

$>$ capital de giro;

$>$ necessidade de capital de giro;

$>$ saldo de tesouraria e

$>$ autofinanciamento.

Além da mensuração dessas variáveis, foi verificado o interrelacionamento entre elas no intuito de identificar as estratégias de financiamento utilizadas pelas empresas federais.

Já a abordagem qualitativa foi utilizada por avaliar os resultados individuais apresentados por cada empresa deste estudo, pois, cada entidade apresenta natureza das suas atividades e os resultados das variáveis de forma peculiar. Esse fato faz com que cada organização seja analisada sob a dinâmica interna dos seus processos e sob as atividades desenvolvidas por elas. Diante desses fatores, será utilizada nesta pesquisa a triangulação; a análise qualitativa dos processos e das atividades desenvolvidas pelas empresas deste estudo complementa a abordagem quantitativa, que, por sua vez, é caracterizada neste trabalho por meio do cálculo das variáveis do modelo Fleuriet (FLEURIET; KEHDY; BLANC, 2003).

Já a abordagem qualitativa foi utilizada para avaliar os resultados individuais apresentados por cada empresa deste estudo, pois, cada entidade apresenta natureza das suas atividades e os resultados das variáveis de forma peculiar. Esse fato faz com que cada organização seja analisada sob a dinâmica interna dos seus processos e sob as atividades desenvolvidas por elas. Nesse tipo de pesquisa, os fatos são observados, registrados, analisados, classificados e interpretados sem que o pesquisador interfira neles (ANDRADE, 2003, p.124). 


\section{2 - Procedimentos de coleta dos dados.}

A pesquisa é classificada como bibliográfica, documental e estudo de casos múltiplos e o desenvolvimento do trabalho ocorreu em duas etapas:

a primeira etapa, essencialmente teórica, com revisão bibliográfica sobre o tema central e suas derivações é considerada pesquisa bibliográfica e

$>$ a segunda etapa do estudo será constituída por análise documental. Foram utilizados os demonstrativos financeiros das empresas públicas federais de capital fechado. Através da descrição, análise e interpretação dos citados documentos, no período de 2005 a 2007, além da leitura de contratos, normas, e legislação específica. Assim, a técnica utilizada foi a pesquisa documental, além do método de estudo de caso.

Conforme SANTOS (1999), na pesquisa documental são fontes aqueles que não receberam organização, tratamento analítico e publicação. São fontes documentais as tabelas estatísticas, relatórios de empresas, documentos informativos arquivados em órgãos públicos, associações, obras originais de qualquer natureza, correspondência comercial dentre outros.

Já o estudo de caso, segundo o mesmo autor, ocorre quando se seleciona um objeto de pesquisa restrito, com o objetivo de aprofundar-lhe os aspectos característicos, cujo objeto pode ser qualquer fato/fenômeno individual, ou um de seus aspectos. Utiliza-se o estudo de caso quando se trata de reconhecer num caso, um padrão científico já delineado, no qual possa ser enquadrado. Por lidar com fatos e fenômenos normalmente isolados, o estudo de caso exige do pesquisador grande equilíbrio intelectual e capacidade de observação, além de parcimônia quanto a generalização de resultados.

Então os elementos da realidade a ser analisada são as empresas públicas federais de capital fechado e a amostra é de natureza não probabilística composta de vinte e seis instituições.

Os dados para a composição da base teórica foram obtidos, por meio de livros, artigos, teses, revistas, jornais, relatórios do DEST e outros suplementos bibliográficos. Para 
composição do estudo de casos múltiplos será utilizado as demonstrações financeiras e relatórios da administração publicadas por estas empresas.

\section{3- Análise dos dados.}

O tratamento dos dados contempla: os dados que compõem a base teórica (livros, artigos, revistas, jornais e outros) justificarão e farão a comparação do objetivo do trabalho, pois estes dados formarão a segurança para a conclusão do mesmo. Os dados que compõem a parte empírica do estudo (demonstrações financeiras, relatórios,, tabelas estatísticas, e outros) constituirão a base para a análise e comparação dos resultados a serem encontrados, bem como o objetivo principal da conclusão. 


\section{4. - APRESENTAÇÃO DOS RESULTADOS}

Os Quadro apresentados a seguir apresenta os Balanços reorganizados para a análise dinâmica do capital de giro das empresas.

De posse dos dados financeiros montou-se a quadro de valor conforme o estabelecido no escopo do trabalho. O primeiro passo foi classificar as contas do balanço patrimonial de acordo com o Modelo Fleuriet. Com isto, obtiveram-se os resultados de NCG, CDG e ST, representados nos gráficos.

Foram calculados as seguintes variáveis:

Necessidade de Capital de Giro (NCG) = ATIVO CÍCLICO - PASSIVO CÍCLICO;

$>$ Saldo de Tesouraria $=$ Efeito Tesoura $=$ ATIVO ERRÁTICO - PASSIVO ERRÁTICO.

Outras observações importantes:

a RFFSA e a CEASA/AM foram excluídas do grupo de análise, pois estão EM LIQUIDAÇÃO;

$>$ devido a criação em 2007, não existem demonstrativos de 2005 e 2006 para EBC - Empresa Brasil Comunicação e

> não existe DRE de 2007 para a EMPRESA BRASILEIRA DE HEMODERIVADOS E BIOTECNOLOGIA (HEMOBRAS)

\section{1 - Balanços na formatação preconizada pelo Modelo Fleuriet.}

Os balanços foram adequados ao modelo para a análise dinâmica do capital de giro das 
empresas nos anos de 2005,2006 e 2007, conforme apresentação a seguir.

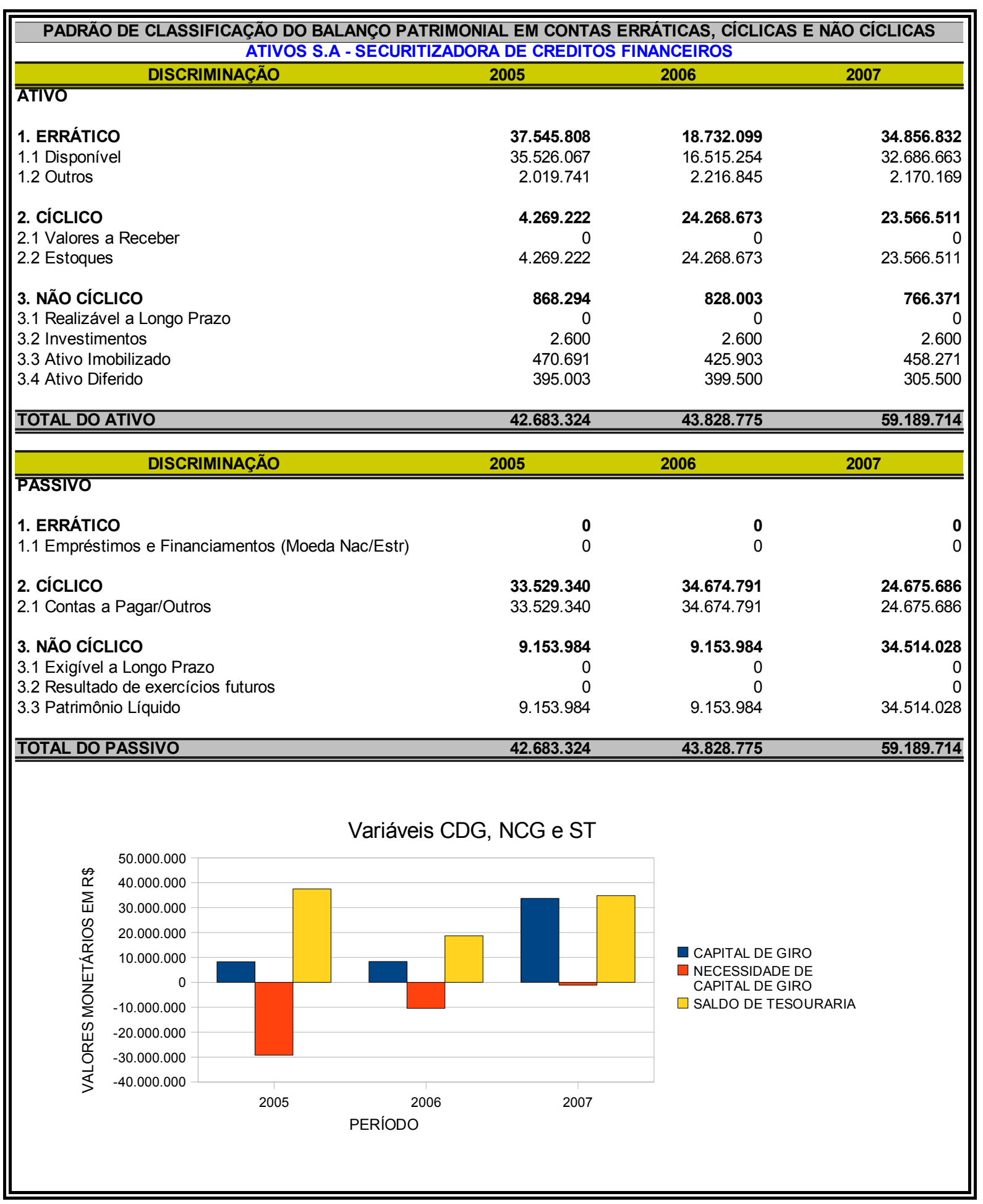

Gráfico 1. Ativos S.A

Fonte: adaptado do DEST( 2005, 2006 e 2007). 


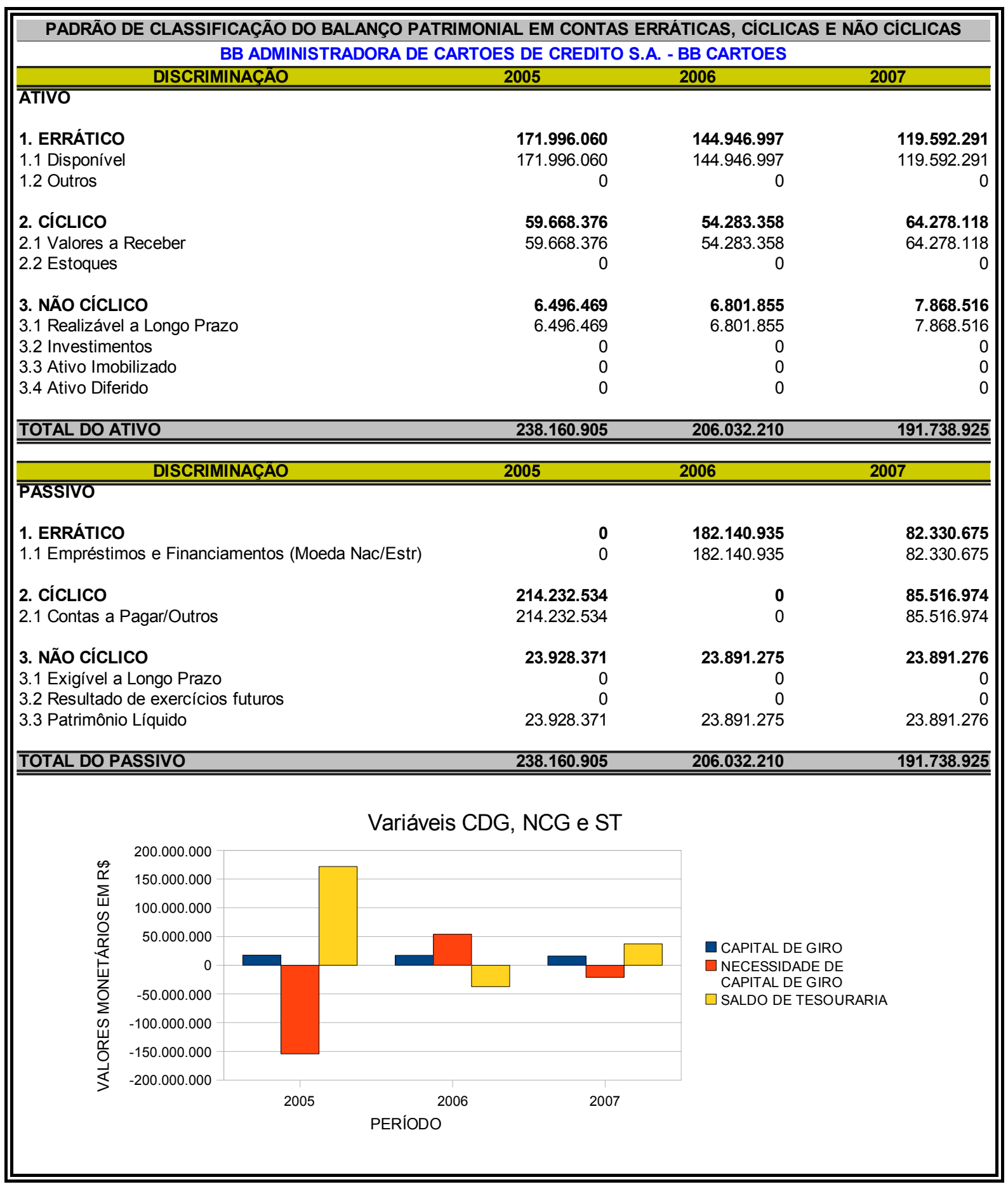

Gráfico 2. BB Cartões

Fonte: adaptado do DEST( 2005, 2006 e 2007). 


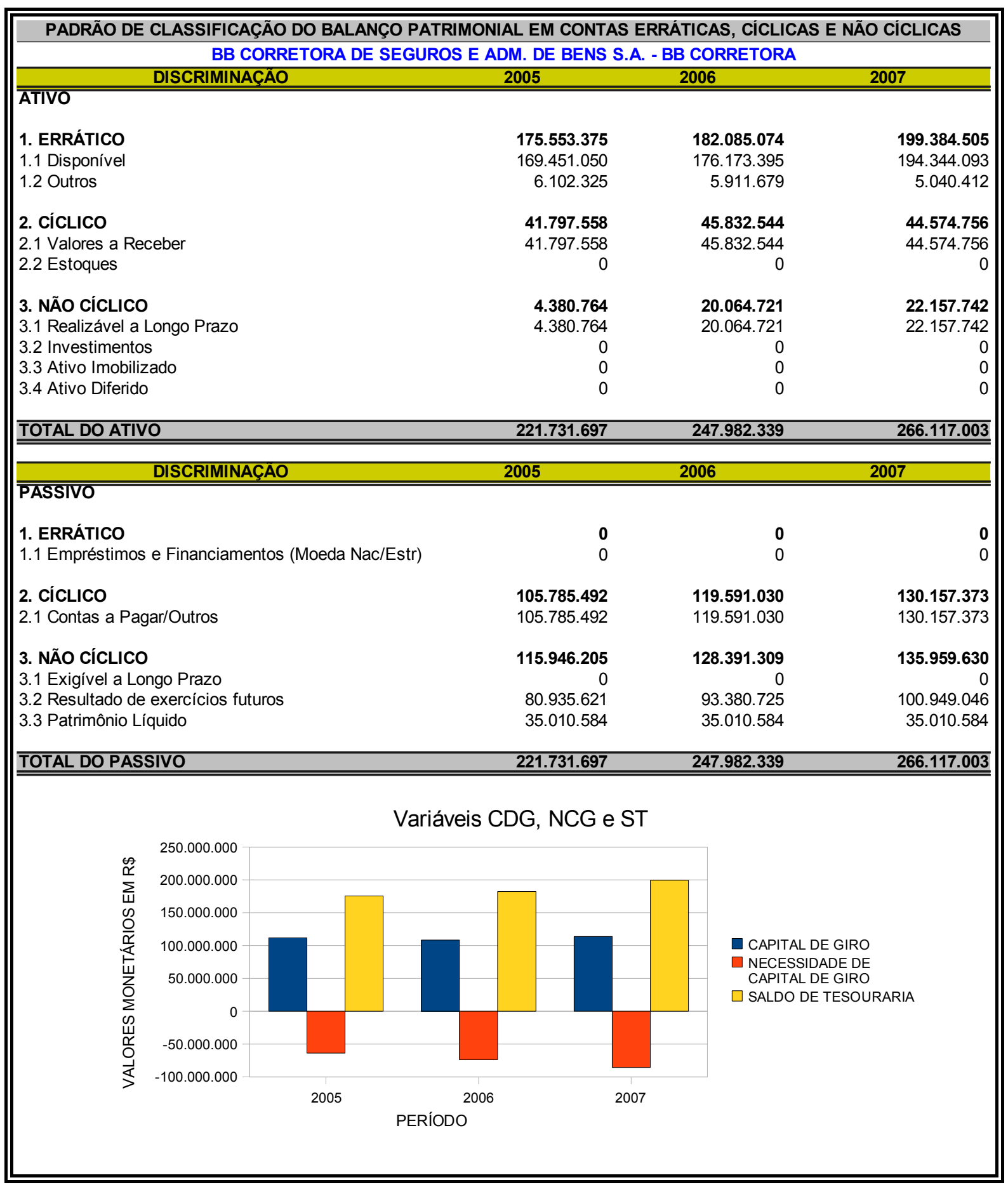

Gráfico 3. BB Corretora

Fonte: adaptado do DEST( 2005, 2006 e 2007). 


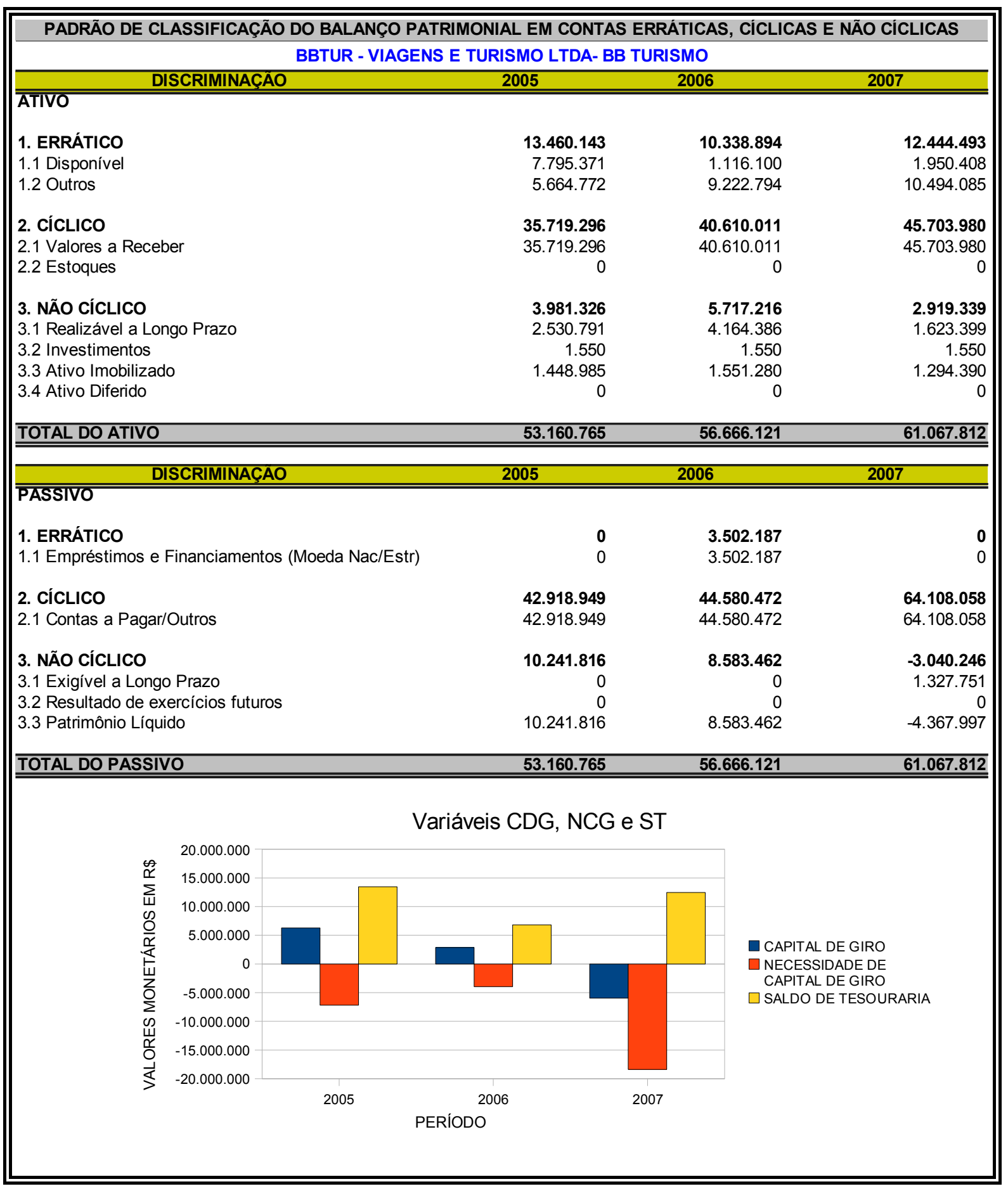

Gráfico 4. BB Turismo

Fonte: adaptado do DEST( 2005, 2006 e 2007). 


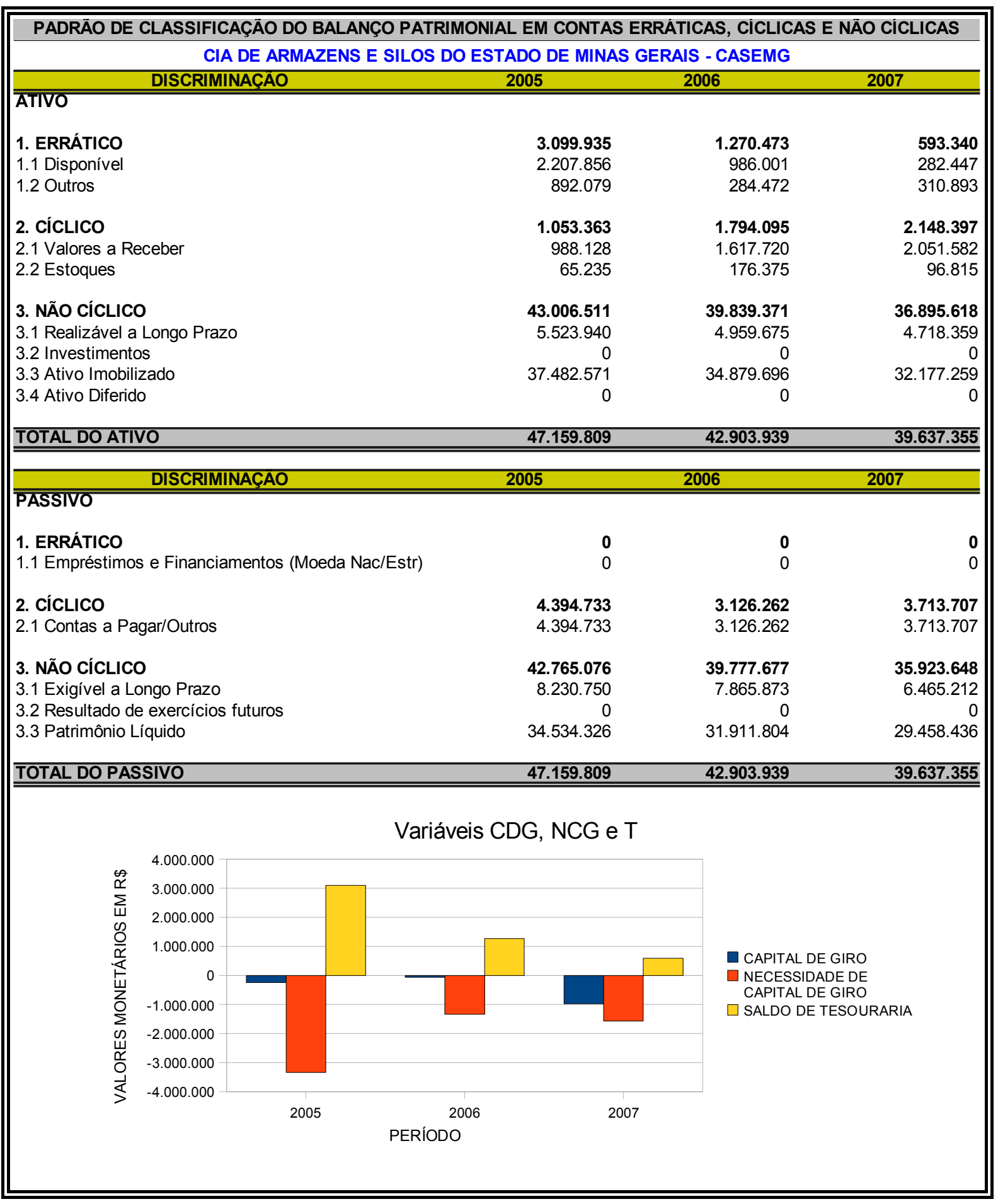

Gráfico 5. CAESMG

Fonte: adaptado do DEST( 2005, 2006 e 2007). 


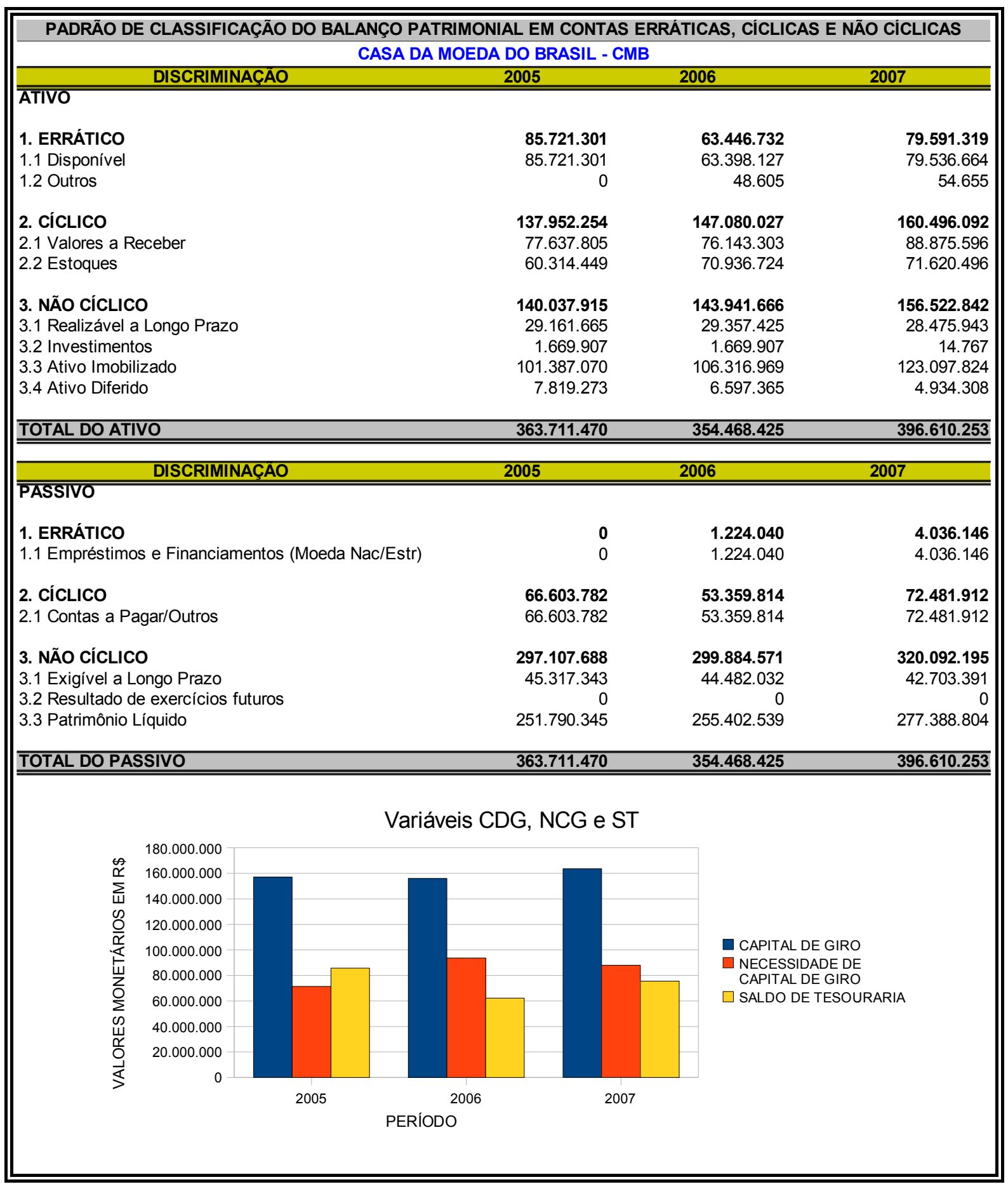

Gráfico 6. CMB

Fonte: adaptado do DEST( 2005, 2006 e 2007). 


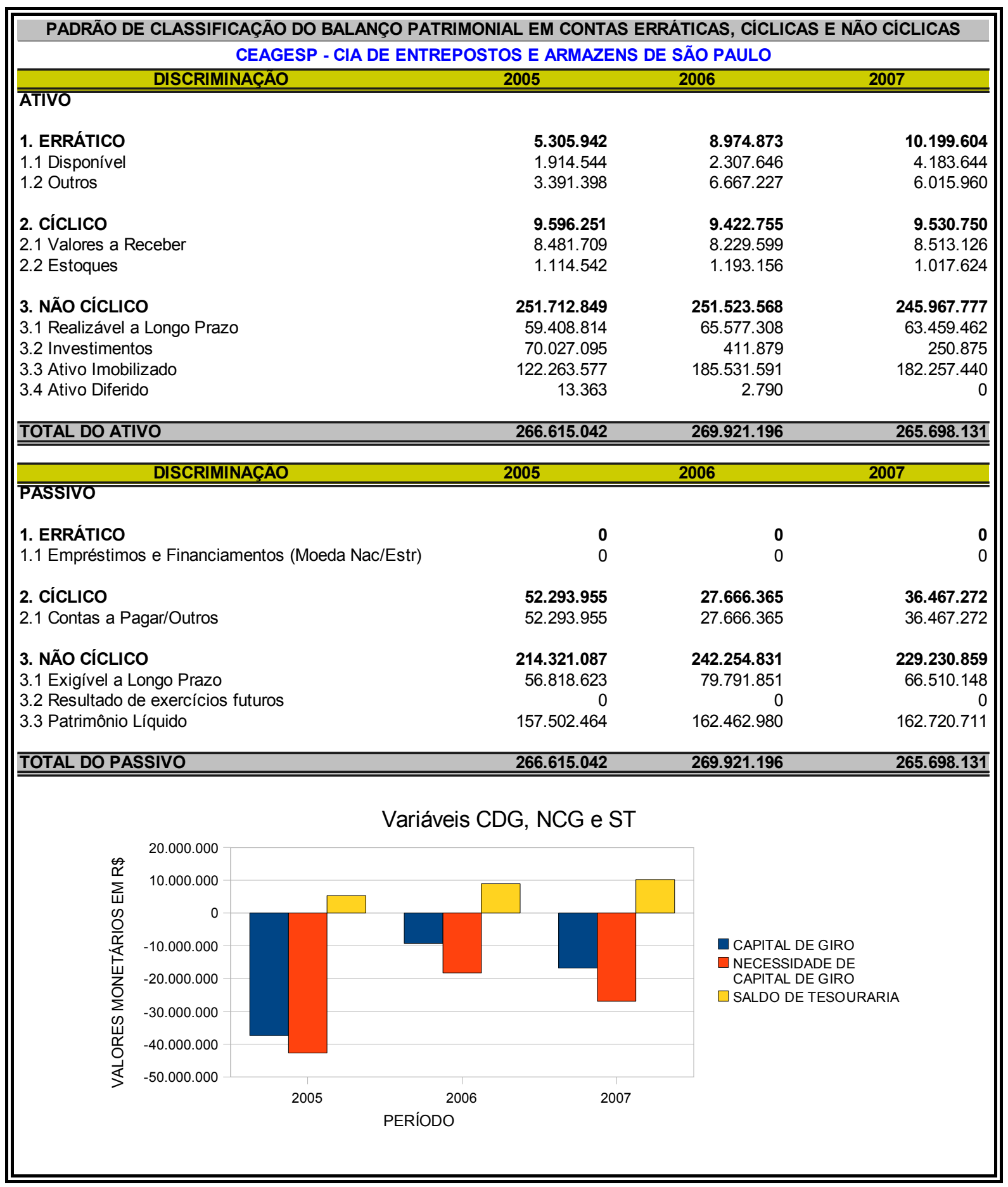

Gráfico 7. CEAGESP

Fonte: adaptado do DEST( 2005, 2006 e 2007). 


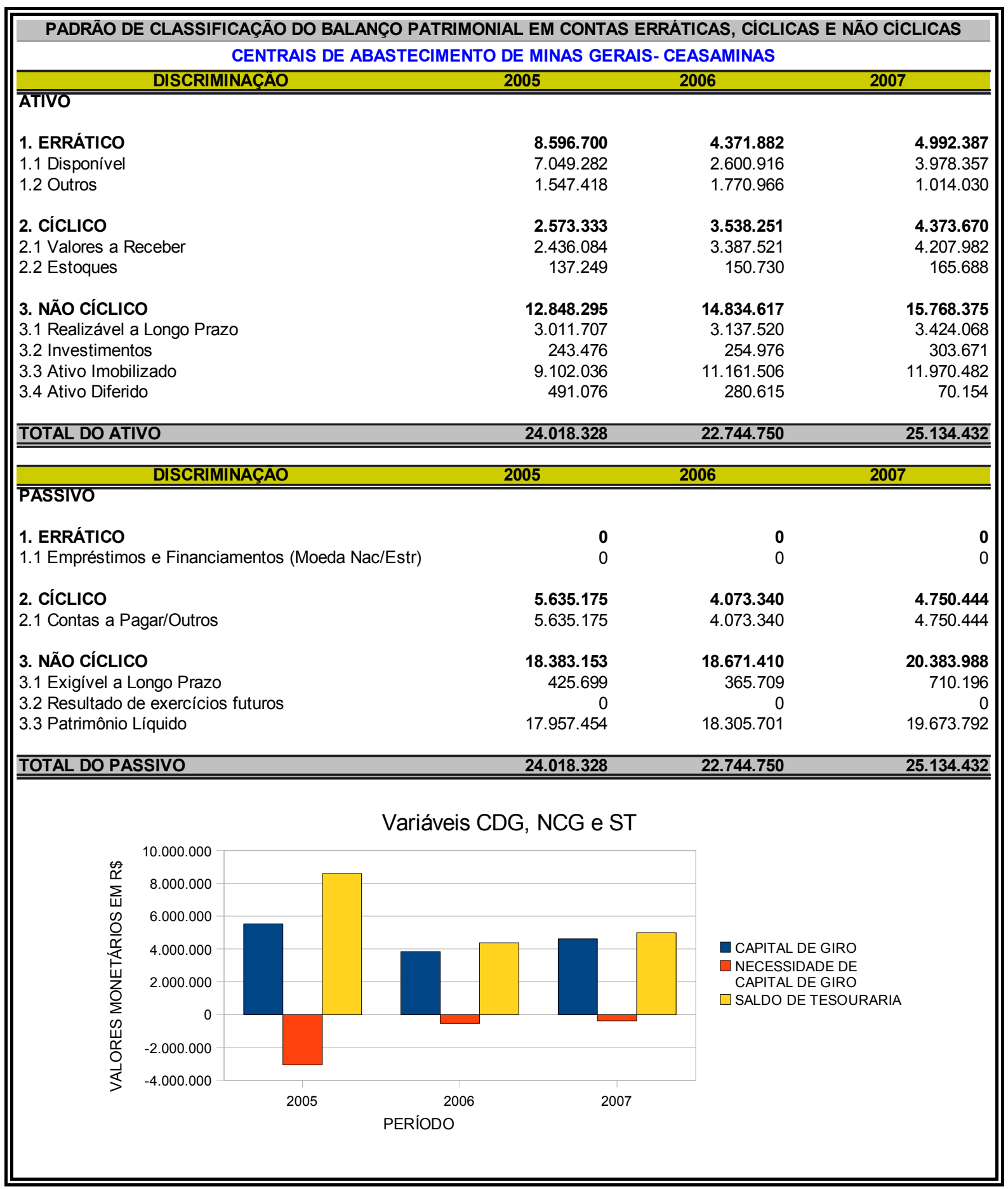

\section{Gráfico 8. CEASAMINAS}

Fonte: adaptado do DEST( 2005, 2006 e 2007). 


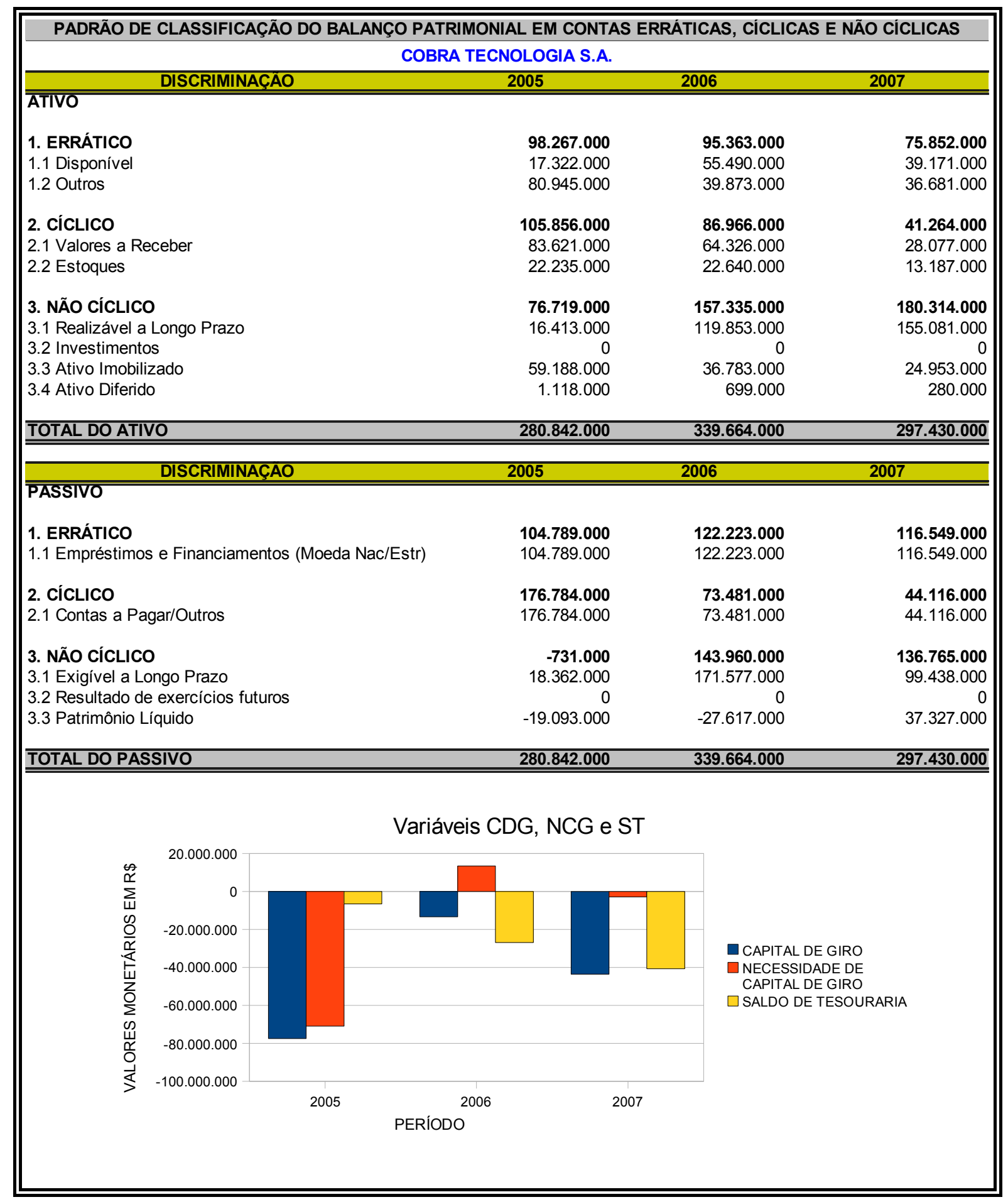

Gráfico 9. COBRA S.A

Fonte: adaptado do DEST( 2005, 2006 e 2007). 


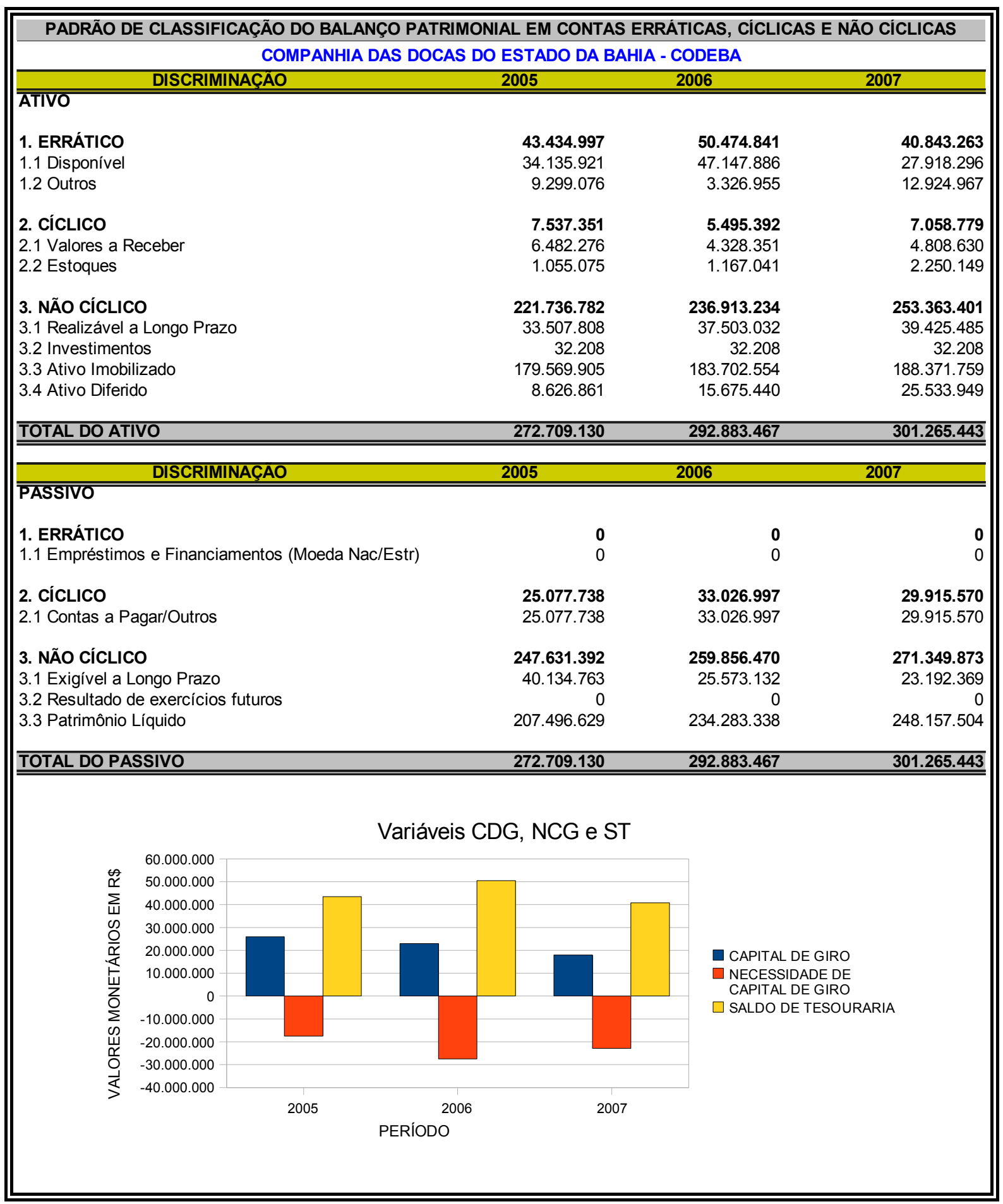

Gráfico 10. CODEBA

Fonte: adaptado do DEST( 2005, 2006 e 2007). 


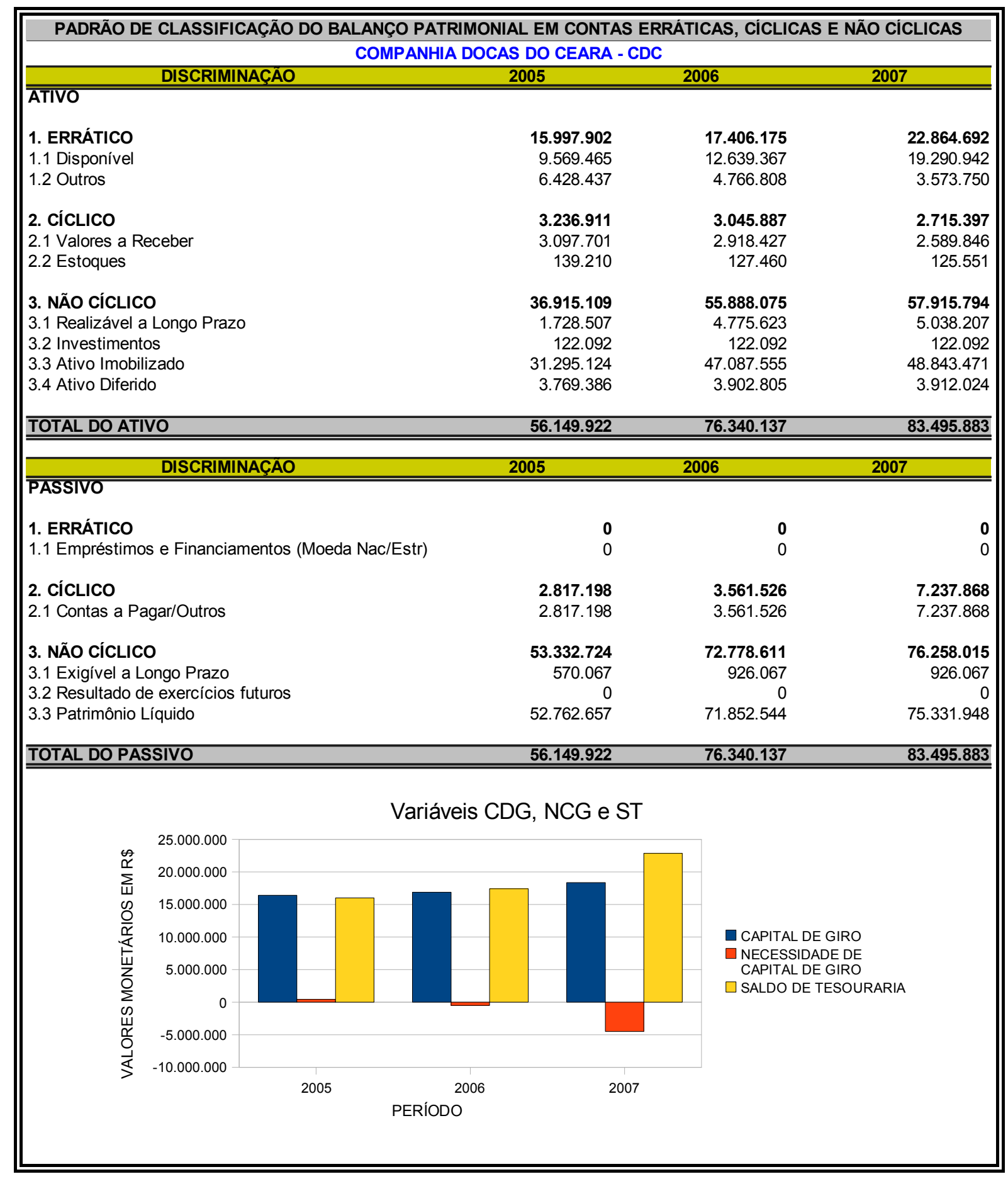

Gráfico 11. CDC

Fonte: adaptado do DEST( 2005, 2006 e 2007). 


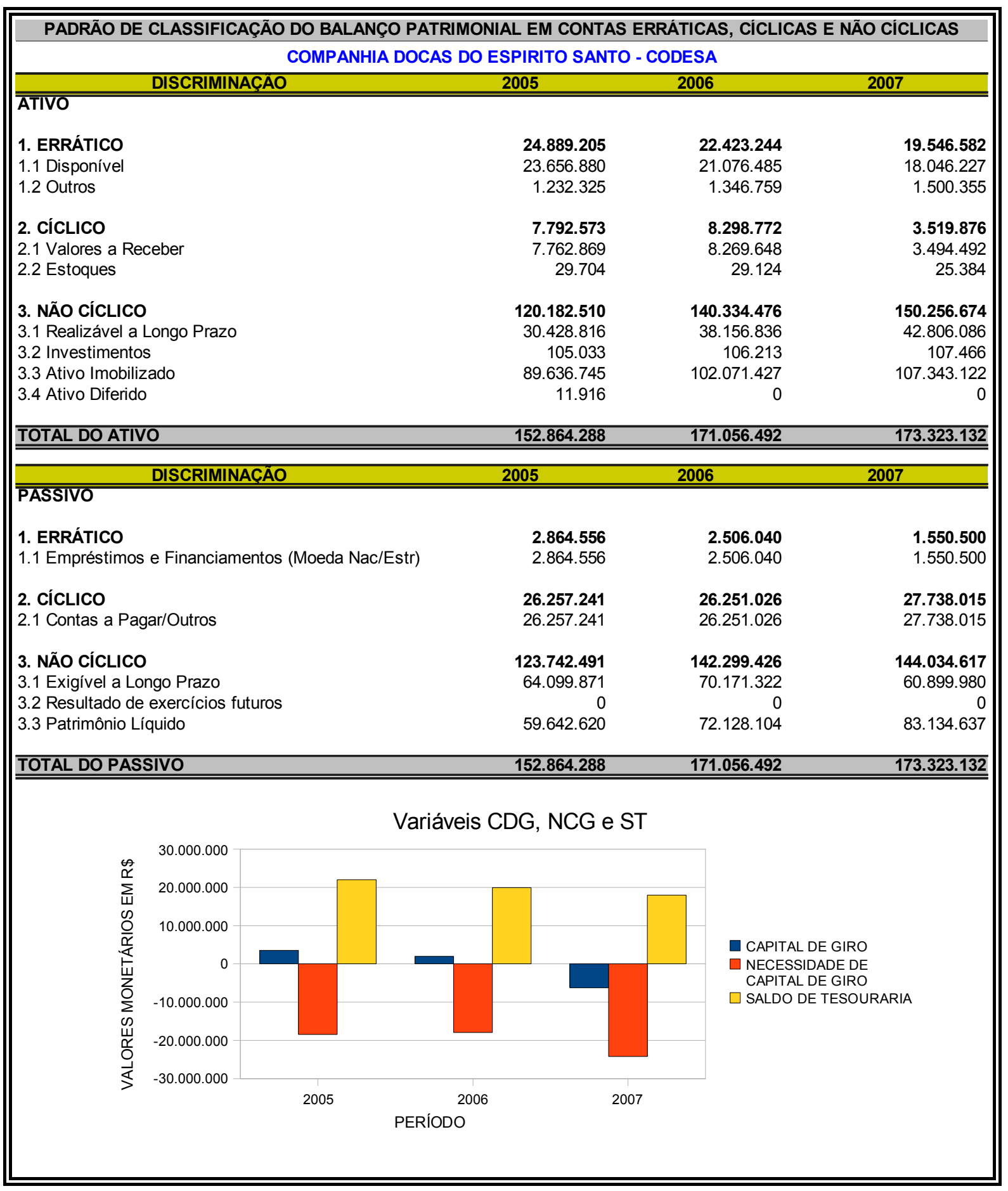

Gráfico 12. CODESA

Fonte: adaptado do DEST( 2005, 2006 e 2007). 


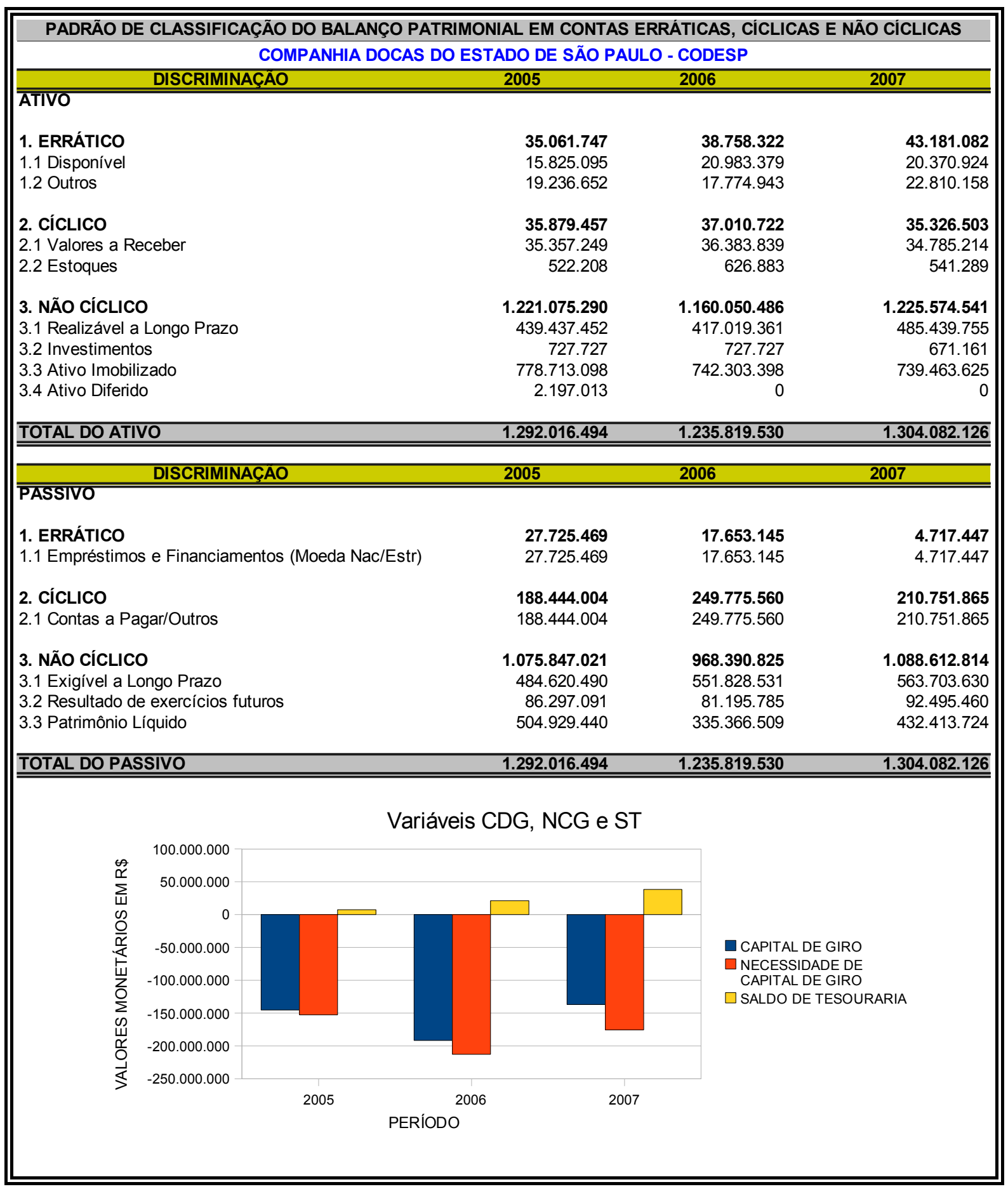

\section{Gráfico 13 CODESP}

Fonte: adaptado do DEST( 2005, 2006 e 2007). 


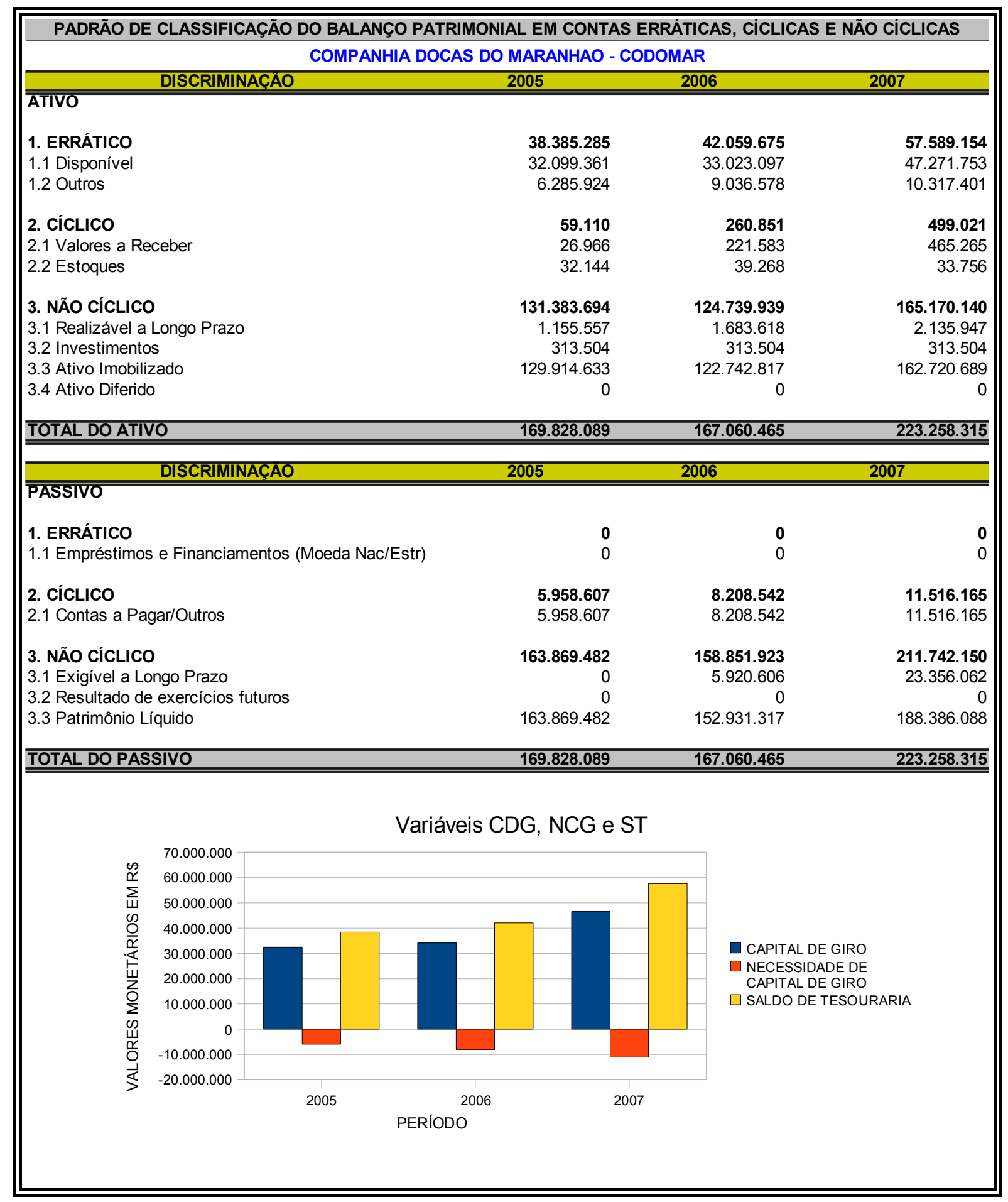

Gráfico 14. CODOMAR

Fonte: adaptado do DEST( 2005, 2006 e 2007). 


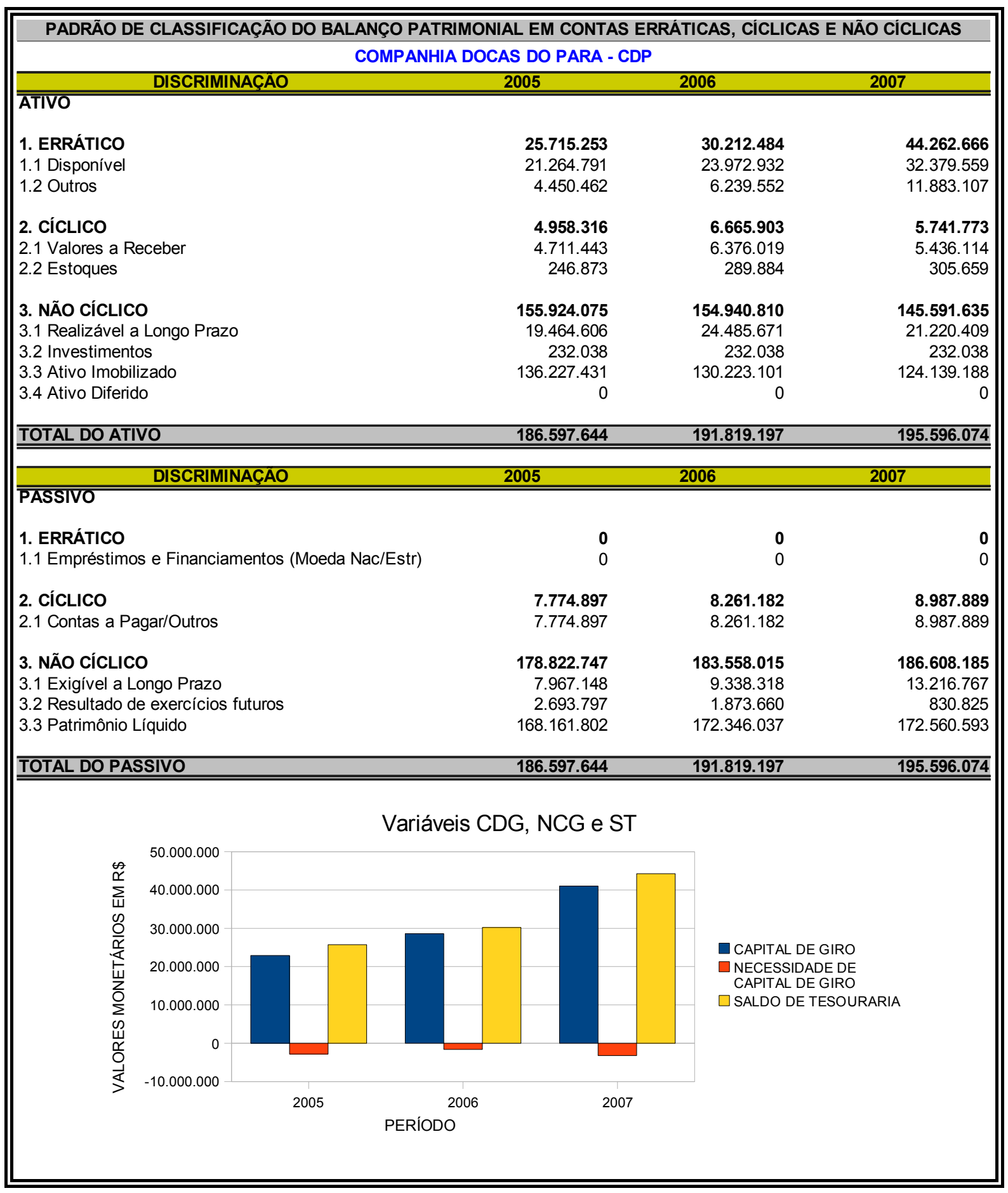

Gráfico 15. CDP

Fonte: adaptado do DEST( 2005, 2006 e 2007). 


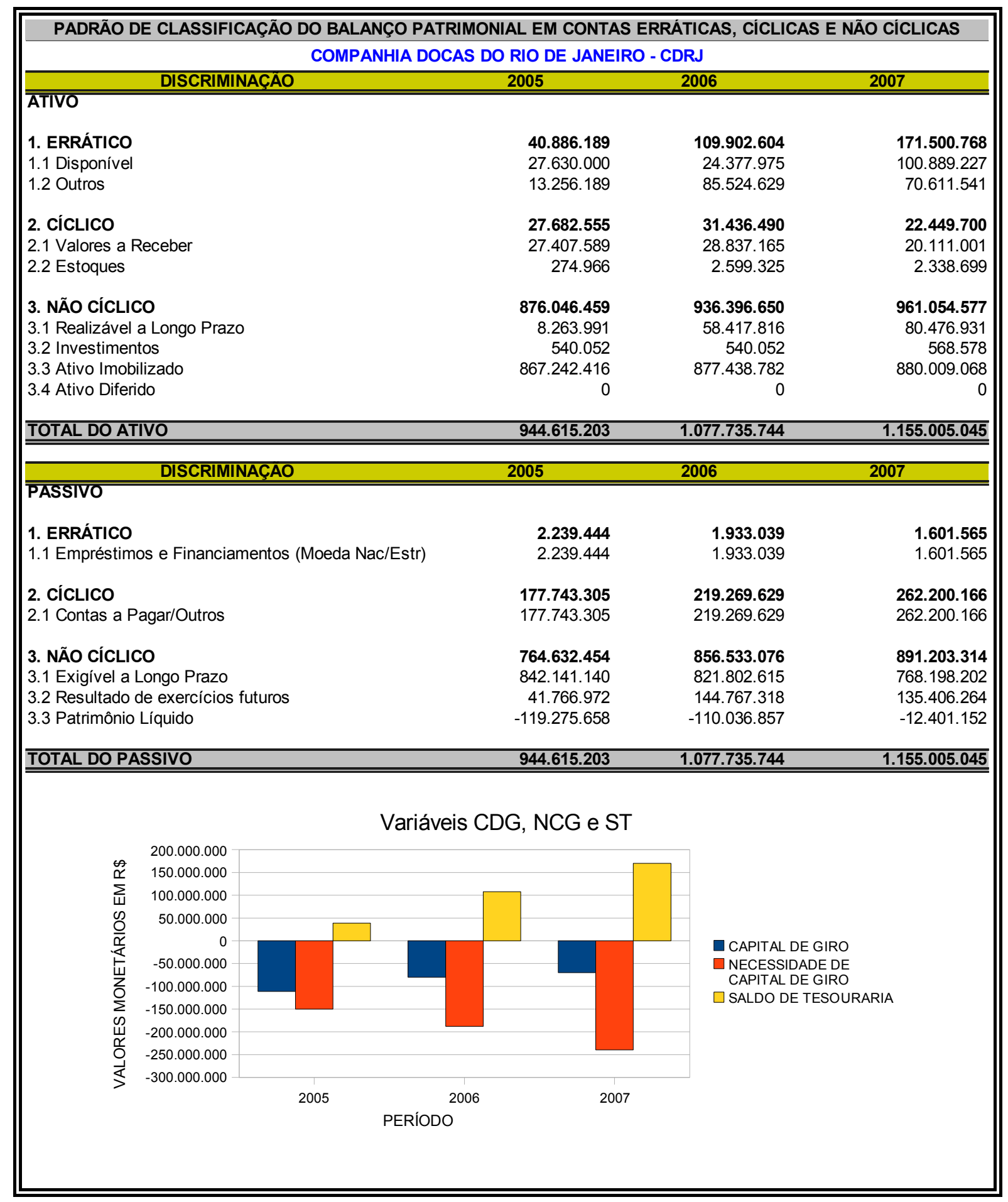

Gráfico 16. CDRJ

Fonte: adaptado do DEST( 2005, 2006 e 2007). 


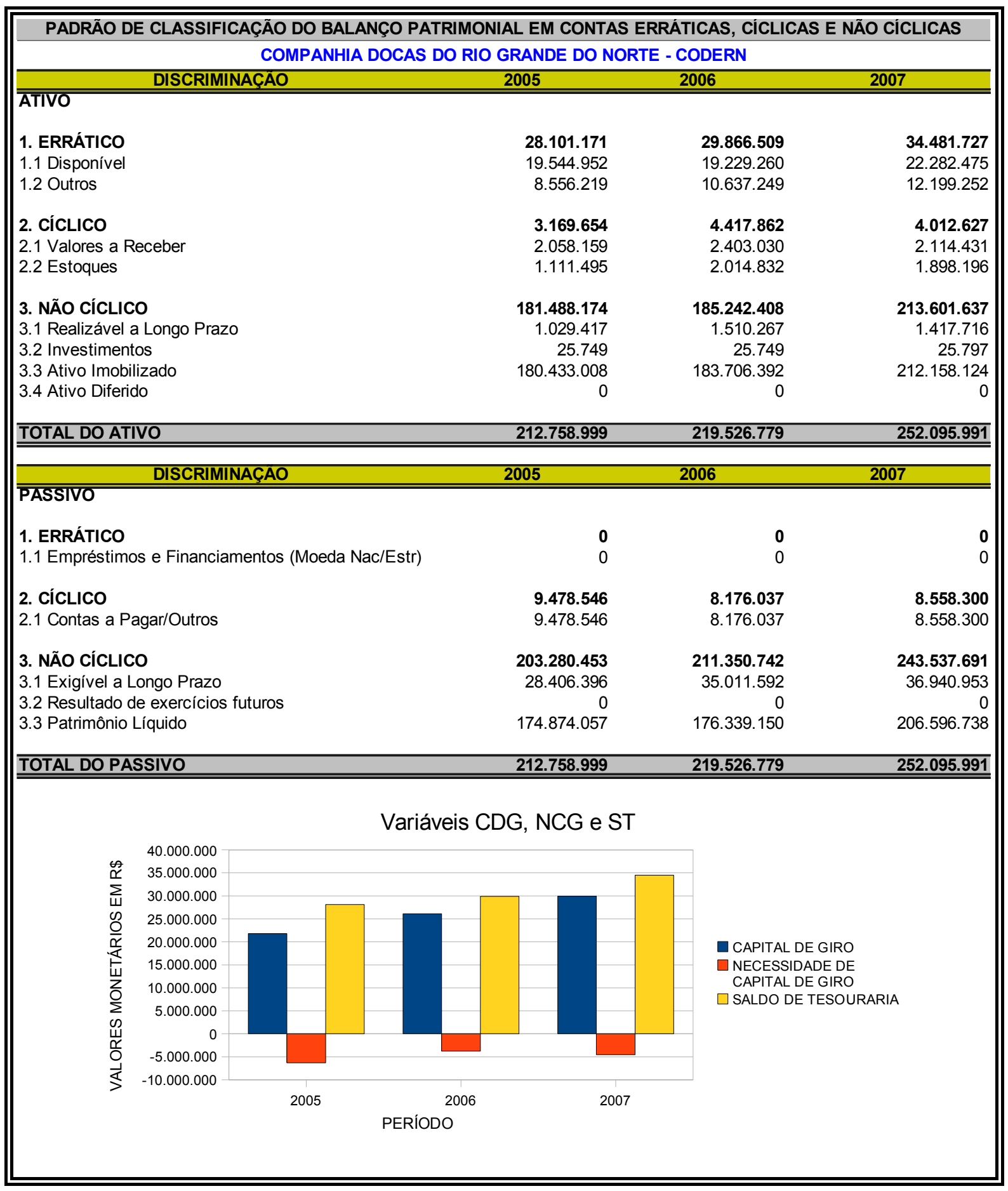

Gráfico 17. CODERN

Fonte: adaptado do DEST( 2005, 2006 e 2007). 


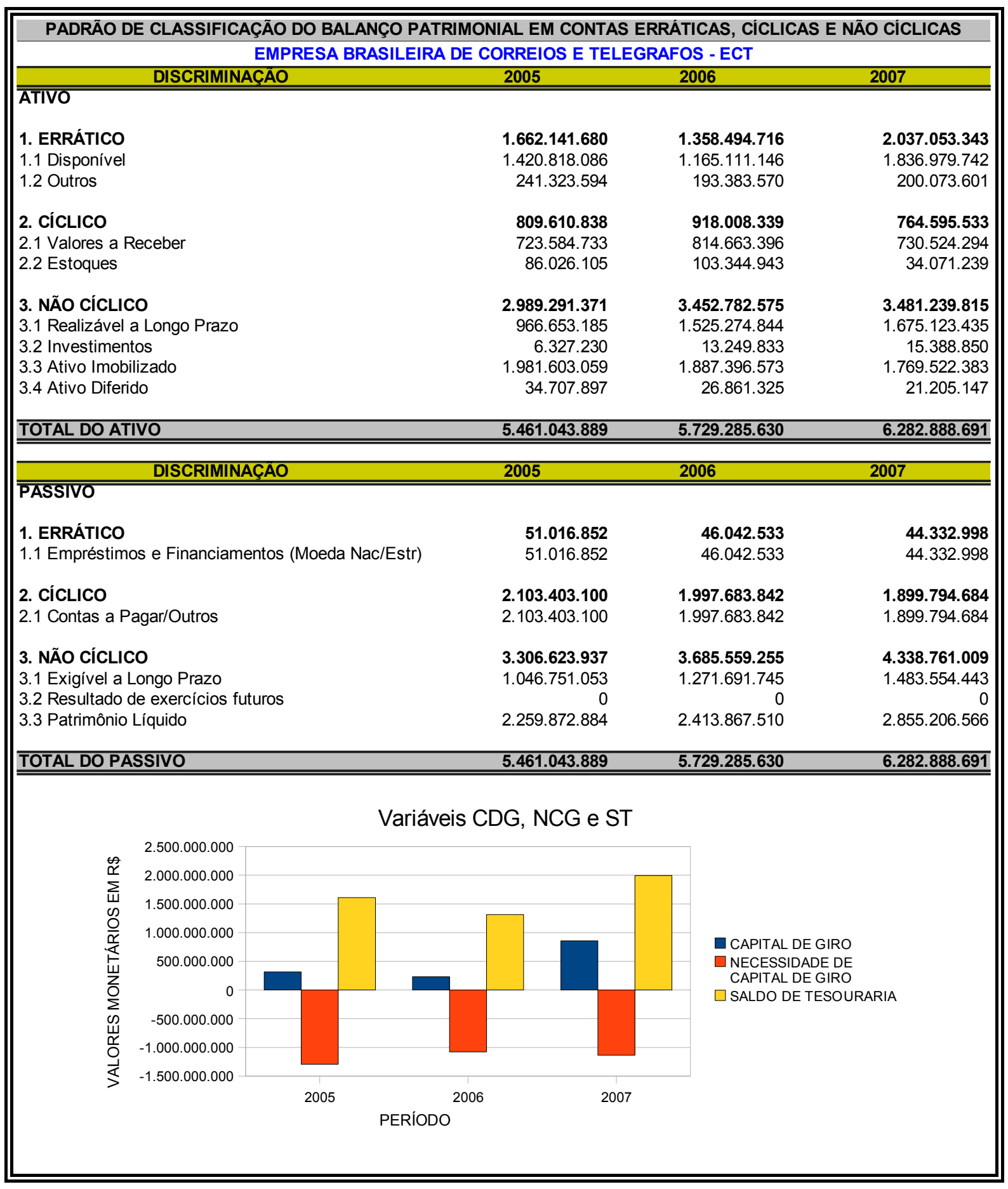

Gráfico 18. ECT

Fonte: adaptado do DEST( 2005, 2006 e 2007). 


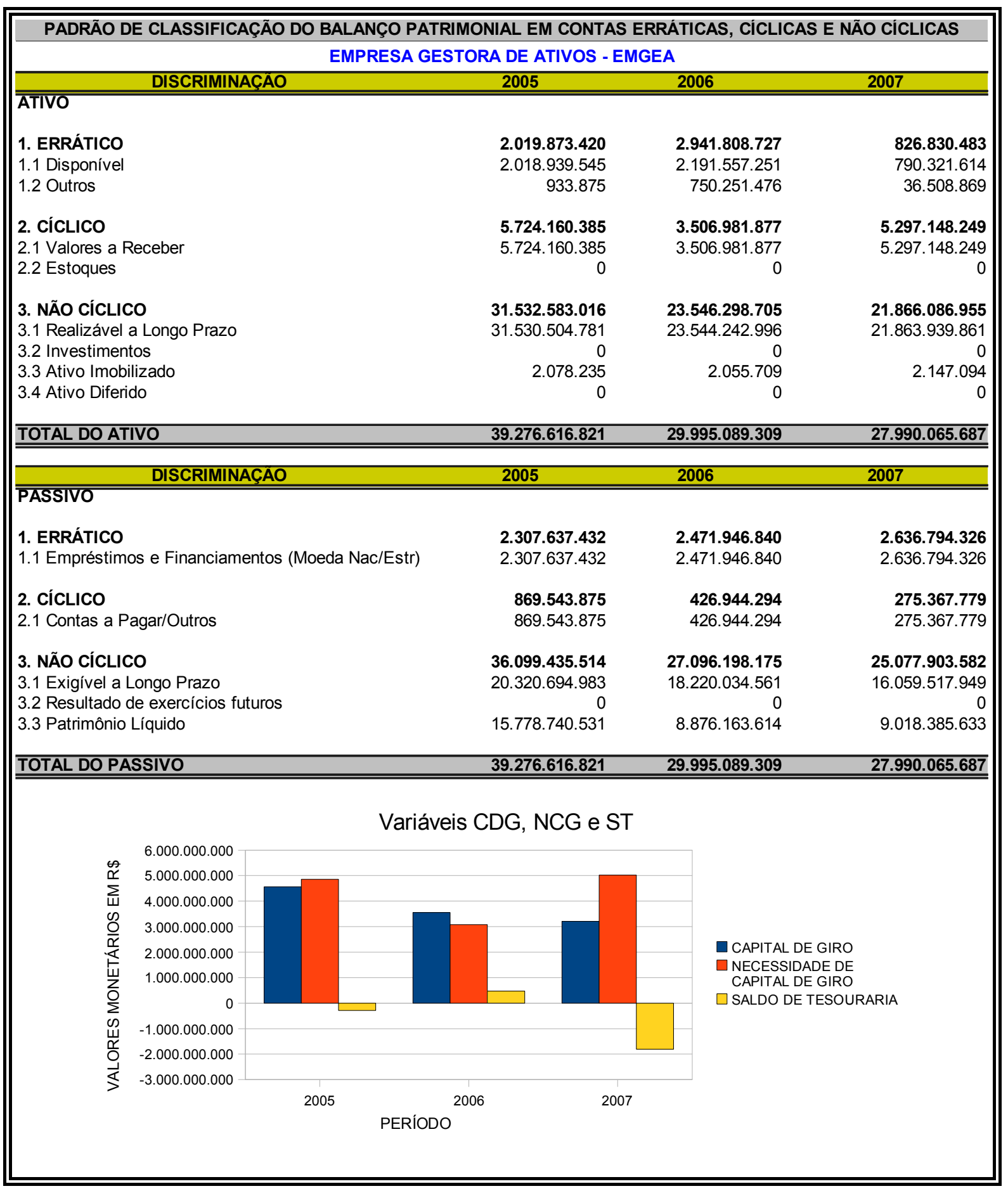

Gráfico 19. EMGEA

Fonte: adaptado do DEST( 2005, 2006 e 2007). 


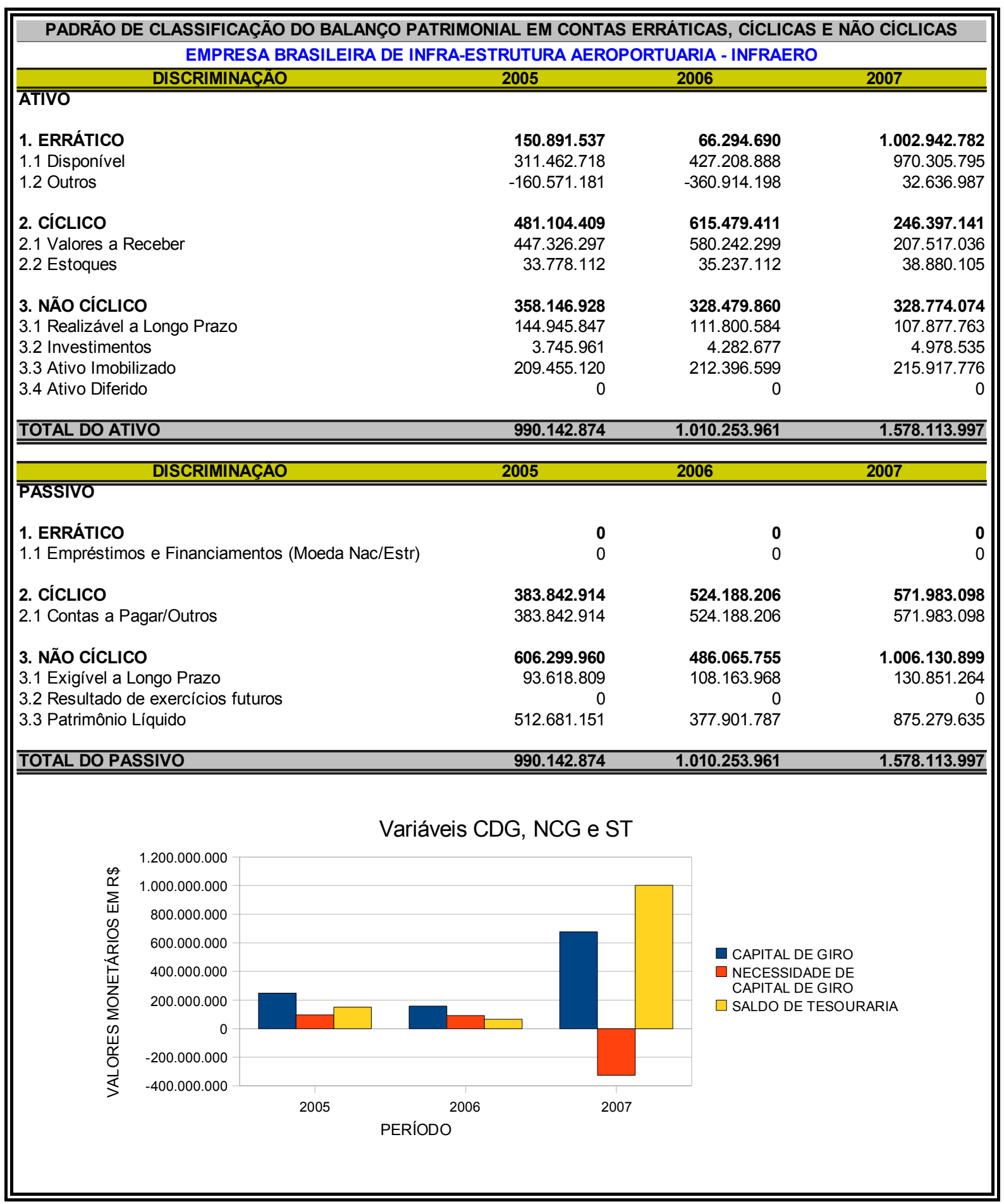

Gráfico 20. INFRAERO

Fonte: adaptado do DEST( 2005, 2006 e 2007). 


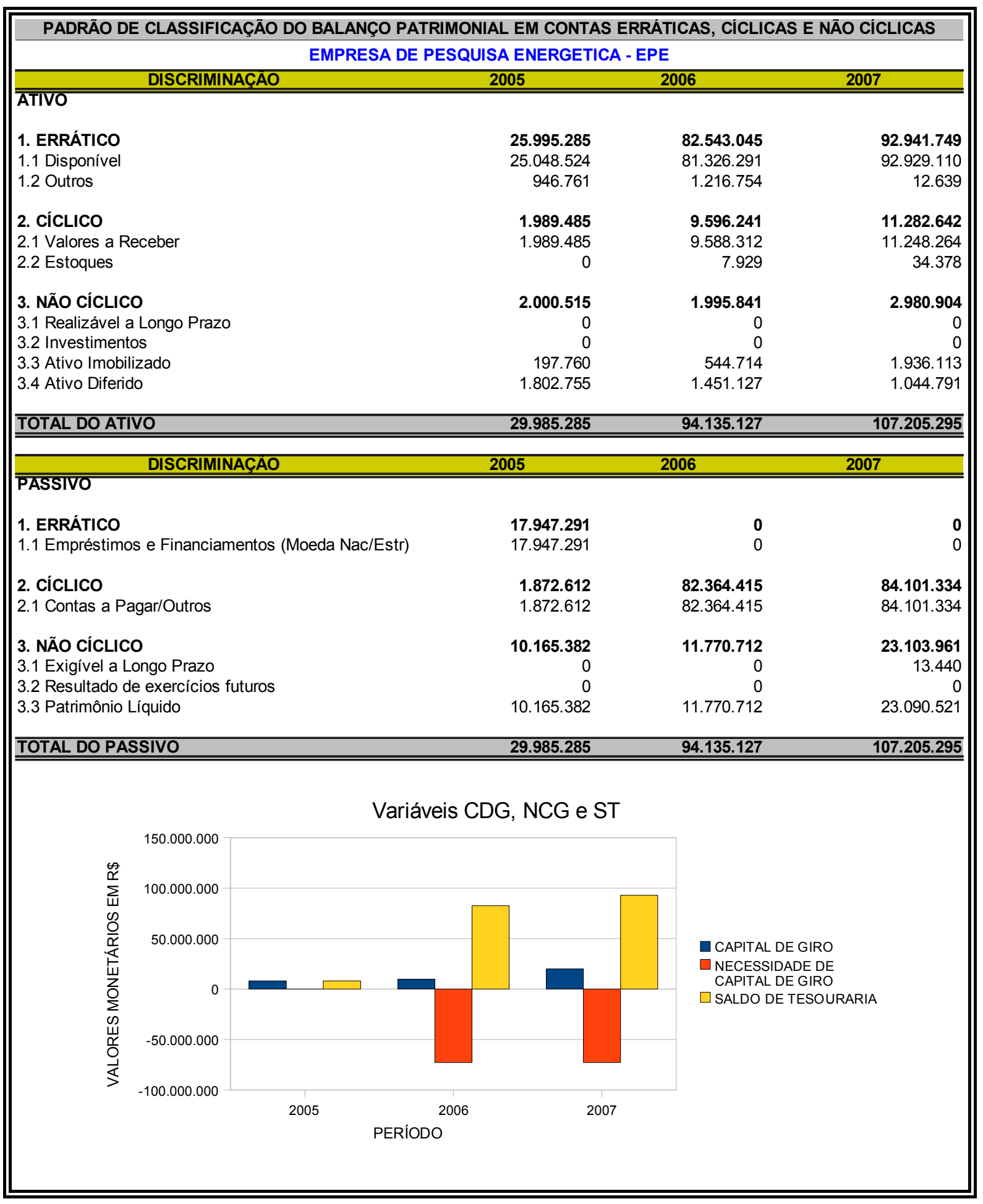

Gráfico 21. EPE

Fonte: adaptado do DEST( 2005, 2006 e 2007). 


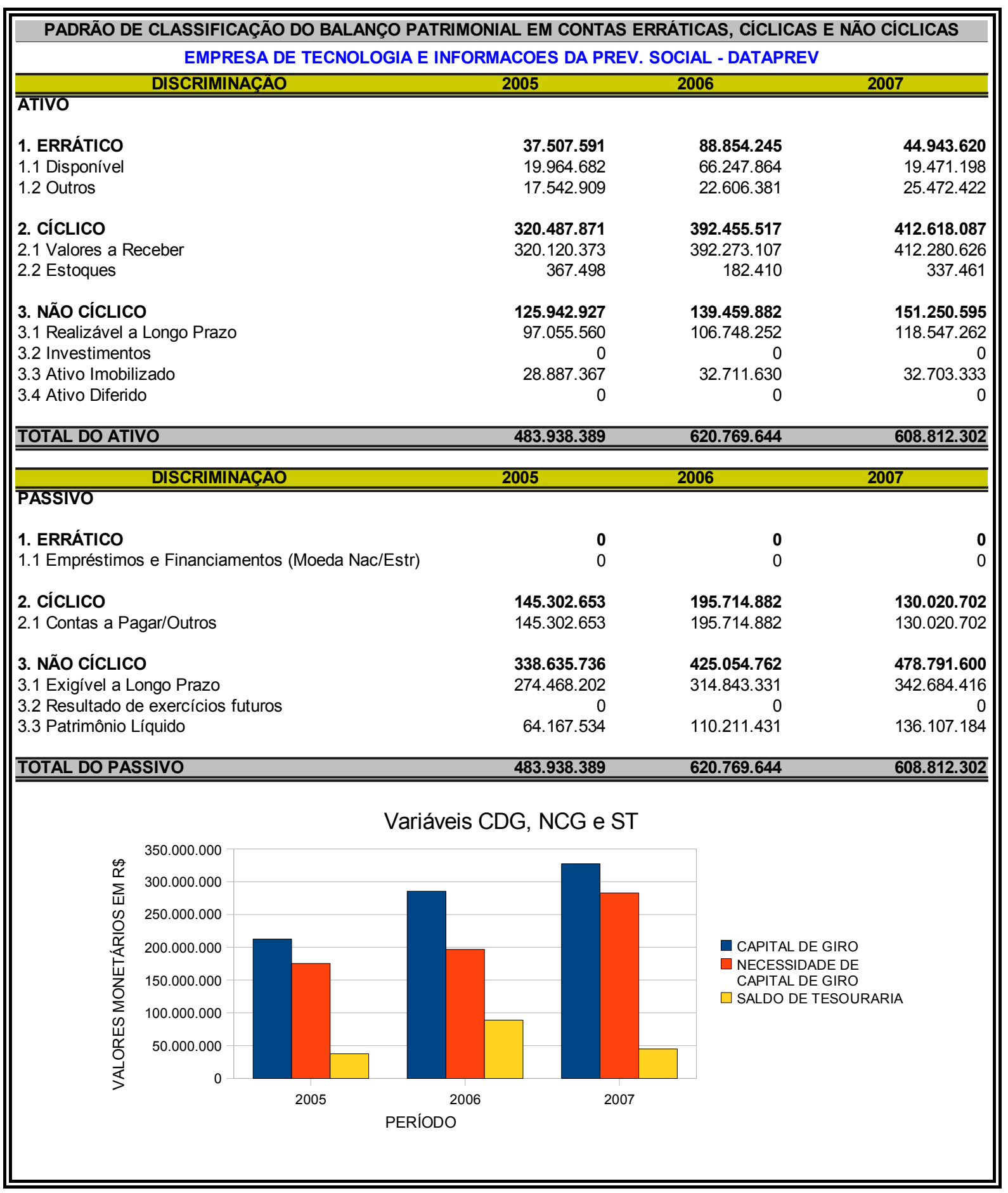

Gráfico 22. DATAPREV

Fonte: adaptado do DEST( 2005, 2006 e 2007). 


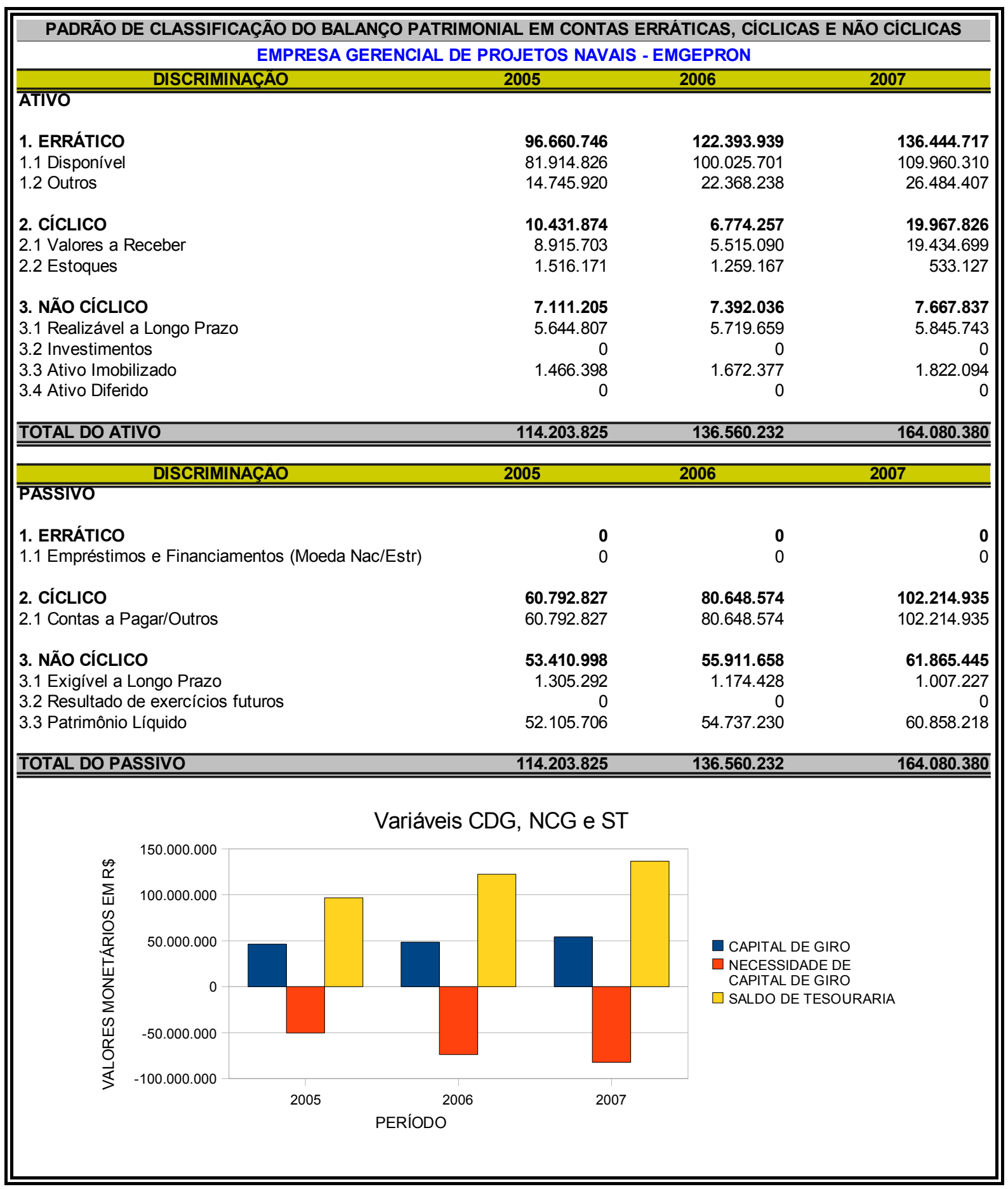

\section{Gráfico 23. EMGEPRON}

Fonte: adaptado do DEST( 2005, 2006 e 2007). 


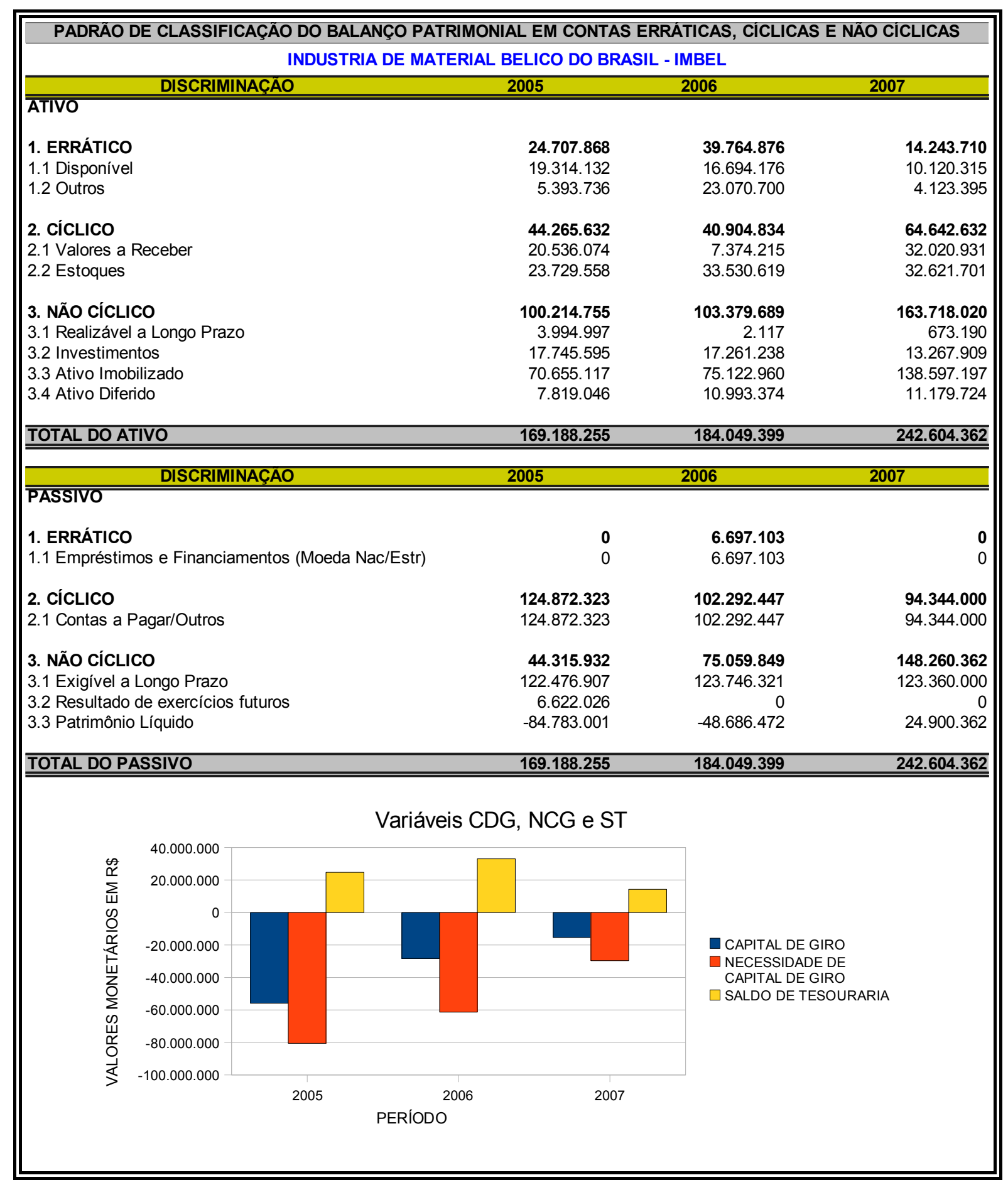

Gráfico 24. IMBEL

Fonte: adaptado do DEST( 2005, 2006 e 2007). 


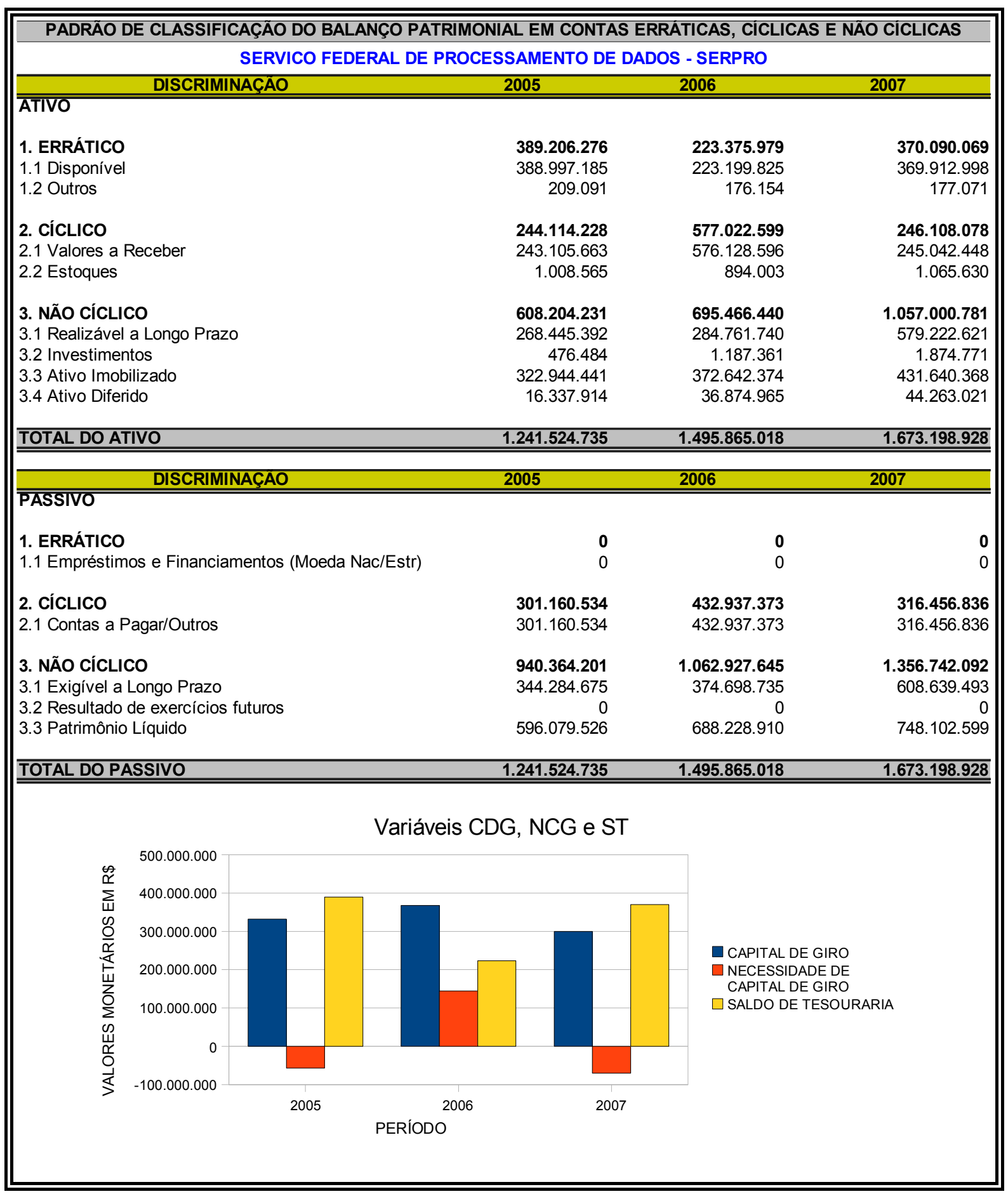

Gráfico 25. SERPRO

Fonte: adaptado do DEST( 2005, 2006 e 2007). 


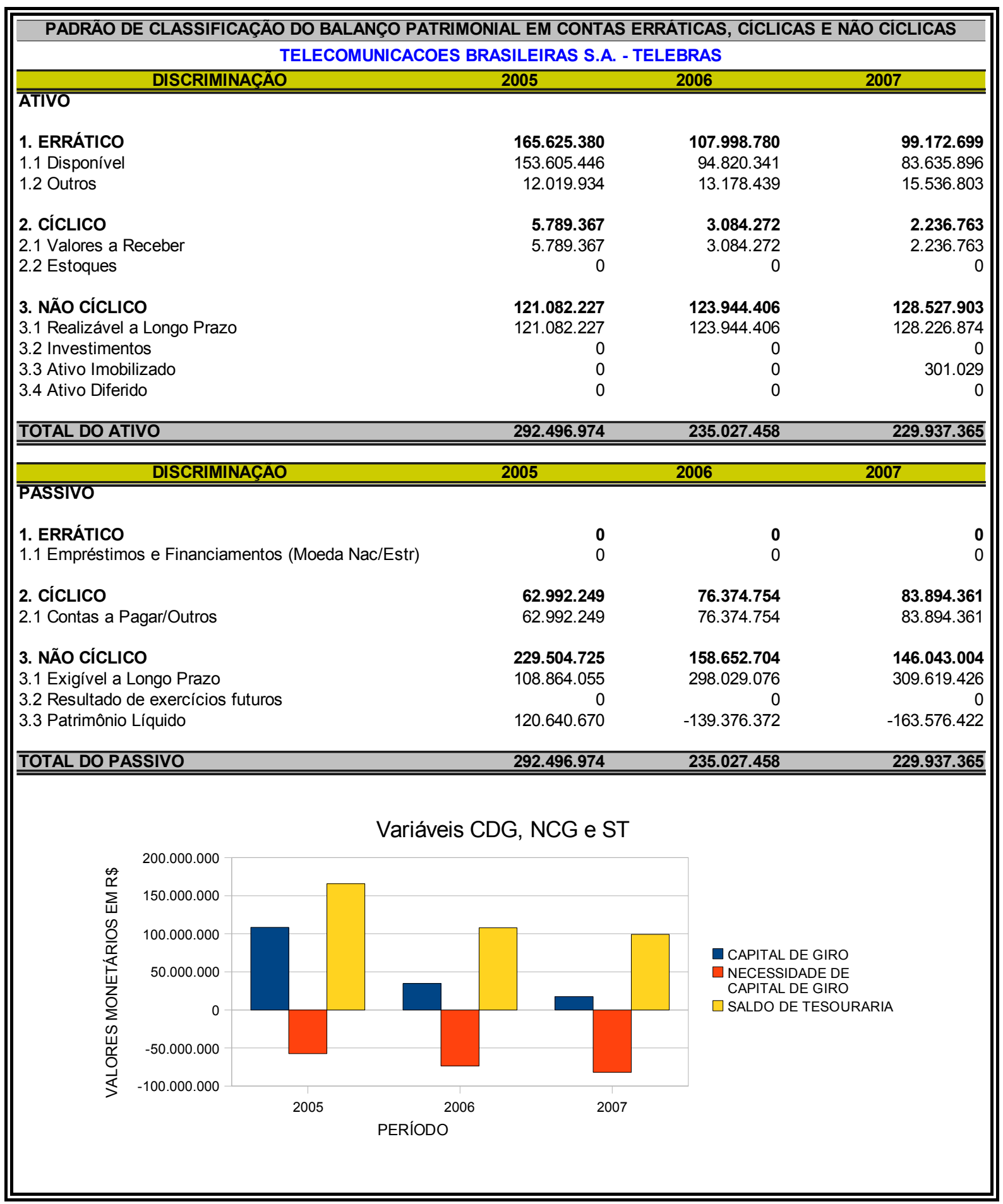

Gráfico 26. TELEBRAS

Fonte: adaptado do DEST( 2005, 2006 e 2007). 


\section{2 - Resultados das Empresas analisadas pelo Modelo Fleuriet.}

Apresentação das situações das empresas analisadas, conforme modelo Fleuriet, relativo aos resultados das empresas nos anos de 2005,2006 e 2007, conforme quadro 4.

\begin{tabular}{|c|c|c|c|c|c|c|c|c|c|c|c|c|}
\hline \multicolumn{13}{|c|}{ Estrutura e Situação Financeira } \\
\hline \multirow{2}{*}{ Empresas } & \multicolumn{4}{|c|}{ Ano 2005} & \multicolumn{4}{|c|}{ Ano 2006} & \multicolumn{4}{|c|}{ Ano 2007} \\
\hline & CDG & NCG & ST & Situação & CDG & NCG & ST & Situação & CDG & NCG & ST & Situação \\
\hline ATIVOS S.A & + & - & + & Excelente & + & - & + & Excelente & + & - & + & Excelente \\
\hline BB CARTÕES & + & - & + & Excelente & + & + & - & Insatisfatória & + & - & + & Excelente \\
\hline BB CORRETORA & + & - & + & Excelente & + & - & + & Excelente & + & - & + & Excelente \\
\hline BB TURISMO & + & - & + & Excelente & + & - & + & Excelente & - & - & + & Alto Risco \\
\hline CASEMG & - & - & + & Alto Risco & - & - & + & Alto Risco & - & $\cdot$ & + & Alto Risco \\
\hline $\mathrm{CMB}$ & + & + & + & Sólida & + & + & + & Sólida & + & + & + & Sólida \\
\hline CEAGESP & - & - & + & Alto Risco & - & - & + & Alto Risco & - & . & + & Alto Risco \\
\hline CEASAMINAS & + & - & + & Excelente & + & - & + & Excelente & + & - & + & Excelente \\
\hline COBRA & - & - & - & Muito Ruim & - & + & - & Péssima & - & - & $\cdot$ & Muito Ruim \\
\hline CODEBA & + & - & + & Excelente & + & - & + & Excelente & + & - & + & Excelente \\
\hline $\mathrm{CDC}$ & + & + & + & Sólida & + & - & + & Excelente & + & - & + & Excelente \\
\hline CODESA & + & - & + & Excelente & + & - & + & Excelente & - & - & + & Alto Risco \\
\hline CODESP & - & - & + & Alto Risco & - & - & + & Alto Risco & - & - & + & Alto Risco \\
\hline CODOMAR & + & - & + & Excelente & + & - & + & Excelente & + & - & + & Excelente \\
\hline CDP & + & - & + & Excelente & + & - & + & Excelente & + & - & + & Excelente \\
\hline CDRJ & - & - & + & Alto Risco & - & - & + & Alto Risco & - & - & + & Alto Risco \\
\hline CODERN & + & - & + & Excelente & + & - & + & Excelente & + &. & + & Excelente \\
\hline ECT & + & - & + & Excelente & + & - & + & Excelente & + &. & + & Excelente \\
\hline EMGEA & + & + & -1 & Insatisfatória & + & + & + & Sólida & + & + & $\cdot$ & Insatisfatória \\
\hline INFRAERO & + & + & + & Sólida & + & + & + & Sólida & + & . & + & Excelente \\
\hline EPE & + & + & + & Sólida & + & - & + & Excelente & + & - & + & Excelente \\
\hline DATAPREV & + & + & + & Sólida & + & + & + & Sólida & + & + & + & Sólida \\
\hline EMGEBRON & + & - & + & Excelente & + & - & + & Excelente & + & - & + & Excelente \\
\hline IMBEL & - & - & + & Alto Risco & - & - & + & Alto Risco & $\cdot$ & - & + & Alto Risco \\
\hline SERPRO & + & - & + & Excelente & + & + & + & Sólida & + & - & + & Excelente \\
\hline TELEBRAS & + & - & + & Excelente & + & - & + & Excelente & + & - & + & Excelente \\
\hline
\end{tabular}

Quadro 4. Situações Financeiras possíveis preconizada pelo modelo Fleuriet.

Fonte: adaptado de Marques e Braga (1995) 


\section{3 - Resultados Primários versus Necessidade de Capital de Giro.}

Apresentação dos resultados primários das empresas em relação ao modelo Fleuriet, relativo aos anos de 2005,2006 e 2007, conforme gráficos:

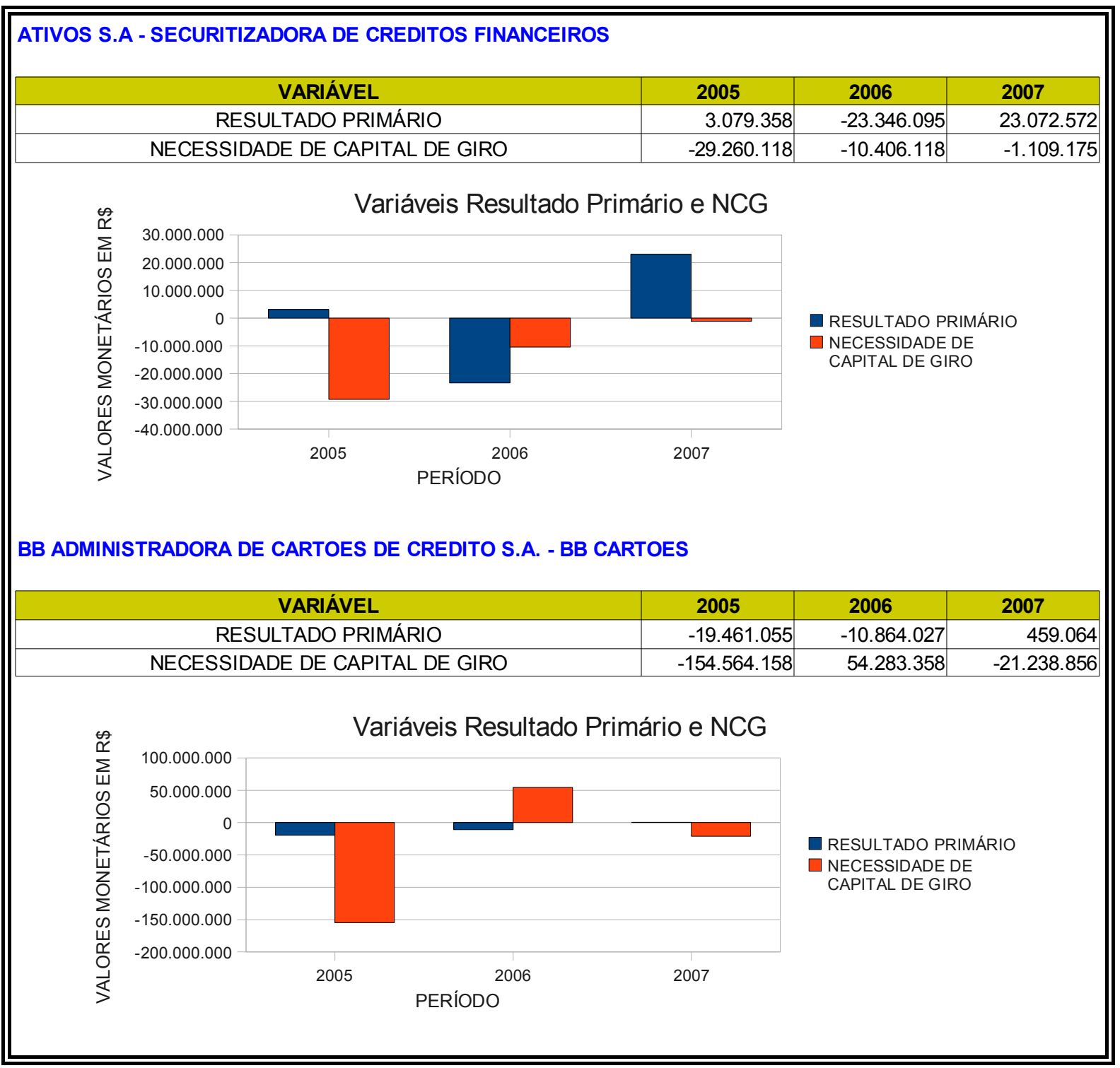


BB CORRETORA DE SEGUROS E ADM. DE BENS S.A. - BB CORRETORA

\begin{tabular}{||c|r|r|r||}
\hline VARIÁVEL & \multicolumn{1}{|c|}{$\mathbf{2 0 0 5}$} & \multicolumn{1}{|c|}{$\mathbf{2 0 0 6}$} & \multicolumn{1}{c|}{$\mathbf{2 0 0 7}$} \\
\hline RESULTADO PRIMÁRIO & -14.520 .418 & 13.895 .701 & 13.637 .895 \\
\hline NECESSIDADE DE CAPITAL DE GIRO & -63.987 .934 & -73.758 .486 & -85.582 .617 \\
\hline
\end{tabular}

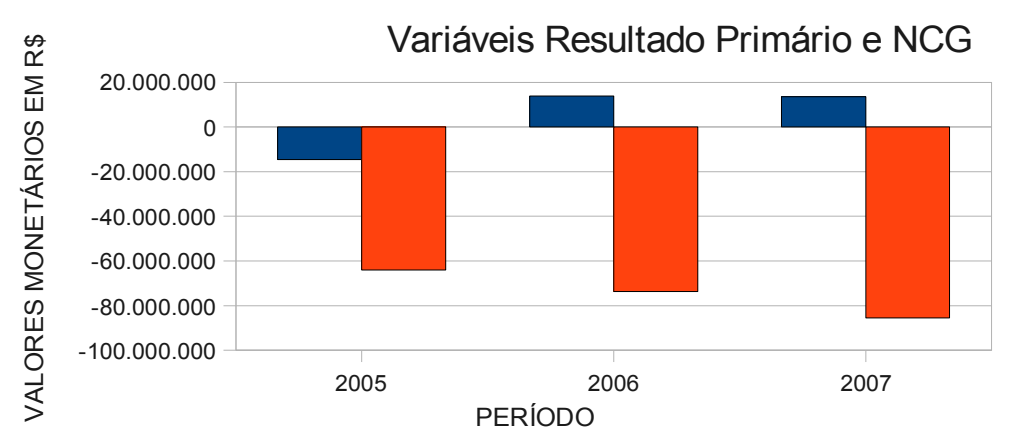

口ESULTADO PRIMÁRIO

$\square$ NECESSIDADE DE

CAPITAL DE GIRO

BBTUR - VIAGENS E TURISMO LTDA- BB TURISMO

\begin{tabular}{|c|c|r|r|}
\hline VARIÁVEL & $\mathbf{2 0 0 5}$ & \multicolumn{1}{|c|}{$\mathbf{2 0 0 6}$} & \multicolumn{1}{c|}{$\mathbf{2 0 0 7}$} \\
\hline RESULTADO PRIMÁRIO & -8.554 .669 & -6.603 .092 & -4.237 .839 \\
\hline NECESSIDADE DE CAPITAL DE GIRO & -7.199 .653 & -3.970 .461 & -18.404 .078 \\
\hline
\end{tabular}

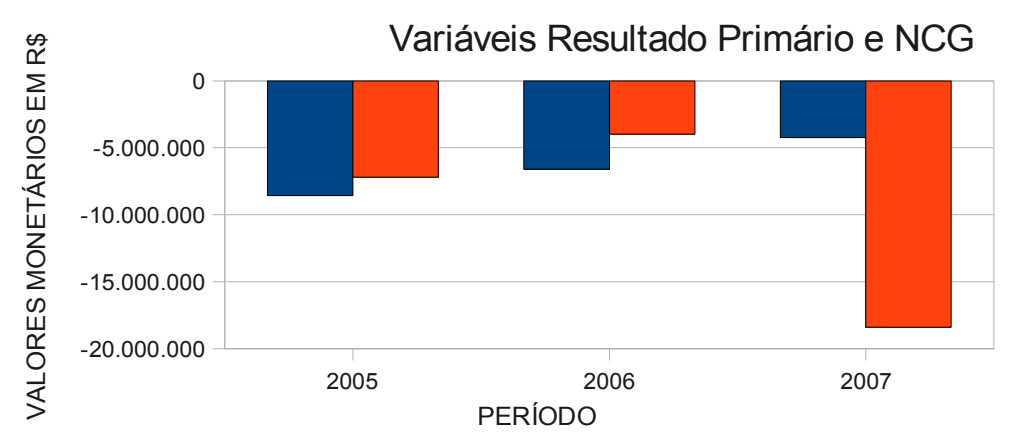

$\square$ RESULTADO PRIMÁRIO

$\square$ NECESSIDADE DE

CAPITAL DE GIRO

CIA DE ARMAZENS E SILOS DO ESTADO DE MINAS GERAIS - CASEMG

\begin{tabular}{||c|r|r|r||}
\hline VARIÁVEL & \multicolumn{1}{|c||}{$\mathbf{2 0 0 5}$} & \multicolumn{1}{|c|}{$\mathbf{2 0 0 6}$} & \multicolumn{1}{|c|}{$\mathbf{2 0 0 7}$} \\
\hline RESULTADO PRIMÁRIO & 779.071 & -1.290 .762 & -596.078 \\
\hline NECESSIDADE DE CAPITAL DE GIRO & -3.341 .370 & -1.332 .167 & -1.565 .310 \\
\hline
\end{tabular}

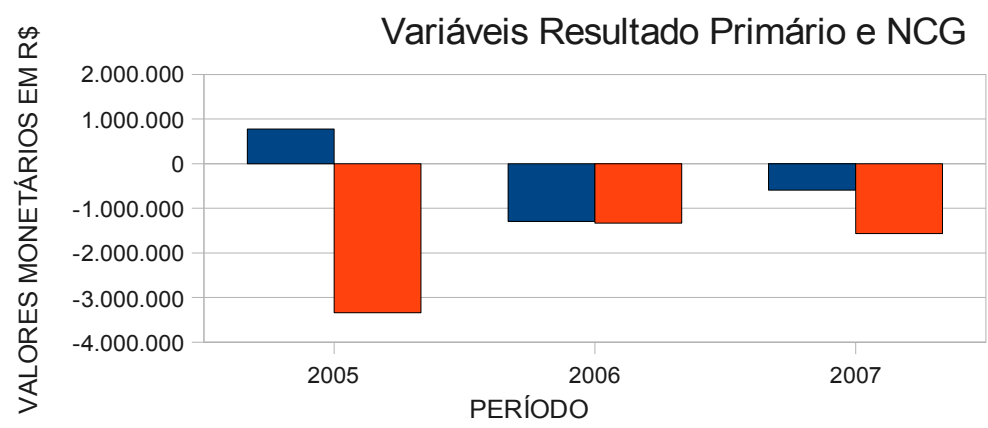

RESULTADO PRIMÁRIO

$\square$ NECESSIDADE DE

CAPITAL DE GIRO 
CASA DA MOEDA DO BRASIL - CMB

\begin{tabular}{|c|r|r|r|}
\hline VARIÁVEL & \multicolumn{1}{|c|}{$\mathbf{2 0 0 5}$} & \multicolumn{1}{c|}{$\mathbf{2 0 0 6}$} & \multicolumn{1}{c|}{$\mathbf{2 0 0 7}$} \\
\hline RESULTADO PRIMÁRIO & 6.223 .351 & -32.866 .979 & 11.275 .893 \\
\hline NECESSIDADE DE CAPITAL DE GIRO & 71.348 .472 & 93.720 .213 & 88.014 .180 \\
\hline
\end{tabular}

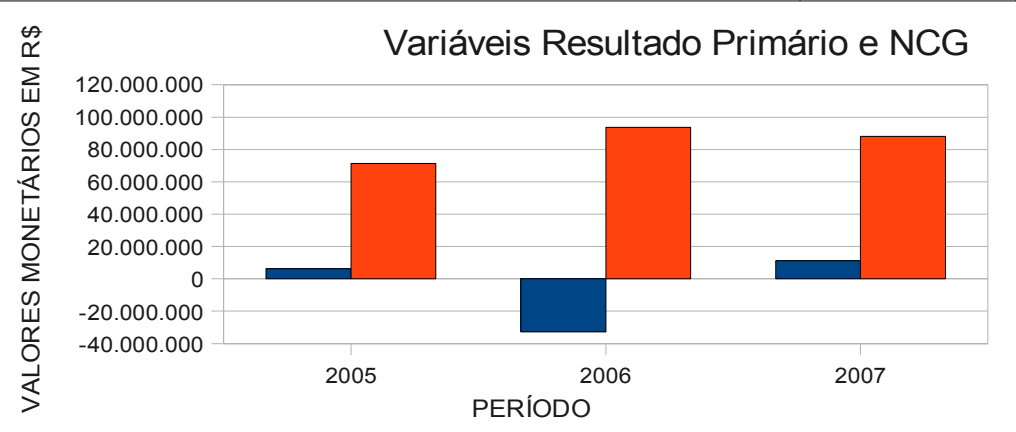

口ESULTADO PRIMÁRIO

$\square$ NECESSIDADE DE
CAPITAL DE GIRO

PERÍODO

CEAGESP - CIA DE ENTREPOSTOS E ARMAZENS DE SÃo PAULO

\begin{tabular}{|c|r|r|r||}
\hline VARIÁVEL & \multicolumn{1}{|c|}{$\mathbf{2 0 0 5}$} & \multicolumn{1}{|c|}{$\mathbf{2 0 0 6}$} & \multicolumn{1}{|c|}{2007} \\
\hline RESULTADO PRIMÁRIO & 1.327 .754 & 1.001 .402 & -643.992 \\
\hline NECESSIDADE DE CAPITAL DE GIRO & -42.697 .704 & -18.243 .610 & -26.936 .522 \\
\hline
\end{tabular}

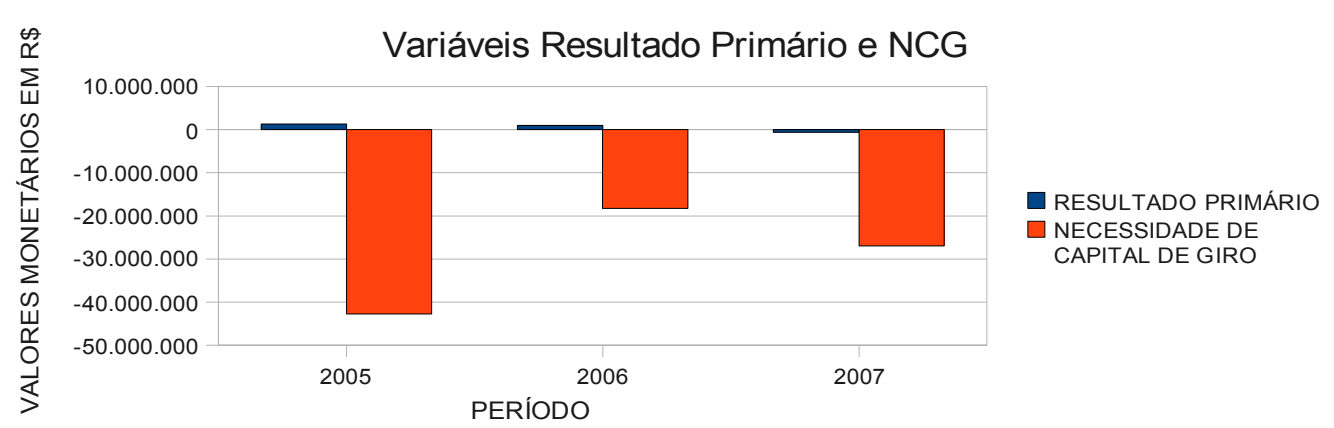

CENTRAIS DE ABASTECIMENTO DE MINAS GERAIS- CEASAMINAS

\begin{tabular}{||c|r|r|r||}
\hline VARIÁVEL & \multicolumn{1}{|c|}{$\mathbf{2 0 0 5}$} & \multicolumn{1}{c|}{$\mathbf{2 0 0 6}$} & \multicolumn{1}{c|}{$\mathbf{2 0 0 7}$} \\
\hline RESULTADO PRIMÁRIO & 219.068 & -7.337 .918 & 1.261 .659 \\
\hline NECESSIDADE DE CAPITAL DE GIRO & -3.061 .842 & -535.089 & -376.774 \\
\hline
\end{tabular}

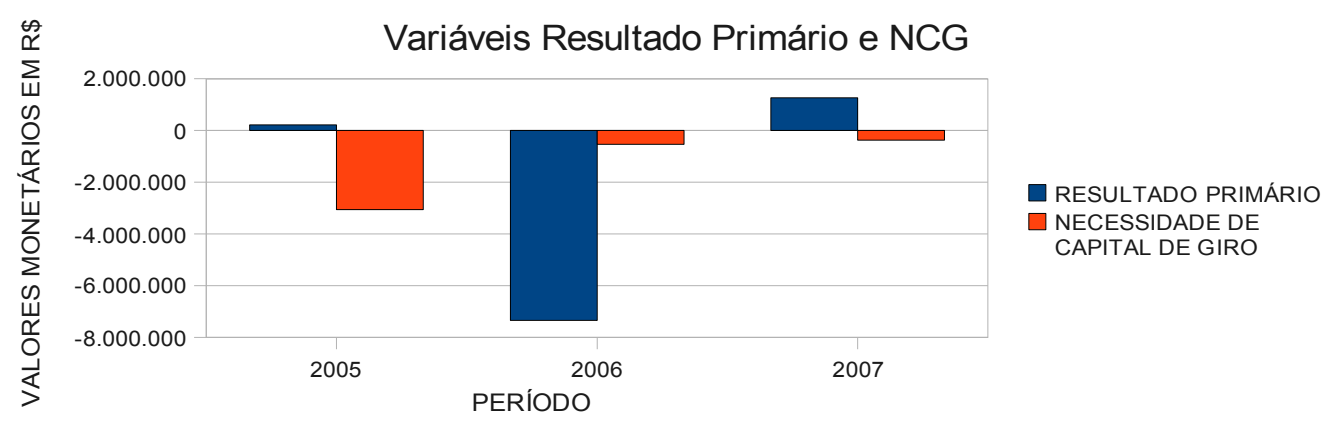




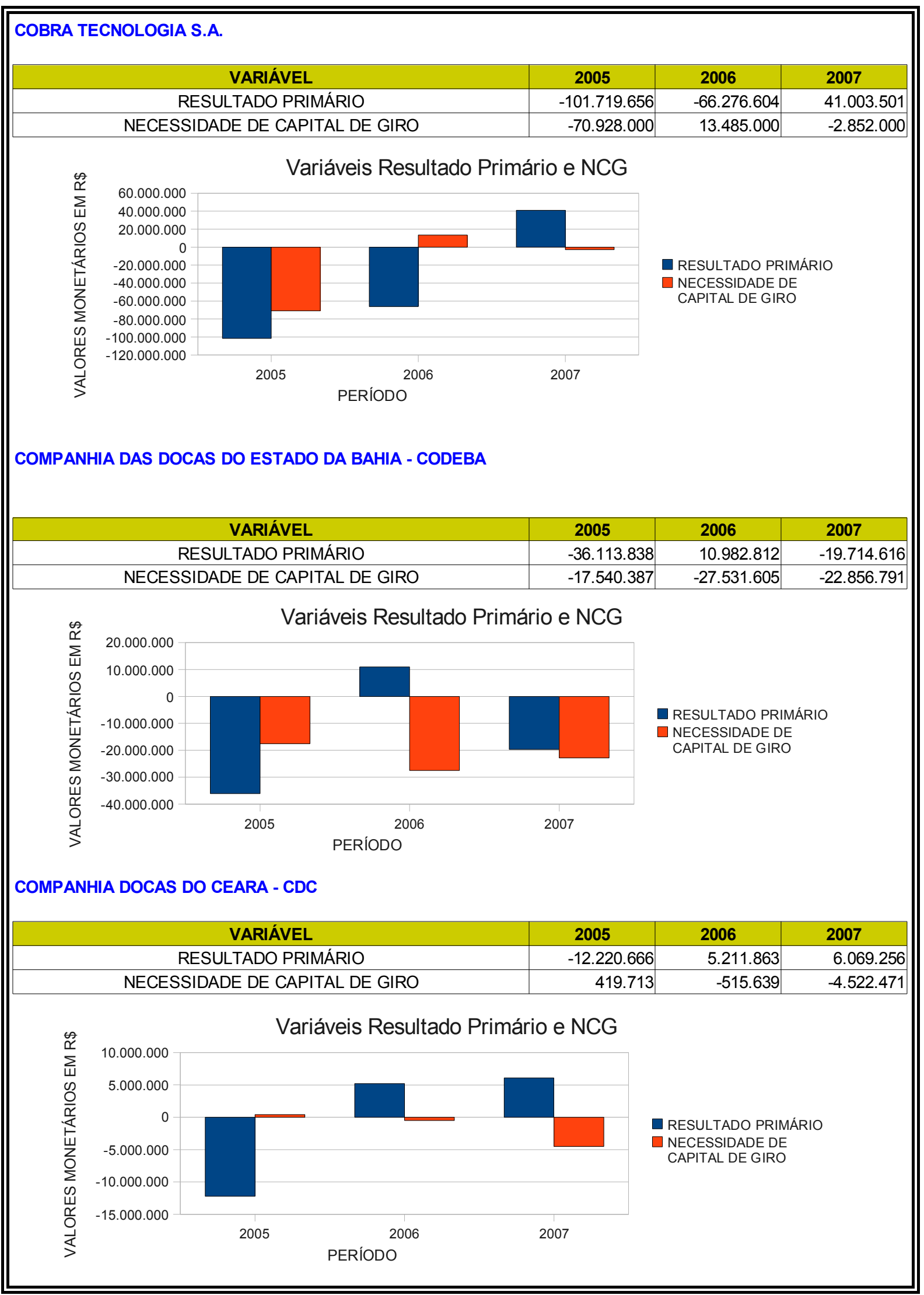




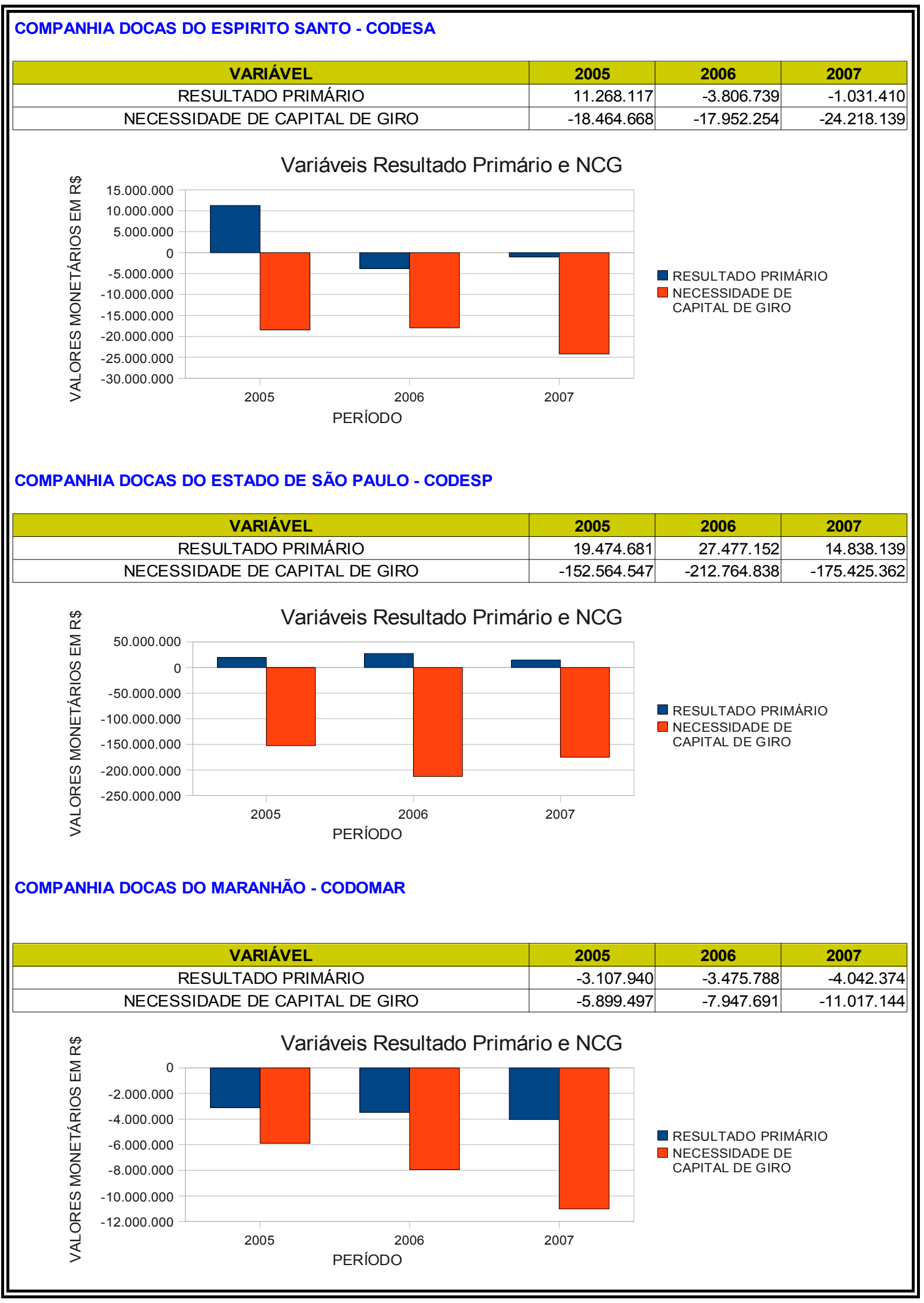




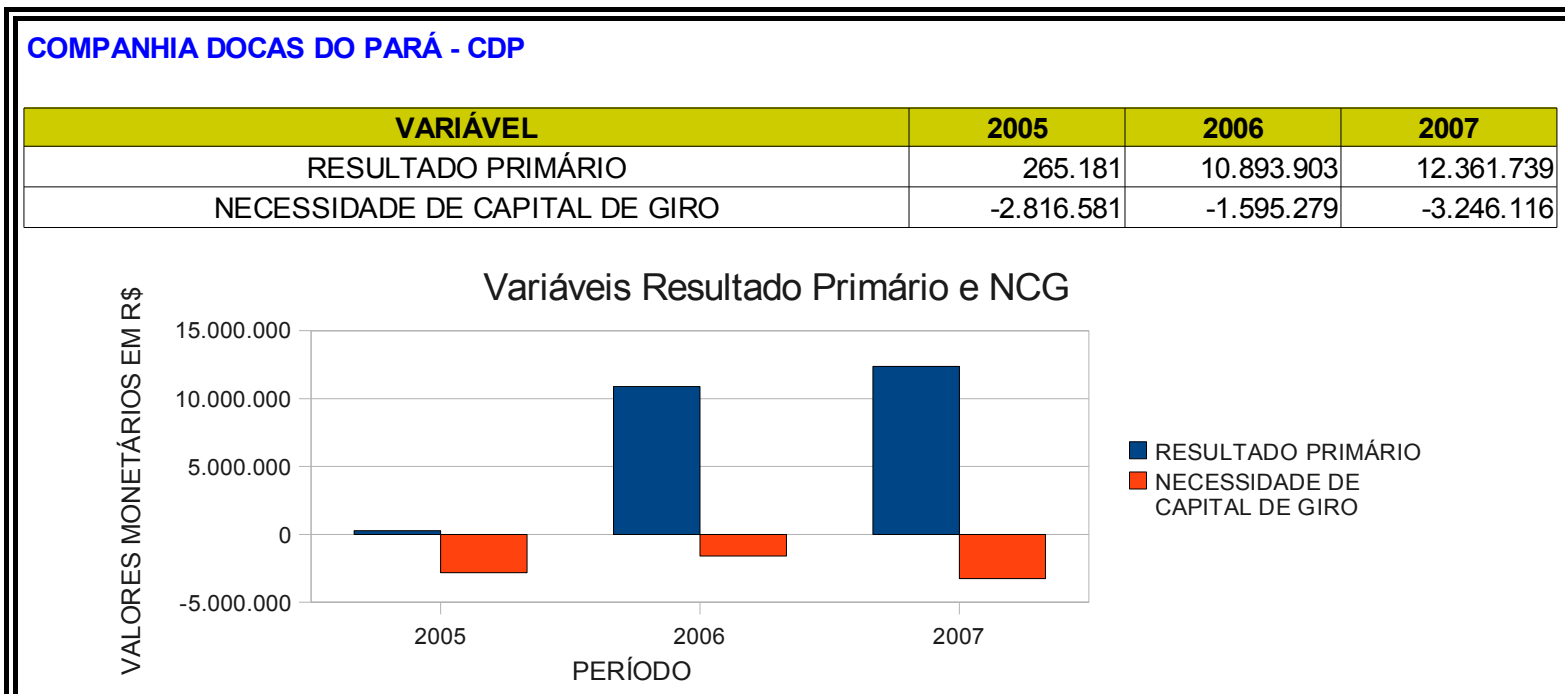

COMPANHIA DOCAS DO RIO DE JANEIRO - CDRJ

\begin{tabular}{|c|r|r|r|}
\hline VARIÁVEL & \multicolumn{1}{|c|}{$\mathbf{2 0 0 5}$} & \multicolumn{1}{c|}{$\mathbf{2 0 0 6}$} & \multicolumn{1}{c|}{$\mathbf{2 0 0 7}$} \\
\hline RESULTADO PRIMÁRIO & -4.795 .694 & 258.091 & 79.231 .961 \\
\hline NECESSIDADE DE CAPITAL DE GIRO & -150.060 .750 & -187.833 .139 & -239.750 .466 \\
\hline
\end{tabular}

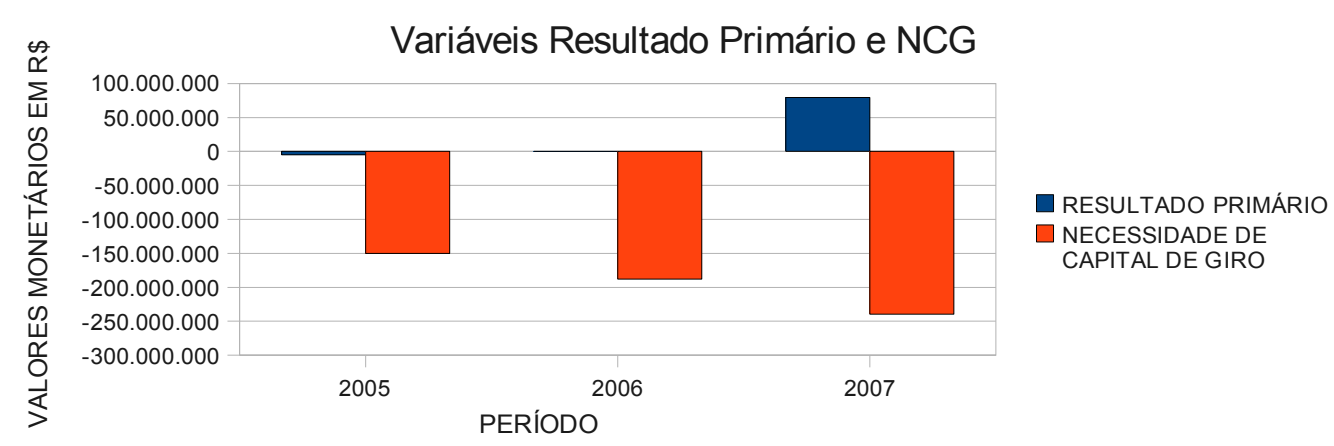

COMPANHIA DOCAS DO RIO GRANDE DO NORTE - CODERN

\begin{tabular}{|c|r|r|r|}
\hline VARIÁVEL & \multicolumn{1}{|c|}{$\mathbf{2 0 0 5}$} & $\mathbf{2 0 0 6}$ & $\mathbf{2 0 0 7}$ \\
\hline RESULTADO PRIMÁRIO & 1.982 .756 & 1.935 .221 & -3.660 .135 \\
\hline NECESSIDADE DE CAPITAL DE GIRO & -6.308 .892 & -3.758 .175 & -4.545 .673 \\
\hline
\end{tabular}

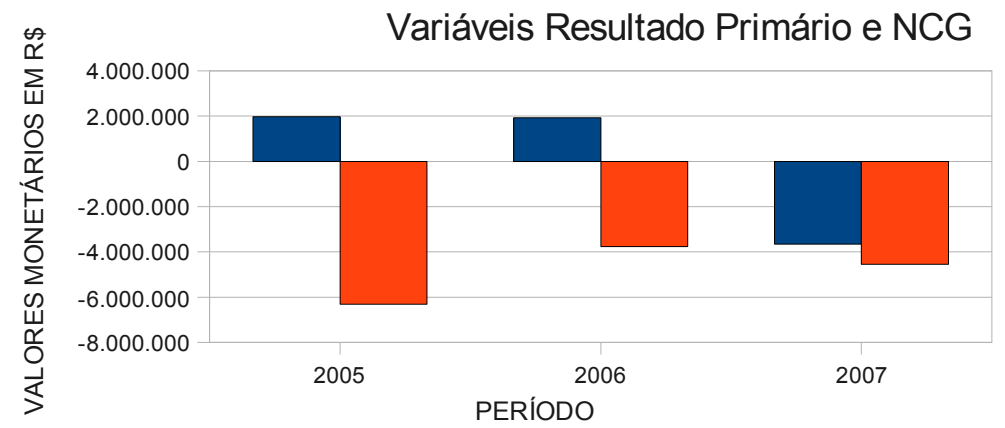

RESULTADO PRIMÁRIO

$\square$ NECESSIDADE DE CAPITAL DE GIRO 


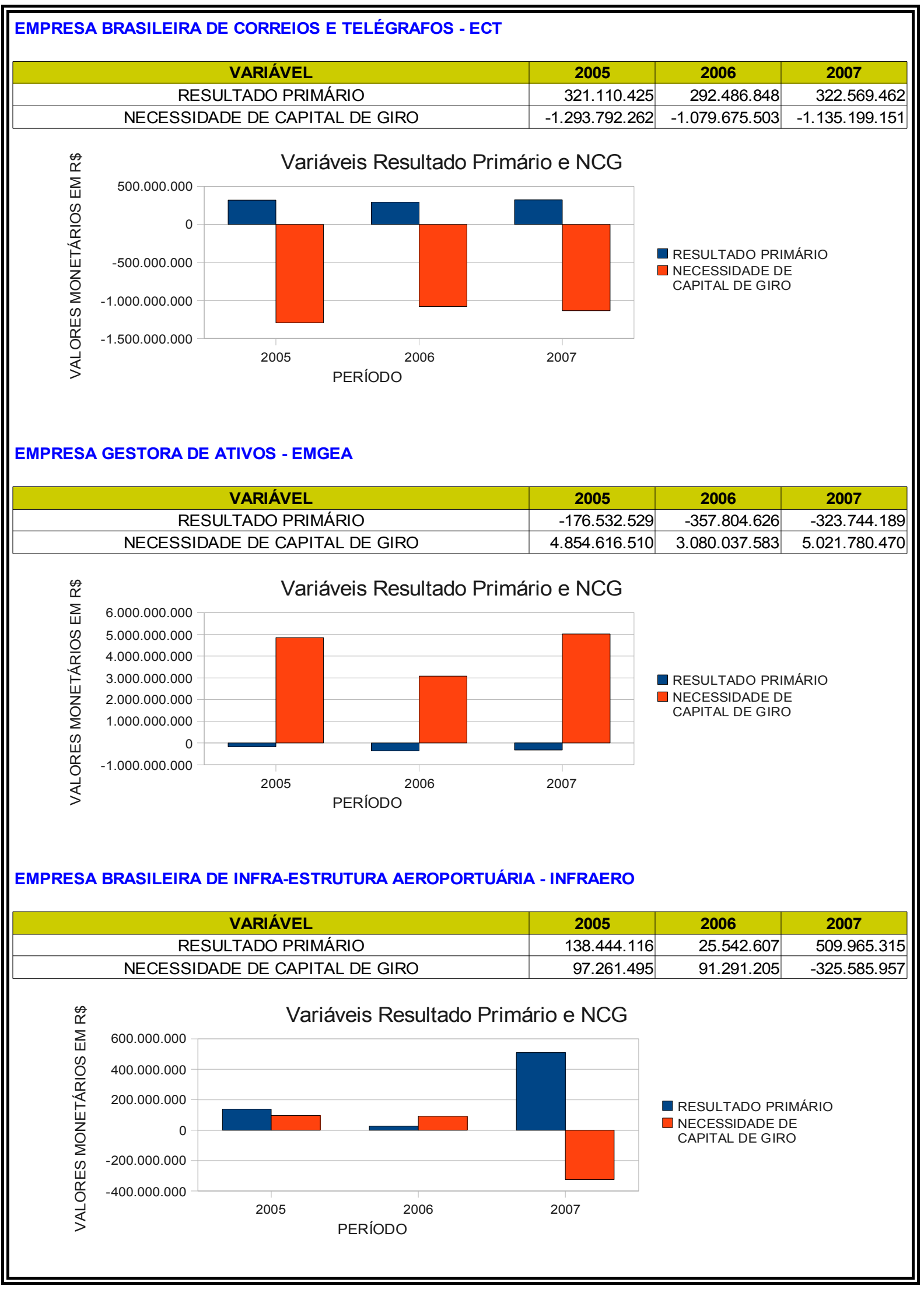




\begin{tabular}{|c|c|c|c|}
\hline \multicolumn{4}{|l|}{ EMPRESA DE PESQUISA ENERGÉTICA - EPE } \\
\hline VARIÁVEL & 2005 & 2006 & 2007 \\
\hline RESULTADO PRIMÁRIO & 7.366 .886 & -4.654 .872 & 11.304 .585 \\
\hline NECESSIDADE DE CAPITAL DE GIRO & 116.873 & -72.768 .174 & -72.818 .692 \\
\hline
\end{tabular}

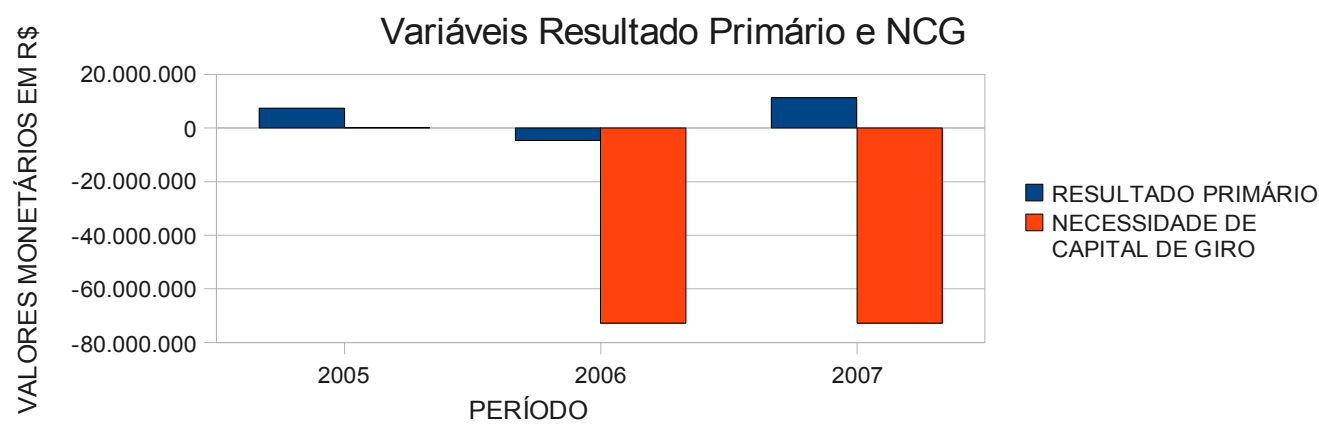

EMPRESA DE TECNOLOGIA E INFORMAÇÕES DA PREV. SOCIAL - DATAPREV

\begin{tabular}{|c|r|r|r||}
\hline VARIÁVEL & \multicolumn{1}{|c|}{$\mathbf{2 0 0 5}$} & $\mathbf{2}$ & $\mathbf{2 0 0 6}$ \\
\hline RESULTADO PRIMÁRIO & 6.190 .116 & 45.283 .015 & -47.945 .545 \\
\hline NECESSIDADE DE CAPITAL DE GIRO & 175.185 .218 & 196.740 .635 & 282.597 .385 \\
\hline
\end{tabular}

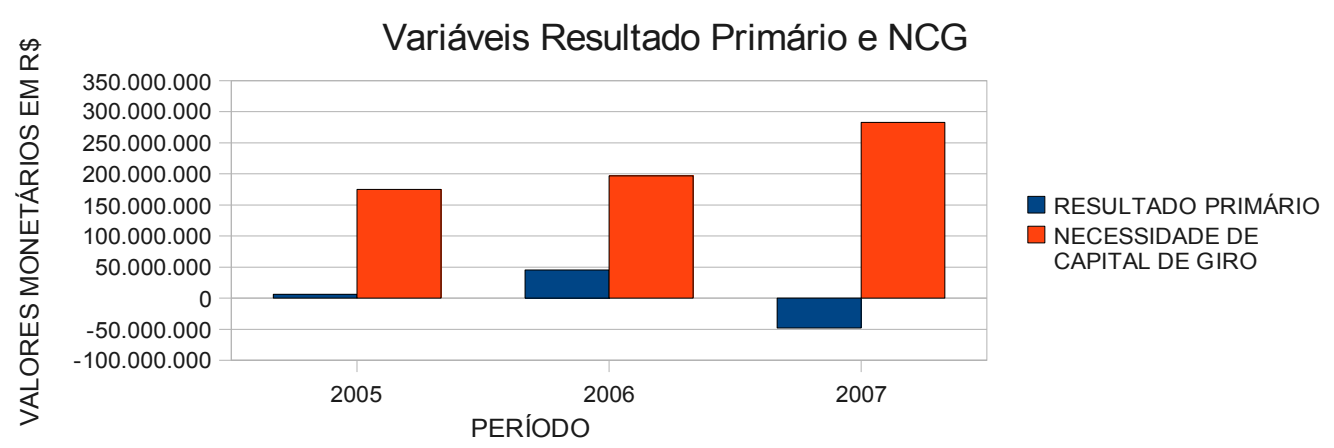

EMPRESA GERENCIAL DE PROJETOS NAVAIS - EMGEPRON

\begin{tabular}{|c|r|r|r||}
\hline VARIÁVEL & \multicolumn{1}{|c|}{$\mathbf{2 0 0 5}$} & $\mathbf{2 0 0 6}$ & $\mathbf{2 0 0 7}$ \\
\hline RESULTADO PRIMÁRIO & 35.228 .274 & -5.272 .994 & 50.934 .504 \\
\hline NECESSIDADE DE CAPITAL DE GIRO & -50.360 .953 & -73.874 .317 & -82.247 .109 \\
\hline
\end{tabular}

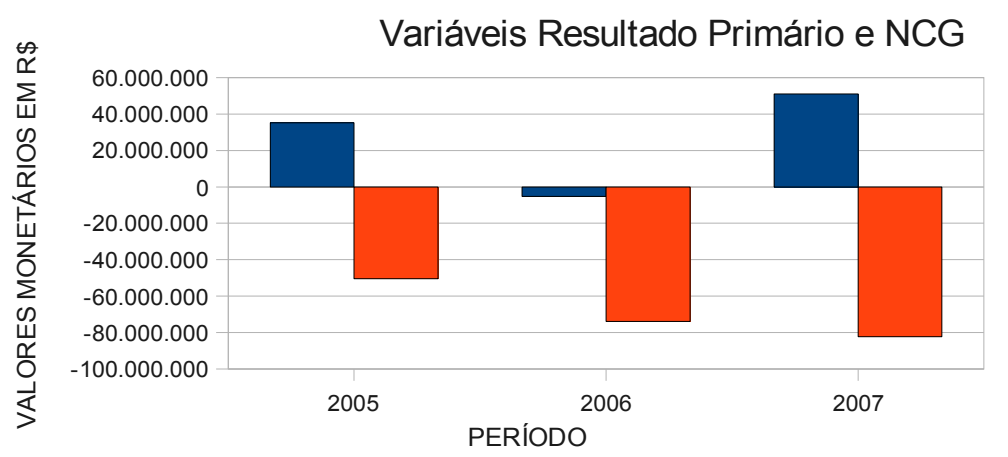

RESULTADO PRIMÁRIO

NECESSIDADE DE

CAPITAL DE GIRO

PERÍODO 


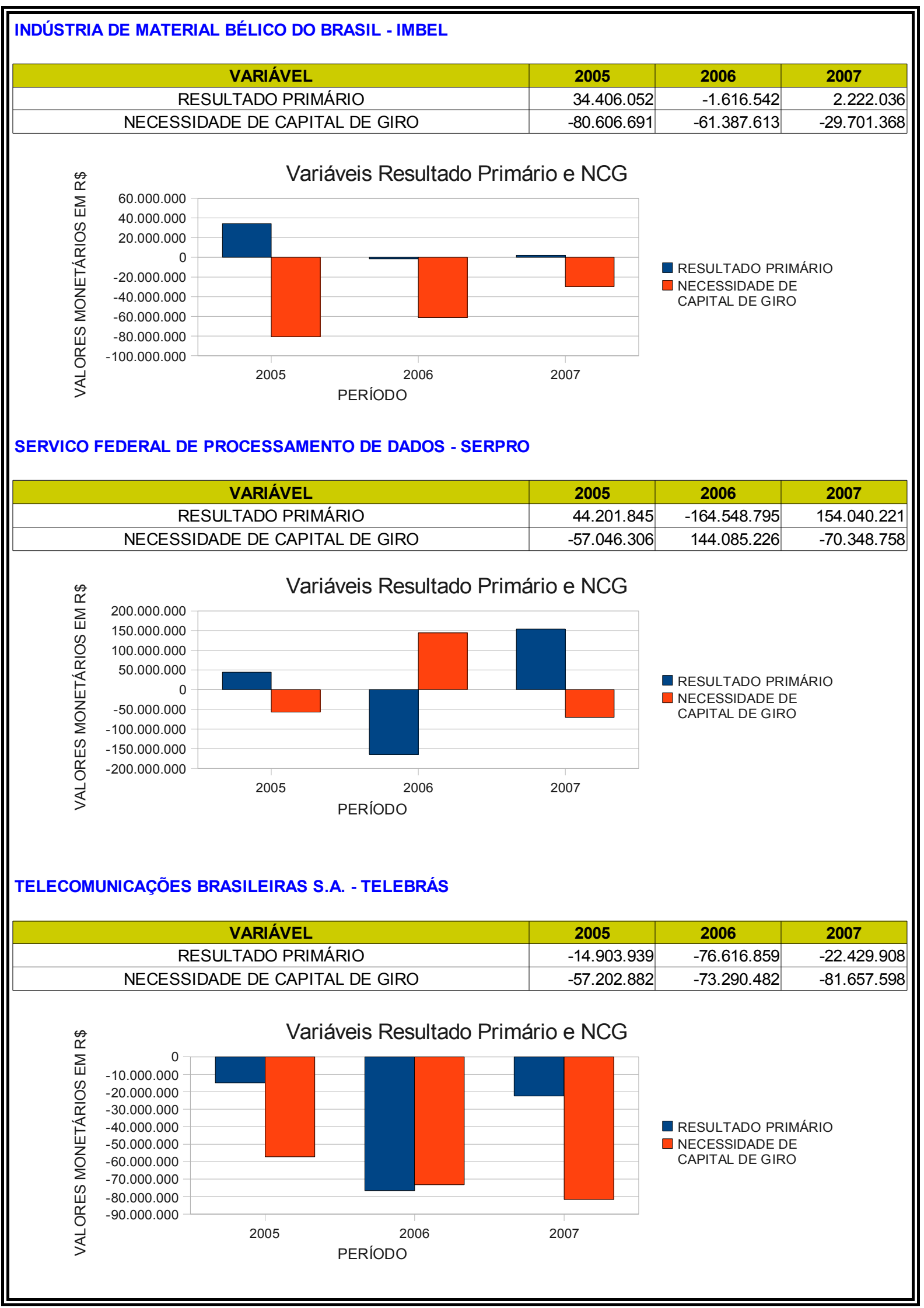




\section{5. - CONCLUSÃO}

O propósito deste estudo foi demonstrar que é possível conhecer a situação financeira de uma empresa, com a aplicação do modelo Fleuriet, a partir de suas demonstrações contábeis. A interpretação dos resultados desta pesquisa e todo o desenvolvimento por ela acarretado autorizam a esta monografia explicar algumas conclusões de ordem conceitual e empírica,dentre as quais se destacam:

$>$ na revisão da literatura sobre o tema pesquisa, encontraram-se várias referências nacionais e estrangeiras sobre a análise tradicional composta pelas análises:vertical e horizontal, análise através de índices, prazos médios e ciclos. Todavia verificou-se uma limitação de referências sobre a análise dinâmica consagrada através do Modelo Fleuriet;

$>$ a maioria dos autores recomendam que a análise vertical e horizontal devem ser interpretadas em conjunto com a análise através de índices. Porém, quando o foco da análise são os indicadores financeiros é de vital importância a realização da análise dinâmica. A análise dinâmica visa garantir a correta interpretação da situação financeira da empresa,corrigindo as distorções apresentadas pela análise através de índices, que são em sua essência índices estáticos e

verificou-se ainda que as técnicas de análise financeira, por meio do Modelo Fleuriet trazem em seu bojo um conjunto de informações relevantes sobre as empresas foco da pesquisa, não atendendo a diversos públicos de interesse, tais como: acionista, STN, empregados, DEST, TCU, bancos, e vários outros segmentos da sociedade.

O modelo descrito neste estudo auxilia o gestor publico na avaliação da liquidez e solvência das empresas, e na identificação do tipo de estrutura financeira utilizada e/ou característica do segmento classificado como Demais SPE, bem como a verificação de suas 
tendências relativas.

Registra-se que serve de instrumento suplementar à análise de liquidez tradicional, às vezes fornecendo indicativos antecipados de deterioração ou recuperação financeira da empresa. O montante do fluxo de caixa operacional significa, em verdade, uma medida aproximada do item caixa gerado das atividades operacionais. implementação do nível desejado de operação.

Os resultados obtidos permitiram uma comparação da magnitude do investimento operacional em giro mantido pelas empresas para a implementação do do nível desejado de operações, e o grau de endividamento(saldo de tesouraria) praticado. O retorno e liquidez também foi verificado para essa reduzida amostra. Não foi identificada, entretanto, a tendência desses elementos, o que somente seria possível com o emprego de um horizonte de tempo mais dilatado.

Outros estudos poderiam adotar amostras mais significativas e definir tendências setoriais específicas. 


\section{REFERÊNCIAS}

ANDRADE, M. M. Introdução à Metodologia do Trabalho Científico: elaboração de trabalhos na graduação. São Paulo: Atlas, 2003.174p.

ANDRADE,E.L. Introdução à pesquisa operacional:métodos e modelos para análise de decisões. 3 ed. Rio de Janeiro: Qualitymark, 2002.163p.

ANDRÉ, M. A. O Desempenho de Empresa Pública no Setor Metroviário. Revista de Administração, São Paulo, abril/junho. 1990. p.34-46.

ASSAF NET0,A.;SILVA, C.A.T. Administração do Capital de Giro, São Paulo; Atlas,2002.

BARROSO, Luís. Roberto. Fundamentos teóricos e filosóficos do novo Direito

Constitucional Brasileiro. (Pós-Modernidade, teoria crítica e pós-positivismo). Interesse Público, Sapucaia do Sul, v. 3, n. 11, jul./set. 2001. p. 42-73.

BRASIL. Constituição da República Federativa do Brasil (1988). Lex: legislação federal e marginalia, Brasília, 1988.

BRASIL. Decreto-Lei n ${ }^{\circ}$ 200, de 25 de fevereiro de 1967. Lex: coletânea de legislação: edição federal, Brasília, v.2, 1967. Suplemento.

BRASIL. Lei no 6.404, de 15 de dezembro 1979. Lex: coletânea de legislação: edição federal, Brasília, v.1, 1979. Suplemento.

Lei 11.647, de 24 de março de 2008. Lex: coletânea de legislação: edição federal, Brasília, v.1, 2008. Suplemento.

Lei $n^{0}$ 8.666, de 21 de junho de 1993. Lex: coletânea de legislação: edição federal, Brasília, v.1, 1993. Suplemento.

Lei $n^{\circ} 10.683$, de 13 de agosto de 2004. Lex: coletânea de legislação: edição federal, Brasília, v.1, 2004. Suplemento. 
Brasil. Ministério do Planejamento, Orçamento e Gestão. Relatório de Execução Orçamentária 2008. Departamento de Controle das Estatais, Brasília, 2008.

FLEURIET, M. A. Dinâmica Financeira das Empresas, um novo método de análise, orçamento e planejamento financeiro. 2A Ed., Belo Horizonte, Edições Fundação Dom Cabral e Consultoria Editorial Ltda., 1980.

FLEURIET, M.; KEHDY, R.; BLANC, G. O modelo Fleuriet: A Dinâmica Financeira das Empresas Brasileiras: Um Novo Método de Análise, Orçamento e Planejamento. Rio de Janeiro: Campus, 2003.

GALLINGER,G.W.;HEALEY,P.B., Liquidity Analysis and Management, Reading: Addinson-Weslwy, 1991.

GASKELL, G. Entrevistas individuais e grupais. IN Bauer, m. w.; Pesquisa qualitativa com texto, imagem e som: um manual prático. Petrópolis, RJ vozes, 2002. p. 64-88.

GIL, A. C. Como Elaborar Projetos de Pesquisa. 4 edição São Paulo: Atlas, 2002.p. 175.

H.G. Gestão Financeira das Empresas: um modelo dinâmico. 4.ed. Rio de Janeiro: Qualitymark, 2002.163p.

HEWLETT, Sylvia. Ann. Dilemas do Desenvolvimento. Rio de Janeiro, 1981, p. 15.

IUDÍCIBUS, Sérgio de. Análise de balanços. 7. ed. São Paulo: Atlas, 1998.

LOBATO, R. Q. Avaliação de Desempenho de Empresas Estatais no Novo Contexto de Retomada do Desenvolvimento. Monografia do Prêmio DEST/MP. Brasília. 2007.

MOREIRA. N. A Lei de Responsabilidade Fiscal e seus princípios jurídicos. Revista de Direito Administrativo, Rio de Janeiro, n. 221, jul./set. 2000. p. 71-93.

Neely, A. D. Measuring business performance: why, why and how. London: Economist Books, 1998. 
OLIVEIRA, A. C. M; BRAGA. R. Influência do modelo Fleuriet: Geração de valor econômico agregado das empresas do setor varejista e de transportes. Universidade de São Paulo, 2002. p. 1-15.

PADOVEZE, C. L. Contabilidade Gerencial: um enfoque em sistema de informação contábil. 3. ed. São Paulo:Atlas, 2000.

PENNA, J. O.M. Eficiência Econômica. Rio de Janeiro, Carta Mensal, Ano XXVIII - no 332, Nov. 1982. p. 8.

REES, R. A economia da empresa pública. Zahar editores, Rio de Janeiro, 1979.

ROSS,S.A.;WESTERFIELD,R.W.;JAFFE,J.F. Administração Financeira,São Paulo:Atlas, 1995.

SANTOS, A. R. Metodologia Científica: a construção do conhecimento. São Paulo:DP\&A, 1999. p.28-29.

TORRES, Ricardo Lobo. O Tribunal de Contas e o controle da legalidade, economicidade e legitimidade. Revista do Tribunal de Contas do Estado do Rio de Janeiro, Rio de Janeiro, v. 13, n. 22, jul. 1991. p. 37-44.

VERGARA, S. C. Começando a definir a metodologia. In: Projetos e relatórios de pesquisa em administração. 3 ed. São Paulo: Atlas, 2000. cap. 4. 